https://doi.org/10.11646/zootaxa.4565.3.1

http://zoobank.org/urn:lsid:zoobank.org:pub:34B92688-DF7B-49D7-8359-ED3DC3E7B225

\title{
A new species of Bothrops (Serpentes: Viperidae: Crotalinae) from Pampas del Heath, southeastern Peru, with comments on the systematics of the Bothrops neuwiedi species group
}

\author{
PAOLA A. CARRASCO ${ }^{1,2,10}$, FELIPE G. GRAZZIOTIN ${ }^{3}$, ROY SANTA CRUZ FARFÁN ${ }^{4}$, \\ CLAUDIA KOCH ${ }^{5}$, JOSÉ ANTONIO OCHOA ${ }^{6,7,8}$, GUSTAVO J. SCROCCHI ${ }^{9}$, \\ GERARDO C. LEYNAUD ${ }^{1,2}$ \& JUAN C. CHAPARRO ${ }^{6,7}$ \\ ${ }^{1}$ Universidad Nacional de Córdoba, Facultad de Ciencias Exactas, Físicas y Naturales, Centro de Zoología Aplicada, Rondeau 798, \\ Córdoba 5000, Argentina. \\ ${ }^{2}$ Consejo Nacional de Investigaciones Científicas y Técnicas (CONICET), Instituto de Diversidad y Ecología Animal (IDEA), Ron- \\ deau 798, Córdoba 5000, Argentina. \\ ${ }^{3}$ Laboratório de Coleções Zoológicas, Instituto Butantan, Avenida Vital Brasil, 1500, São Paulo, SP, Brazil. \\ ${ }^{4}$ Área de Herpetología, Museo de Historia Natural de la Universidad Nacional de San Agustín, 051, Arequipa 04000, Perú. \\ ${ }^{5}$ Zoologisches Forschungsmuseum Alexander Koenig, Adenauerallee 160, 53113 Bonn, Germany. \\ ${ }^{6}$ Museo de Biodiversidad del Perú, Urbanización Mariscal Gamarra A-61, Zona 2, Cusco, Perú. \\ ${ }^{7}$ Museo de Historia Natural de la Universidad Nacional de San Antonio Abad del Cusco, Paraninfo Universitario (Plaza de Armas s/ \\ n), Cusco, Perú. \\ ${ }^{8}$ Frankfurt Zoological Society-Perú, Residencial Huancaro, Los Cipreses H-21, Santiago, Cusco, Perú. \\ ${ }^{9}$ UEL-CONICET and Fundación Miguel Lillo, Miguel Lillo 251, San Miguel de Tucumán, Tucumán, Argentina \\ ${ }^{10}$ Corresponding author. E-mail: ammodytoides@gmail.com
}

\begin{abstract}
We describe a new species of pitviper of the genus Bothrops from the Peruvian Pampas del Heath, in the Bahuaja-Sonene National Park. Pampas del Heath is an area of seasonally flooded savannas and a northwestern extension of the Gran Chaco Boliviano-Paraguayo. The new species is easily distinguished from its congeners by the exclusive combination of dorsal color pattern of body consisting of small C-shaped blotches, postocular stripe originating posteriorly to the eye, covering posterior supralabials, dorsum of the head with paired markings arranged symmetrically, venter cream heavily speckled with brown, prelacunal scale discrete in contact with second supralabial, three to five prefoveals, subfoveal single usually present, postfoveals absent to two, canthals two, seven intersupraoculars, one or two suboculars, two or three postoculars, seven or eight supralabials, nine to eleven infralabials, 26-27 interrictals, 23-25 middorsal scales, 172 ventrals in the female and 169-173 in males, 45 subcaudals in the female and 50 in males. We performed separate and combined phylogenetic analyses based on morphology and five mitochondrial genes and recovered the new species as a member of the Bothrops neuwiedi species group. All lineages of this clade inhabit the South American dry diagonal. This novel species of pitviper increases the known diversity of the genus Bothrops and adds to the number of described taxa from the unique and scarcely known ecosystem of Pampas del Heath.
\end{abstract}

Key words: Bothrops mattogrossensis, species delimitation, molecular phylogeny, morphological characters, total evidence

\section{Introduction}

The pitvipers of the genus Bothrops Wagler 1824, which includes 45 species (Uetz \& Hošek 2018), inhabit most of the ecoregions along South America. Some of these ecoregions are included in the area known as the South American dry diagonal, which extends through the phytogeographical domains of the Caatinga, Cerrado and Chaco, from northeastern Brazil to the center of Argentina. The diagonal is a belt of seasonally dry forests, including other types of vegetation such as wet forests and savannas, located between the Amazon and Atlantic rain 
forests (Vanzolini 1963; Prado \& Gibbs 1993; Oliveira-Filho \& Ratter 2002; Pennington et al. 2006; Werneck 2011). Most species of Bothrops inhabiting the dry diagonal belong to the B. alternatus Duméril, Bibron \& Duméril 1854 and B. neuwiedi Wagler 1824 species groups (Campbell \& Lamar 2004; Silva 2004; Silva \& Rodrigues 2008; Nogueira et al. 2010; Fenker et al. 2014; Machado et al. 2014; Araújo 2015). Herein, we describe a new species of the Bothrops neuwiedi group from the Pampas del Heath in the Bahuaja-Sonene National Park, a natural protected area in southeastern Peru, near the Bolivian border.

The Bothrops neuwiedi group of species is distributed from northeastern Brazil to southern Argentina, through Bolivia, Peru, Paraguay and Uruguay, and includes: the former species, which inhabits the mountains in the southeast Brazilian coast; B. diporus Cope 1862 and B. mattogrossensis Amaral 1925, which occur mainly in the Chaco and Pantanal; B. erythromelas Amaral 1923, restricted to the Caatinga; B. lutzi Miranda-Ribeiro 1915, B. marmoratus Silva \& Rodrigues 2008 and B. pauloensis Amaral 1925, which occur mainly in the Cerrado; and $B$. pubescens Cope 1870, which inhabit the Uruguayan savannas of southern Brazil and Uruguay (Silva 2004; Silva \& Rodrigues 2008; Machado et al. 2014). The Peruvian part of Pampas del Heath, where the new species was found, is an area of 6,549 ha of humid tropical savanna or seasonally flooded grassland, interspersed with small woodlots and areas of palm swamp (Williams et al. 2012); it is a northwestern extension of the Gran Chaco of Bolivia and Paraguay and a natural limit with the surrounding Amazonia. The area is a National Sanctuary protected since 1983, and currently is part of the Bahuaja-Sonene National Park, created in 1996. The ecosystem of these "pampas" of Peru remains largely unknown, although a few biological surveys have demonstrated the singularity of the area and the presence of many potential new species of amphibians and reptiles (Roberto Gutiérrez pers. comm.).

Shortly before the foundation of the sanctuary, Hoffmann et al. (1976) reported the presence of two mammal species, the marsh deer (Blastoceros dichotomus Illiger 1815) and the maned wolf (Chrysocyon brachyurus Illiger 1815), in Pampas del Heath, which was the first evidence of these species in Peruvian territory. In addition, Graham et al. (1980) reported the first records for Peru of 17 species of birds from the same region. A multidisciplinary survey, performed in Pampas del Heath in 1996 as a Rapid Assessment Program (RAS), reported new records for Peru of birds, mammals, amphibians and reptiles (Stotz et al. 2002; Cadle et al. 2002; Luna et al. 2002). In this study, we describe a newly discovered and distinct population of pitvipers of the genus Bothrops from Pampas del Heath, and use phylogenetic analyses of morphological and molecular characters to assess its systematic position as well as its taxonomic status. We recovered the new species as a member of the Bothrops neuwiedi group on the basis of both morphological and molecular evidence.

\section{Material and methods}

Material and collection procedures. We conducted field-work as a part of the biological monitoring program of the Bahuaja-Sonene National Park, which has been carried out every year since 2013. We euthanized the specimens with Halatal, we fixed them in formalin solution, and preserved them in ethanol $70 \%$. We took tissues samples of muscle and preserved them in ethanol $96 \%$ for subsequent molecular studies.

Specimens and morphological study. We collected three specimens during 2013 and 2015, which were preserved in the MUBI and MUSA. We examined a fourth specimen housed in the MUSM. Sex was determined by examination of the presence/absence of hemipenes through a ventral incision at the base of the tail. We considered adult specimens those with snout-vent lengths $\geq 500 \mathrm{~mm}$ (Hartmann et al. 2004; Barros et al. 2014). We took measurements for morphometric characters using a digital caliper to the nearest $0.01 \mathrm{~mm}$ and later all measurements were rounded to only one decimal. We used a stereoscope and digital images for morphological examinations. We recorded coloration through observation of live specimens, photographs, and examination of alcohol-preserved specimens. We examined the hemipenial morphology of two males (MUBI 14679, MUSA 4350). Hemipenes were everted and prepared for examination ex situ, following standard procedures (Pesantes 1994; Zaher 1999). In the description, a slash (/) is used for counts from left/right sides of the body. For comparative purpose, we examined a total of 534 specimens of Bothrops and related crotaline genera (Bothrocophias Gutberlet \& Campbell 2001, Porthidium Cope 1871, Cerrophidion Campbell \& Lamar 1992, Atropoides Werman 1992, Bothriechis Peters 1859, Lachesis Daudin 1803 and Crotalus Linnaeus 1758) (Appendix I). The comparative material is housed in scientific collections whose institutional abbreviations are as listed in 
Sabaj (2016), except for MUBI (Museo de Biodiversidad del Perú, Cusco, Perú) and CZA (Centro de Zoología Aplicada, Córdoba, Argentina). We followed the taxonomy of Carrasco et al. (2012) and Silva \& Rodrigues (2008) for alpha and beta taxonomy adopted for the genus Bothrops and the B. neuwiedi group, respectively.

We recorded continuous and discrete characters from external morphology (most from scalation and coloration) and hemipenial morphology. Our definition of characters of external morphology followed or were adapted [*] from Carrasco et al. (2012), while others were modified from Silva \& Rodrigues (2008) [**] or defined in the present study [***]. Definition of characters of the hemipenis followed Pesantes (1989). We recorded the following morphological characters: scales between internasals***; loreals***; ventrals; subcaudals; intersupraoculars; scales contacting supraoculars; supralabials; infralabials; canthals; postcanthals; anterior intercanthals***; medial intercanthals; posterior intercanthals***; prefoveals; subfoveals; postfoveals; suboculars; postoculars; interoculabials between suboculars and $3^{\text {rd }}-4^{\text {th }}$ supralabials***; interoculabials between suboculars and $4^{\text {th }}$ supralabial; interoculabials between suboculars and $4^{\text {th }}-5^{\text {th }}$ supralabials***; sublacunals***; dorsocephalic scales from the snout to the neck, longitudinally***; interrictals; gulars; middorsal scales rows; distance between the eye and the anterior end of the head/length of the head; interorbital distance/maximum width of the head; internostril distance/width of the head; length of caudal spine/caudal length; postorbital stripe height (scored as number of scales at the level of $5^{\text {th }}-6^{\text {th }}$ supralabials); postorbital stripe length (scored as number of scales posteriorly to the rictus)***; supralabials encroached on by postorbital stripe; infralabials encroached on by postorbital stripe***; inferior/superior margins of mid-dorsolateral blotch**; height of mid-dorsolateral blotch**; minimum space between mid-dorsolateral blotches**; dorsolateral blotches***; length of hemipenial body/total hemipenial length; length of capitulum/length of hemipenial lobe; shape of internasals (rounded, oval)***; ventral markings (immaculate, heavily speckled on all the ventral region, heavily speckled on the lateroventral region, slightly speckled on the lateroventral region, very slightly speckled on the lateroventral region to almost immaculate) ${ }^{* * *}$; gular coloration (strongly pigmented, slightly pigmented, immaculate)***; ventral margin of postorbital stripe starts posterior, below, or anterior to the orbit; pair of parietal blotches on the head (absent, rounded, elongated posteriorly)***; pair of occipital blotches (elongated posteriorly beyond the neck, elongated posteriorly to the neck) ${ }^{* * *}$; superior portion of dorsolateral blotches (rectangular, subtriangular, rounded) ${ }^{* * *}$; markings on gulars (absent, diffused markings, conspicuous stripes); distinct white spots on posterior infralabials and gulars (absent, present); dorsal color pattern (trapezoidal "Bothrocophias microphthalmus-type" markings, rectangular "Bothrops ammodytoides-type" markings, C-shaped " $B$. alternatus-type" markings, trapezoidal " $B$. neuwiedi-type" markings, trapezoidal " $B$. jararaca-type" markings, trapezoidal " $B$. jararacussu-type" markings, banded "B. taeniatus-type" markings, trapezoidal " $B$. atrox-type" markings)*; green body coloration (absent, present); supraoculars (oval, rounded, elongated)*; middle preocular (not in contact with the orbit, contacting orbit); upper preocular (does not contribute, contributes to the canthus rostralis); lower preocular (not in contact, in contact with the orbit $)^{* * *}$; prelacunal (discrete, fused with second supralabial)*; prelacunal discrete (contacting third supralabial, contacting second supralabial, separated from second supralabial)*; subfoveals (incomplete row, complete row )*; loreal (not elongated, elongated); internasals (not elongated, elongated); rostral (triangular or subtriangular, quadrangular, trapezoidal); rostral (not elevated, elevated); canthus rostralis (not elevated, elevated forming a distinct ridge); intersupraoculars (smooth or slightly keeled, keeled); canthorostrals (absent, present); canthals (same size or slightly smaller than internasals, bigger than internasals and rounded, bigger than internasals and elongated)*; intercanthals (smooth or slightly keeled, keeled)***; upper preocular (entire, divided); tuberculate keels on mid-posterior dorsal scales (absent, present); middle preocular and supralacunal (fused, not fused); lowest preocular and sublacunal (not fused, partially or totally fused); intersupraocular fusions in plate-like scales (absent, usually present); subcaudals (entire, entire and divided, divided)*; body compressed laterally (absent, present)***; rattle (present, absent); hemipenis (U-shaped and lobes well separated, not U-shaped and lobes close to each other); lobes of the hemipenis (subcylindrical, cylindrical, fusiform)*; orientation of hemipenial lobes (parallel, divergent); distribution of hemipenial spines (heterogeneous, homogeneous)*; big sized spines in the hemipenis (absent, positioned distally, positioned proximally); hemipenial spines (straight or curved, hooked); intralobular spines (absent, distally in the intralobular area, along the intralobular area)*; microornamentation in the capitulum (in all calyces, in half or more of the calyces, in the basal calyces, absent); microornamentation in the ventral surface of the hemipenial body (in all the surface, in part of the surface); microornamentation in the dorsal surface of the hemipenial body (in part of the surface, in all the surface, absent)*; microornamentation in the intrasulcar area (absent, present); swollen dorsal area in hemipenial body (absent, present); swollen dorsal area in 
hemipenial body (well developed, poorly developed); lateral depression in hemipenial body (absent, present); lateral depression in hemipenial body (developed in both sides of the body, developed in one side of the body, poorly developed in one side of the body); swollen dorsal area in the intralobular area (absent, present) ${ }^{* * *}$.

Molecular sampling and phylogenetic approaches. To evaluate the systematic position of the new species within Bothrops we performed two different phylogenetic analyses, each with a different dataset. First, we analyzed a molecular dataset that included sequences of the new species, 43 species of Bothrops and nine outgroup taxa, based on three mitochondrial protein-coding genes (cytb: cytochrome $b$, nd4: NADH subunit 4, cox1: cytochrome $\mathrm{c}$ oxidase subunit I), two non-coding ribosomal genes (12S rRNA, 16S rRNA) and three tRNAs (histidine, serine, leucine) that flank the $n d 4$. Given that preliminary morphological comparisons indicated that the new species shares synapomorphic characters with the Bothrops neuwiedi species group (see taxonomic account below), we hypothesized that the new species was a member of this clade, and to test such hypothesis we included all mitochondrial sequences available in GenBank for this group of species. Additionally, we generated 35 DNA sequences for 13 species of Bothrops to prepare our molecular matrix together with 441 DNA sequences retrieved from GenBank (Appendix 2). In this way, the analysis was performed using one terminal for each of 34 species of Bothrops and multiple terminals for each of the eight species of the B. neuwiedi group.

Using multiple terminals for the species of the Bothrops neuwiedi group allowed us, not only to evaluate the position of the new species, but also to identify geographic and morphologically cohesive lineages, which might have implications in the taxonomy of the group as currently known (sensu Silva \& Rodrigues 2008). When possible, we revised the identification of the individuals used in molecular studies through the morphological evaluation of the voucher specimens (Appendix 2). Those molecular lineages that we found geographic and morphologically distinguishable were used as terminals in a subsequent phylogenetic analysis combining molecular and morphological data. The combined dataset included a morphological matrix conformed of continuous and discrete characters from the external morphology, hemipenial morphology and osteology. It was composed by the matrix used by Carrasco et al. (2012) with the addition of new data for some species and new characters (Appendix 3). Osteological characters were coded as missing data for the new species. The final combined dataset included 118 morphological characters (morphological matrix in Appendix 4) and the same 3143 aligned sites from the molecular matrix for 50 terminal taxa (which included the new species and all lineages for the $B$. neuwiedi group mentioned above) with a total of 923 parsimony-informative characters.

DNA sequencing and alignment. We extracted DNA from muscle following standard protocols (Hillis et al. 1996). Sequences were amplified via polymerase chain reaction (PCR) using the primers and protocols as described by Grazziotin et al. (2012) and Machado et al. (2014). PCRs for coding genes were performed with addition of BSA (bovine serum albumin) to increase the efficiency of amplification. The annealing temperature for $c y t b, n d 4$ and coxl ranged from $60^{\circ} \mathrm{C}$ to $58^{\circ} \mathrm{C}$ and $54^{\circ} \mathrm{C}$ for the rRNAs. The PCRs were purified with shrimp alkaline phosphatase and exonuclease I (GE Healthcare, Piscataway, $\mathrm{NJ}$ ) and the sequences were processed using BigDye Terminator cycle sequencing kit in an ABI 373A sequencer (Applied Biosystems, Foster City, CA) at Laboratório Especial de Toxinologia Aplicada (LETA), Instituto Butantan, São Paulo, Brazil. Both strands were checked and contigs were assembled using Geneious 11.1.5 (Kearse et al. 2012). Sequences were aligned using MAFFT 1.3.6 (Katho et al. 2005) as implemented in Geneious. We used default parameters for gap opening and extension and the alignments for protein-coding genes were visually checked to verify the correct reading frame.

Phylogenetic methods. The analysis of our molecular dataset was performed using the maximum likelihood (ML) approach. We used PartitionFinder 2 (Lanfear et al. 2016) to choose the combined sets of partitioning schemes and models of molecular evolution based on the Akaike Information Criterion with correction (AICc). We treated the two rRNA genes and the tRNAs as separate partitions and partitioned protein coding genes by codon positions. We used the greedy search option in PartitionFinder, allowing only the selection GTR models as implemented in RAxML 8.2.3 (Stamatakis 2014) without any correction for proportion of invariant sites, as recommended in the RAxML's manual. We used RAxML 8.2.3 to perform the ML analyses conducting a rapid bootstrap analysis (1000 replicates) and search for the best scoring ML tree in the same run (option - $\mathrm{f}$ a).

We performed a combined molecular and morphological analysis under maximum parsimony (MP) using TNT 1.5 (Goloboff \& Catalano 2016). Continuous morphological characters were analyzed without discretization, represented as ranges of two standard deviations around the mean (Goloboff et al. 2006) and standardized to the same range (0-2) to avoid scaling problems. Additionally, we performed separate analysis of the molecular and morphological partitions. The total evidence analysis was performed under the New Technology search option with 
default parameters. Partitioned analyses were performed under the Traditional search option, using random addition sequences of Wagner trees, followed by the TBR algorithm, making 500 replications and saving up to 10 trees per replicate. In both total evidence and partitioned analyses, all characters were analyzed under equal weights and implied weights (Goloboff 1993; Goloboff et al. 2008). For implied weighting we used values for the concavity constant $(\mathrm{k})$ between 8-15 in total evidence and molecular-only analysis and 3-10 in the morphologyonly analysis. To evaluate branch support we calculated group frequencies using jackknife and bootstrap methods, performing 500 pseudoreplicates ( 10 random addition sequences each) followed by TBR swapping, saving up to 10 trees, and using a probability of elimination of $\mathrm{P}=0.36$ for jackknife values.

\section{Results}

Analysis based on molecular evidence. Our final aligned dataset included 3143 base pairs (415 bp from 12S; 504 bp from 16S; $643 \mathrm{bp}$ from cox 1; $783 \mathrm{bp}$ from $c y t b ; 694 \mathrm{bp}$ from $n d 4$; and $104 \mathrm{bp}$ from the tRNAs adjacent to $n d 4$ ) and 204 terminal taxa. The ML analysis of mtDNA haplotypes (Fig. 1) recovered the new species within Bothrops and nested within the monophyletic $B$. neuwiedi group. Bothrops neuwiedi was recovered as paraphyletic, while $B$. mattogrossensis, B. pauloensis, B. marmoratus, and B. diporus were recovered as polyphyletic; the only species recovered as monophyletic was $B$. pubescens. Most, if not all, the paraphyly and polyphyly of species may be attributed to misidentification of samples (terminals in green and red in Fig. 1). The new species was recovered within a well-supported clade composed of individuals identified in GenBank as Bothrops pauloensis from northwestern Bolivia (Ñuflo de Chávez, department of Santa Cruz) and as B. mattogrossensis from Serra da Borda, western Brazil (Vila Bela da Santíssima Trindade, state of Mato Grosso) (Figs. 1, 2). The evaluation of the genetic distance between the new species and the close related individuals was difficult due to the lack of overlap among gene fragments sampled in our dataset. Between the specimen from Serra da Borda and the new species only a small fragment (270 bp) of the cytb is comparable, and we did not find any difference between these two sequences. On the other hand, when evaluating the $n d 4$ alignment the new species presents a p-distance of 0.0046 (three differences in $657 \mathrm{bp}$ ) from the individuals from Ñuflo de Chávez. Unfortunately, there is no sequence overlap for the individual from Serra da Borda and the individuals from Ñuflo de Chávez. Voucher specimens of the haplotypes from Nuflo de Chávez and Serra da Borda were not available for morphological revision in this study. Then, we provisionally assigned these DNA sequences to a terminal named as Bothrops cf. sp. nov. and for the MP analysis we used the sequence of one of the specimens from Nuflo de Chávez, and morphological characters from geographically close specimens (Beni Department, in northern Bolivia) that lacked DNA sequences.

From the tree topology obtained in the ML analysis, we were able to identify 15 geographically and morphologically distinguishable lineages within the Bothrops neuwiedi group (Fig. 1; see an estimated distribution in Fig. 2 and morphological characterization in Table 2). All lineages are well supported by bootstrap values. We assigned to Bothrops diporus, B. erythromelas, B. lutzi, B. mattogrossensis, B. marmoratus, B. neuwiedi, B. pauloensis and $B$. pubescens those lineages that included identified specimens from and/or near to the type locality of each species respectively. We named the rest of the lineages as follows: Bothrops aff. diporus B. aff. mattogrossensis 1, B. aff. mattogrossensis 2, B. aff. mattogrossensis 3, B. aff. neuwiedi, B. aff. pubescens, and B. cf. sp. nov. We also reassigned some terminals to their specific lineages based on the re-identification of the voucher specimens (terminals in green in Fig. 1) or based on the phylogenetic position and the morphological characters of geographically similar individuals (terminals in red in Figure 1). It was not possible to assess the identification of some terminals in the molecular matrix, since they probably had their voucher specimens destroyed by the fire at Butantan Institute in 2010 (terminals in gray in Fig. 1).

The general topology of the ML tree (Fig. 1) indicates four main highly supported clades, as follows: clade 1 ( $84 \%$ of bootstrap value), composed by B. lutzi and B. erythromelas; clade $2(100 \%)$, formed by B. neuwiedi, B. aff. neuwiedi and $B$. marmoratus; clade 3 (100\%), including individuals of $B$. mattogrossensis, $B$. aff. mattogrossensis $1, B$. aff. mattogrossensis 2 and $B$. aff. mattogrossensis 3; clade 4 (100\%), comprised by $B$. diporus, $B$. aff. diporus, B. pauloensis, $B$. pubescens, $B$. aff. pubescens, $B$. sp. nov and the individuals assigned to $B$. cf. sp. nov. Clade 1 is retrieved as the sister group of all the other clades, but with low bootstrap values $(<70 \%)$. Clade 2 is the sister group of a clade composed by Clade 3 and Clade 4, both relationships were supported by low values of bootstrap. 


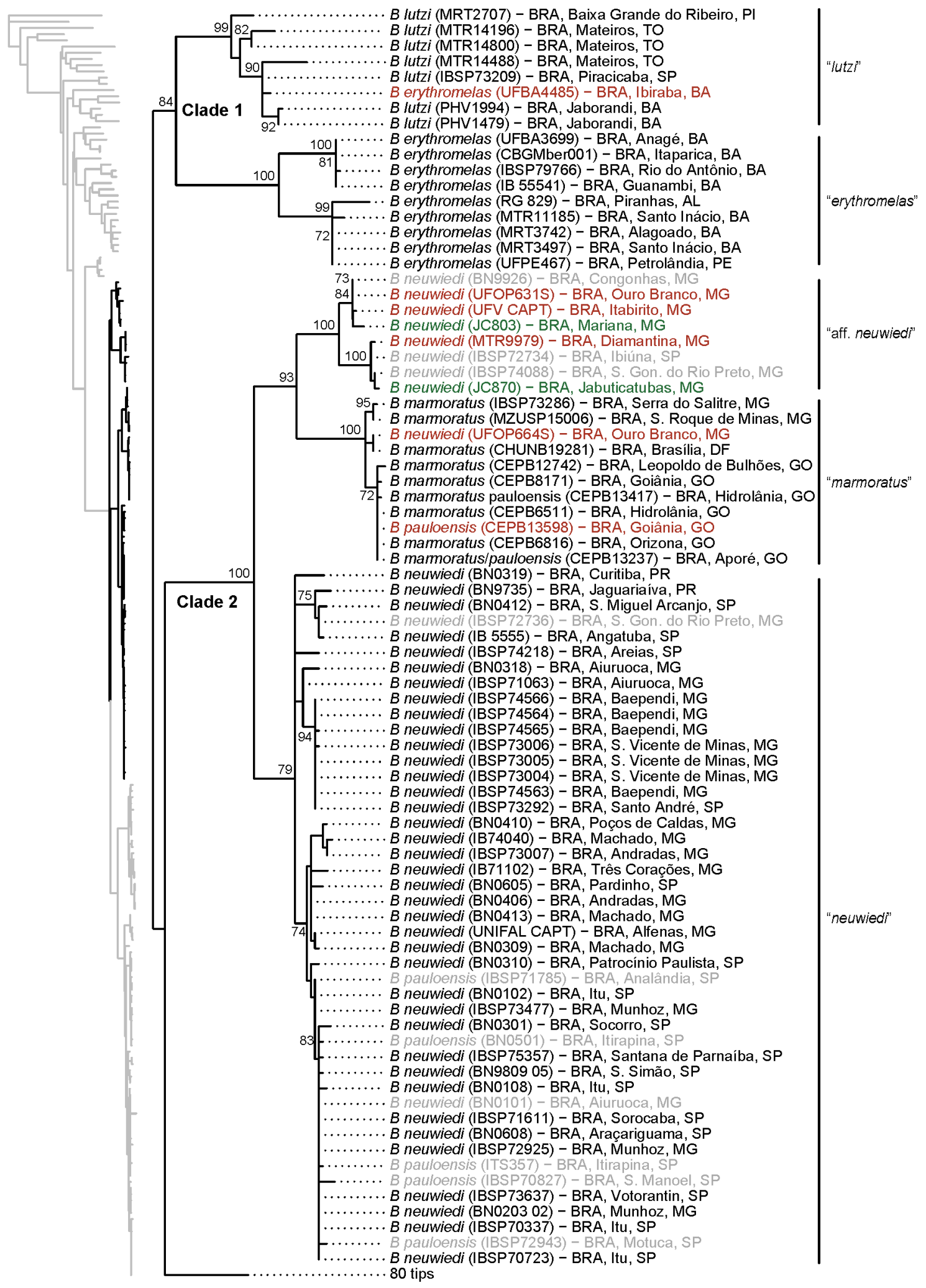




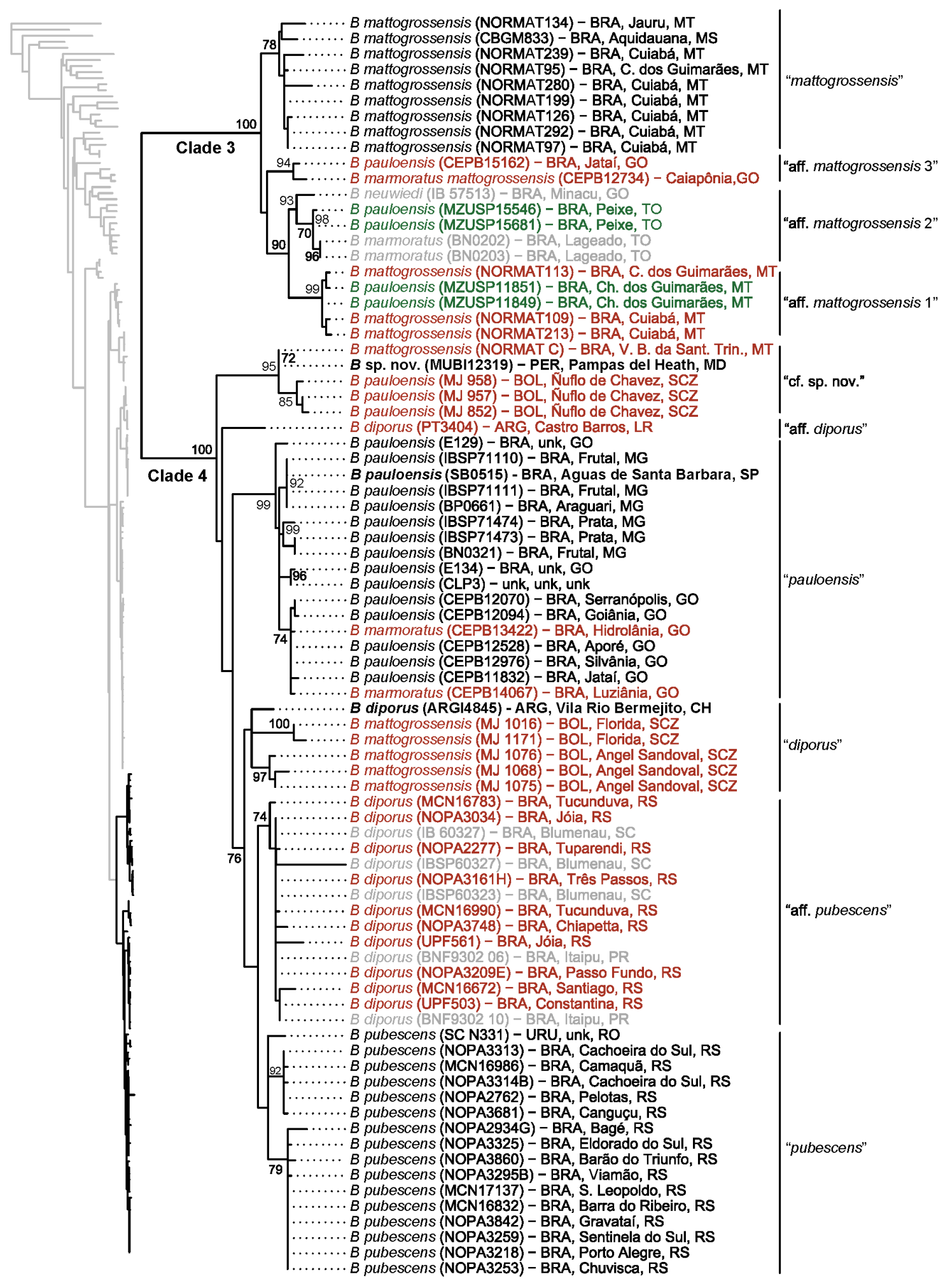

FIGURE 1. Maximum likelihood tree obtained in the analysis of mtDNA haplotypes, showing the relationships within the Bothrops neuwiedi species group. The topology of the complete ML tree is provided on the left. Numbers are bootstrap proportions. Color of terminal taxa: black=identification matches the assigned lineage, green=identification does not match the assigned lineage and voucher specimen was re-identified as belonging to the lineage after morphological examination, red= identification does not match the assigned lineage and voucher specimen could not be examined in this study, grey= identification does not match the assigned lineage and voucher specimens were lost during the fire at the Butantan collection in 2010. 


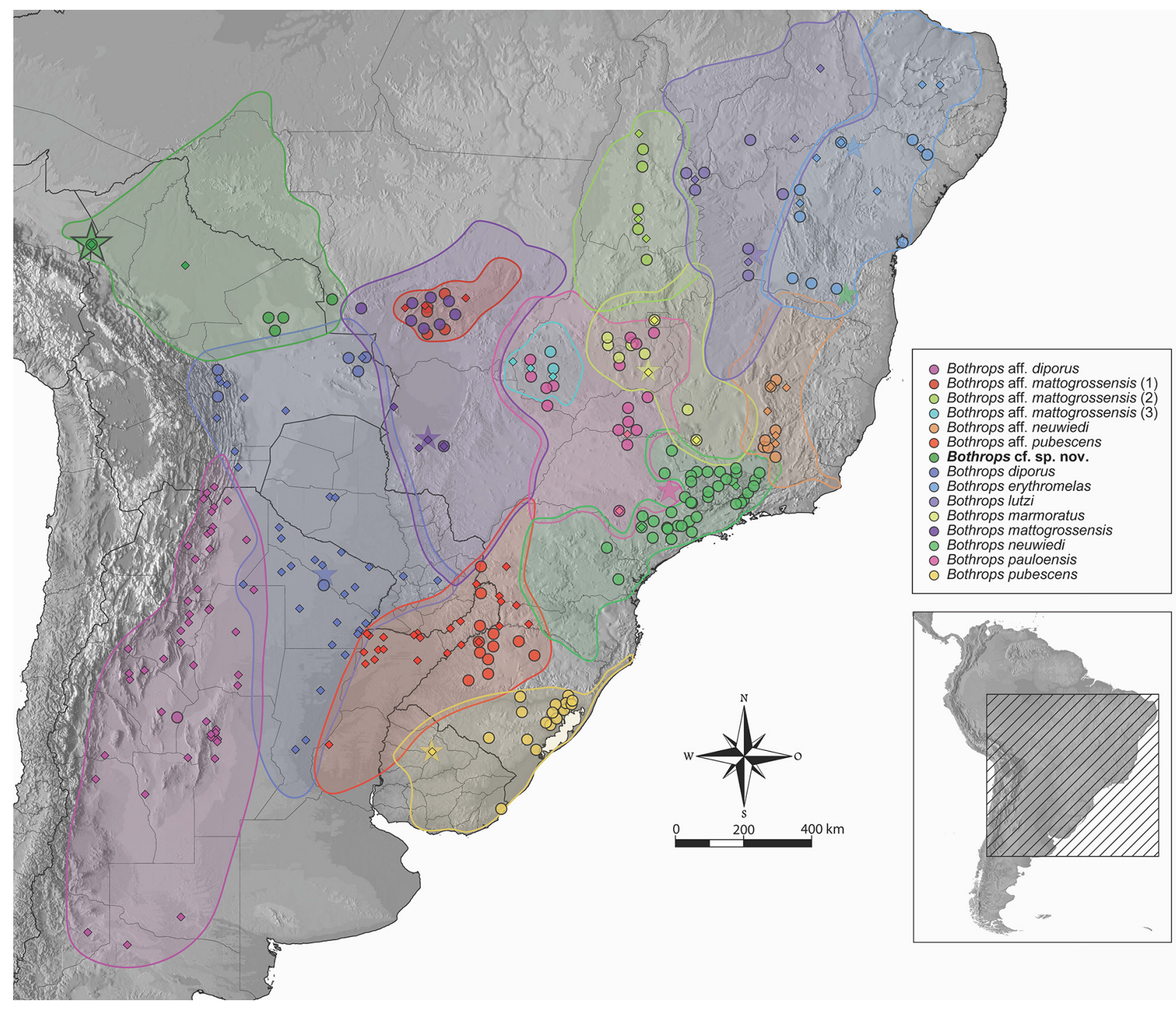

FIGURE 2. Distribution of the lineages of the Bothrops neuwiedi species group. Symbols are as follow: stars = type localities, circles $=$ records of specimens with DNA samples, squares $=$ records of specimens that were only examined morphologically.

Since the overlap among gene fragments is not complete in our dataset, we took the branch length/patristic distance (absolute time $\mathrm{x}$ mutation rate) among lineages as a proxy for the mitochondrial genetic distance. We estimated the mean branch length among the MRCAs (Most Recent Common Ancestor) for lineages within each main clade as follows: 0.0415 (4.1\%) for clade 1, 0.0341 (3.4\%) for clade 2, 0.0165 (1.7\%) for clade 3 and 0.0221 (2.2\%) for clade 4. Taking into account the average branch length of each terminal, the mean distance among lineages based on our ML tree are the following: 0.0473 (4.7\%) for clade 1, $0.0360(3.6 \%)$ for clade 2, 0.0199 (2.0\%) for clade 3 and $0.0246(2.5 \%)$ for clade 4 . The complete table showing the distances among lineages can be seen in Appendix 5. The MRCA of the lineage that includes the new species presents a minimum distance of $0.0199(2 \%)$ in relation to the MRCA of $B$. aff. diporus and a maximum distance of $0.1119(11 \%)$ in relation to $B$. marmoratus. Therefore, the patristic distance estimated among the new species and the other lineages falls into the average distance range among species/lineages of the B. neuwiedi group (Appendix 5).

MP total evidence analyses. The MP total evidence analysis recovered the same single tree under both EW and IW (Fig. 3). Similarly to the results of molecular ML analyses, the topology recovered Bothrops sp. nov. within the $B$. neuwiedi group and, together with $B$. cf. sp. nov., in a basal position to a clade conformed by $B$. diporus, B. pauloensis, B. pubescens and the related B. aff. diporus and B. aff. pubescens. The sister relationship between Bothrops sp. nov. and $B$. cf. sp. nov. was supported by two morphological synapomorphies (number of dorsolateral blotches and rounded or C-shaped dorsolateral blotches) and high jackknife and bootstrap values. The 
clade conformed by Bothrops sp. nov., B. cf. sp. nov., B. diporus, B. pauloensis, B. pubescens, B. aff. diporus and $B$. aff. pubescens was supported by three morphological synapomorphies (number of anterior intercanthals, subfoveals, and length of capitulum/length of hemipenial lobe) and high jackknife and bootstrap values. Differences between the results of ML molecular and MP total evidence analyses involved the position of Bothrops pauloensis and the relationships among $B$. mattogrossensis and B. aff. mattogrossensis 1-3. The topology obtained for the B. neuwiedi group in MP molecular-only analysis (Appendix 6) was the same than the one obtained in MP total evidence analyses. Morphology-only analyses, however, recovered different results (Appendix 7) in which (Bothrops sp. nov. + B. cf. sp. nov.) conformed a clade with B. lutzi, B. marmoratus, B. mattogrossensis, B. aff. mattogrossensis 1-3 and B. pauloensis. This relationship was supported by one morphological synapomorphy (venter heavily speckled) but unsupported by jackknife and bootstrap values.

Taxonomic decision. The new species was recovered in a distinct clade of geographically close specimens within the Bothrops neuwiedi species group. This result supported the hypothesized membership of the new species to that group, and confirmed the distinctiveness of this population from Pampas del Heath, which we describe below as a new species.

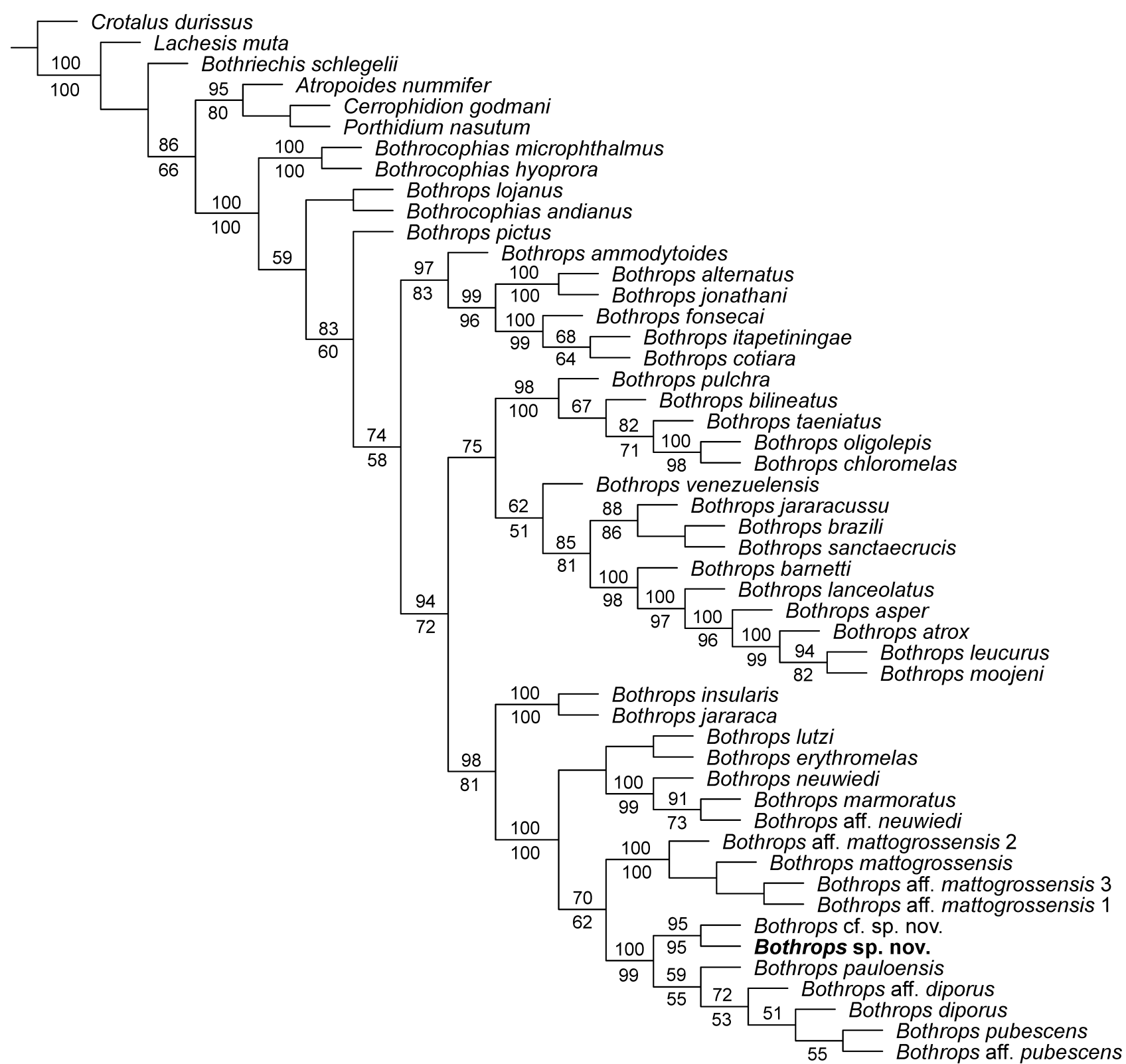

FIGURE 3. Maximum parsimony tree obtained in the analysis of total evidence under equal weights (single cladogram, length: 4153.215). Above and below nodes, jackknife and bootstrap proportions respectively. Values less than $50 \%$ are not shown. 
Bothrops sonene sp. nov.

Figures 4-7, Table 1

Bothrops gr. neuwiedi: Cadle et al. 2002: 102 (MUSM 33453, from Pampa Juliaca, department of Madre de Dios, Peru).

Holotype. An adult female, MUBI 12319, collected on April 23, 2013 by J.A. Ochoa at Pampa Juliaca (12 57’46.79” S, 68 55’22.61” W; 206 m above sea level, asl hereafter), Pampas del Heath (Bahuaja-Sonene National Park), district of Tambopata, province of Tambopata, department of Madre de Dios, Peru (Figs. 5A, 5E, 6B).

Paratypes. Three specimens, all from Pampa Juliaca, Pampas del Heath (Bahuaja-Sonene National Park), district of Tambopata, province of Tambopata, department of Madre de Dios, Peru. An adult male, MUBI 14679, collected on August 14, 2015 by J.A. Ochoa, G. Sebastián \& K. Huamani (12॰57’47.47” S, 6854’57.01” W; 210 m asl) (Figs. 5B, 5F, 6C). An immature male, MUSA 4350, collected on November 13, 2015 by R. Santa Cruz (12 57’2.47” S, 68 54'51.05” W; 209 m asl) (Figs. 4, 5C, 6A, D). An immature male, MUSM 33453, collected on between June $02-25,1996$ by J. Cadle (12 $59^{\circ} 20.10^{\prime \prime}$ S, 68 $55^{\circ} 48.45^{\prime \prime} \mathrm{W} ; 208 \mathrm{~m}$ asl) (Fig. 5D).

Diagnosis. Bothrops sonene can be distinguished from its congeners by the exclusive combination of the following morphological characters: dorsal color pattern of body consisting of small C-shaped blotches, apparently unique for the genus; postocular stripe originating posteriorly to the eye, two or two and a half scales width, covering three or four posterior supralabials; dorsum of the head with paired markings arranged symmetrically; venter cream heavily speckled with brown; lacunolabial scale absent, prelacunal discrete contacting second supralabial; prefoveals three to five; subfoveal single and usually present; postfoveals absent to two; canthals two; intersupraoculars seven; suboculars one or two; postoculars two or three; supralabials seven or eight; infralabials nine to eleven; interrictals 26-27; middorsal scales 23-25; ventrals 172 in the female, 169-173 in males; subcaudals divided, 45 in the female, 50 in males.

Comparisons. Bothrops sonene is easily distinguished from its congeners by its unique dorsal color pattern of relatively small and C-shaped blotches. It is distinguished from B. atrox, B. barnetti, B. jararaca, B. jararacussu, $B$. pictus and $B$. taeniatus by the absence of a lacunolabial scale (= prelacunal fused with second supralabial), a condition shared with the species of the B. alternatus and B. neuwiedi groups. Similar C-shaped (or in the shape of a headphone) dorsal blotches are present in B. alternatus, B. cotiara, B. fonsecai, B. itapetiningae and B. jonathani (B. alternatus group excluding $B$. ammodytoides, whose dorsal blotches are quadrangular); however, the blotches of $B$. sonene are smaller and rounder than those species, the lower set of blotches are well separated from each other (except in B. itapetiningae), and blotches are bordered with black (vs. bordered with white). The new species can also be distinguished from some species of the $B$. alternatus group by the postocular stripe starting posteriorly to the eye (vs. below the eye in B. alternatus, B. jonathani and B. ammodytoides), number of prefoveals (3-5 vs. 3$15)$, subfoveals ( $0-1$ vs. $1-6)$, supralabials ( 8 vs. $8-12$ ) and infralabials (9-11 vs. $10-15)$, length of hemipenes (relatively short vs. long), and fusiform and divergent hemipenial lobes (vs. parallel and subcylindrical lobes). Bothrops sonene is more similar to the B. neuwiedi group of species than to the rest of the species of the genus. They all have a symmetrical pattern of blotches in the dorsum of the head, a brown and relatively wide postocular stripe that extends posterior to the rictal region, a discrete prelacunal scale contacting the second supralabial, and similar number of prefoveals, subfoveals, supralabials and infralabials. They also bear resemblance in hemipenial morphology; the overall morphology of the hemipenis of the new species is identical to that of the species of the $B$. neuwiedi group, which is characteristic of that group. Differences in coloration and scalation between Bothrops sonene and the species of the B. neuwiedi group are summarized in Table 2.

Description of the holotype. Adult female; snout-vent length $950 \mathrm{~mm}$; tail length $123 \mathrm{~mm}$; caudal spine length $8.9 \mathrm{~mm}$; head length $44.8 \mathrm{~mm}$; maximum head width $36.5 \mathrm{~mm}$; interorbital space $7.2 \mathrm{~mm}$; internasal space $2.4 \mathrm{~mm}$; dorsal scale rows 23-24-19; ventral scales 172; subcaudal scales 45/45; rostral trapezoidal; canthus rostralis elevated forming a ridge; internasals $1 / 1$; canthals $1 / 1$, similar size than internasals; intercanthals, keeled, 4-5-5; intersupraoculars, keeled, 7; scales around supraoculars 11/10; supralabials 8/7; infralabials 10/11; postnasal in contact (left side) or not in contact (right side) with first supralabial; loreal subtriangular; prefoveals 5/ 5; subfoveal 1/0; postfoveals $1 / 1$; prelacunal contacting the second supralabial; sublacunals $1 / 1$; supralacunals $1 / 1$; suboculars $2 / 1$; postoculars $3 / 2$; upper preoculars contributing to the canthus rostralis, right preocular divided; upper and medial preoculars in contact with the orbit; inferior preoculars not in contact with the orbit; scales between suboculars and $3^{\text {rd }}-4^{\text {th }}$ supralabials $2 / 2$; scales between suboculars and $4^{\text {th }}$ supralabial $2 / 2$; scales between 
suboculars and $4^{\text {th }}-5^{\text {th }}$ supralabials $2 / 2$; interrictals 26 ; gulars 4 . Dorsal background color of body light brown; dorsum with dark brown, black-edged blotches, each blotch composed of dorsal and ventral C-shaped forms; ventral surface of body cream, heavily speckled with dark brown spots; dorsum of head with symmetrically arranged brown and dark-edged blotches, including a single blotch on the snout, a pair of blotches near supraoculars, a pair of parietal stripes that extend posterior-laterally, and a pair of occipital stripes that extend posteriorly; head with lateral, brown and black-bordered postocular stripes originating posterior to each eye.

TABLE 1. Morphometics (in $\mathrm{mm}$ ) and meristic variation of the types series of Bothrops sonene. Abreviations: $\mathrm{CaSp}=$ caudal spine, $\mathrm{G}=$ gulars, $\mathrm{ICa}=$ anterior intercanthals, $\mathrm{ICm}=$ medial intercanthals, $\mathrm{ICp}=$ posterior intercanthals, $\mathrm{IL}=$ infralabials, $\quad \mathrm{IOL}=$ interoculabials, $\quad \mathrm{IR}=$ interrictals, $\quad \mathrm{MD}=$ middorsals, $\quad \mathrm{PC}=$ postcanthals, $\mathrm{PF}=$ prefoveals, $\mathrm{PTF}=$ postfoveals, $\mathrm{PTO}=$ postoculars, $\mathrm{SBF}=$ subfoveals, $\mathrm{SBO}=$ suboculars, $\mathrm{ScSPO}=$ scales around supraoculars, $\mathrm{SL}=$ supralabials, $\mathrm{SVL}=$ snout-vent length, $\mathrm{TaL}=$ tail length, and $\mathrm{V}=$ ventrals.

\begin{tabular}{lllll}
\hline & Holotype & Paratype & Paratype & Paratype \\
& MUBI 12319 & MUBI 14679 & MUSA 4350 & MUSM 33453 \\
& Adult female & Adult male & Subadult male & Subadult male \\
\hline SVL & 950 & 470 & 373 & 290 \\
TaL & 123 & 83 & 61.9 & 49 \\
CaSp/TL & 0.07 & 0.04 & 0.07 & 0.07 \\
V & 172 & 173 & 169 & 170 \\
SC & 45 & 50 & 50 & 50 \\
MD & 24 & 25 & 23 & 24 \\
ScSPO & $11 / 10$ & $11 / 11$ & $10 / 10$ & $9 / 9$ \\
SL & $8 / 7$ & $8 / 8$ & $8 / 8$ & $8 / 7$ \\
IL & $11 / 10$ & $9 / 10$ & $10 / 10$ & $11 / 10$ \\
ICa & 4 & 5 & 5 & 4 \\
ICm & 5 & 6 & 6 & 4 \\
ICp & 5 & 7 & 7 & 5 \\
PF & $5 / 5$ & $4 / 4$ & $4 / 4$ & $3 / 4$ \\
SBF & $1 / 0$ & $1 / 1$ & $1 / 0$ & $1 / 0$ \\
PTF & $1 / 1$ & $2 / 1$ & $0 / 0$ & $0 / 0$ \\
SBO & $2 / 1$ & $1 / 1$ & $2 / 1$ & $1 / 1$ \\
PTO & $3 / 2$ & $2 / 2$ & $2 / 2$ & $2 / 2$ \\
IOL $3^{\text {rd }}-4^{\text {th }}$ SL & $2 / 2$ & $2 / 1$ & $1 / 1$ & $2 / 2$ \\
IOL $4^{\text {th }}$ SL & $2 / 2$ & $1 / 1$ & $2 / 1$ & $1 / 1$ \\
IOL $4^{\text {th }}-5^{\text {th }}$ SL & $2 / 2$ & $2 / 2$ & $2 / 2$ & $2 / 2$ \\
IR & 26 & 26 & 27 & 26 \\
G & 4 & 4 & 5 & 5 \\
\hline
\end{tabular}

Color pattern variation. Dorsal background color of head and body light brown with olive green tonality in live specimens; dorsum of body with 28-31 C-shaped, dark brown and black-edged, dorsal blotches; ventral portion of blotches formed by a pair of mostly-fused round blotches, forming a single curved blotch; ventral surface of body cream, speckled with dark brown spots, the spots forming a transversal stripe in some ventral scales; dorsum of head with brown, dark-edged, symmetrically arranged blotches; postocular stripes extend 1.5-3 scales posterior to rictal region, encroaching 3-4 supralabials and 1-2 infralabials; supralabials with dark brown spots, more conspicuous between $3^{\text {rd }}-5^{\text {th }}$ supralabials; infralabials mostly bordered with dark brown pigments. Gular region of males cream with irregular dark brown markings, absent in the female of the type-series suggesting a putative sexual dimorphism in this character; tip of tail pale ventrally in adult female and male (MUBI 14679); both dorsal and ventral surface of tip of tail pale in subadult males (MUSA 4350, MUSM 33453). 


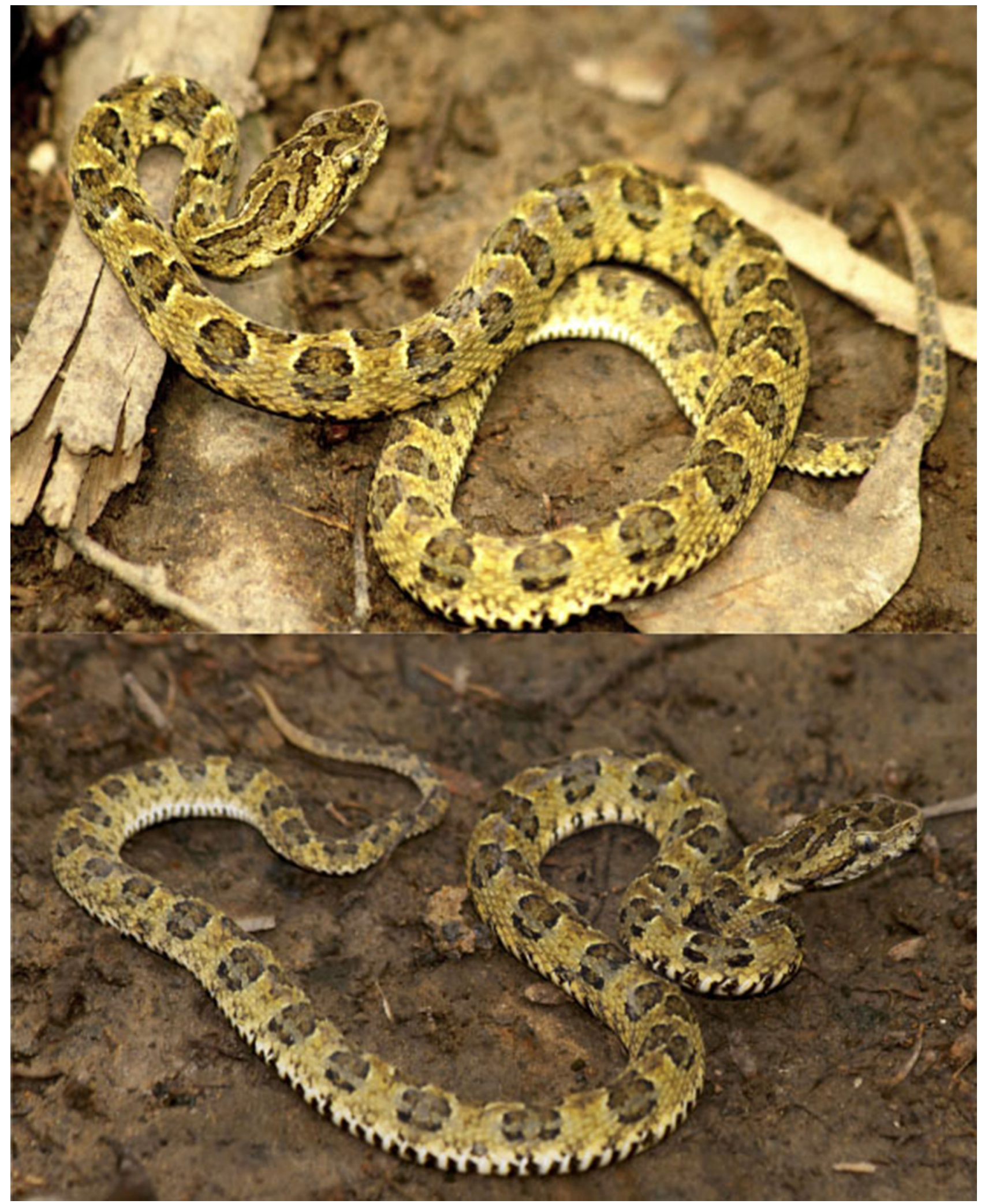

FIGURE 4. Bothrops sonene sp. nov. (MUSA 4350) from Pampas del Heath, Bahuaja-Sonene National Park, department of Madre de Dios, Peru. 

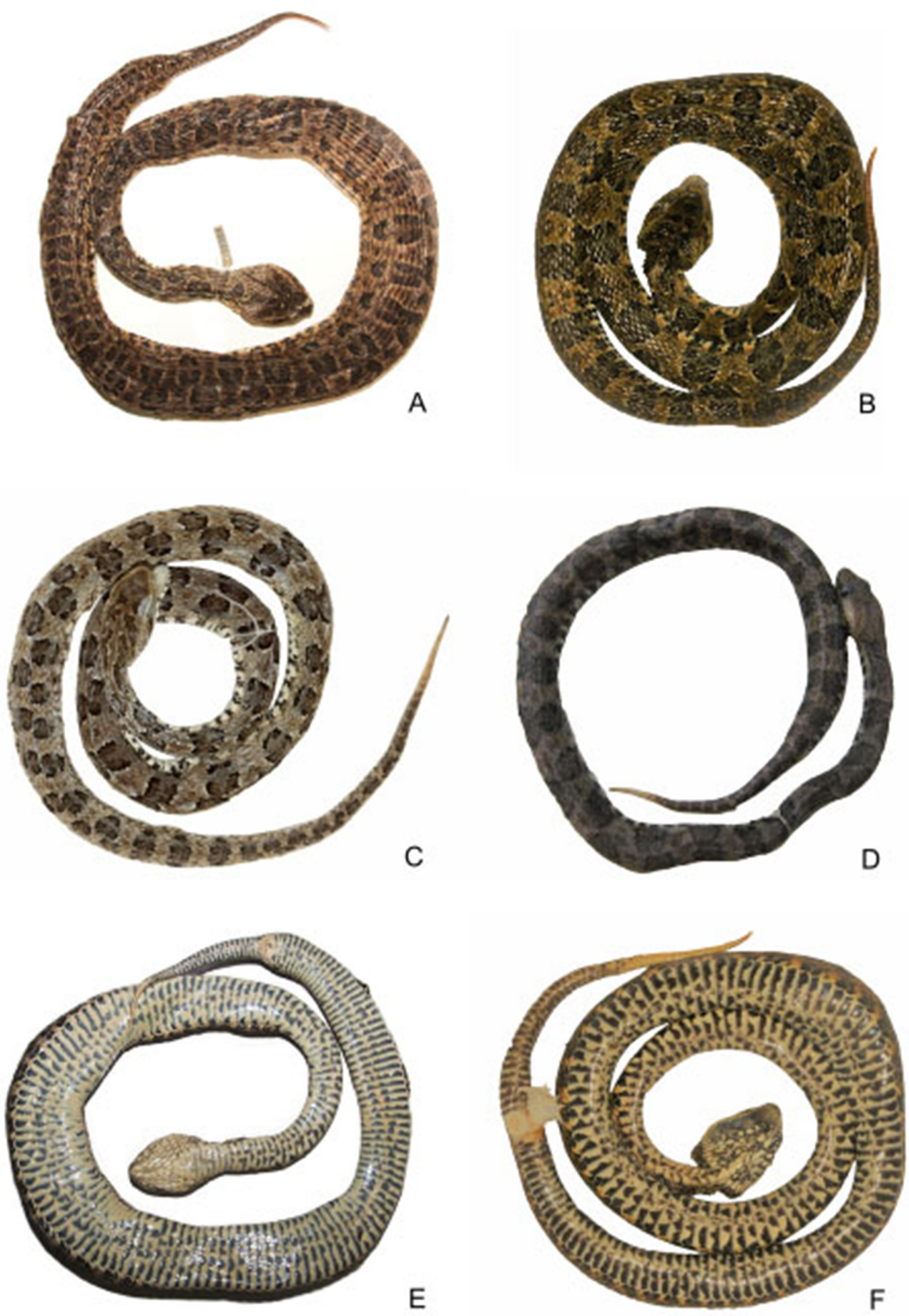

FIGURE 5. Dorsal view of the holotype (MUBI 12319—A, $1073 \mathrm{~mm}$ TL) and paratypes (MUBI 14679-B, 553 mm TL, MUSA 4350 - C, $435 \mathrm{~mm}$ TL, MUSM 33453-D, $339 \mathrm{~mm}$ TL) of Bothrops sonene. Ventral view of holotype (MUBI 12319E) and paratype (MUBI 14679-F). TL= total length. 

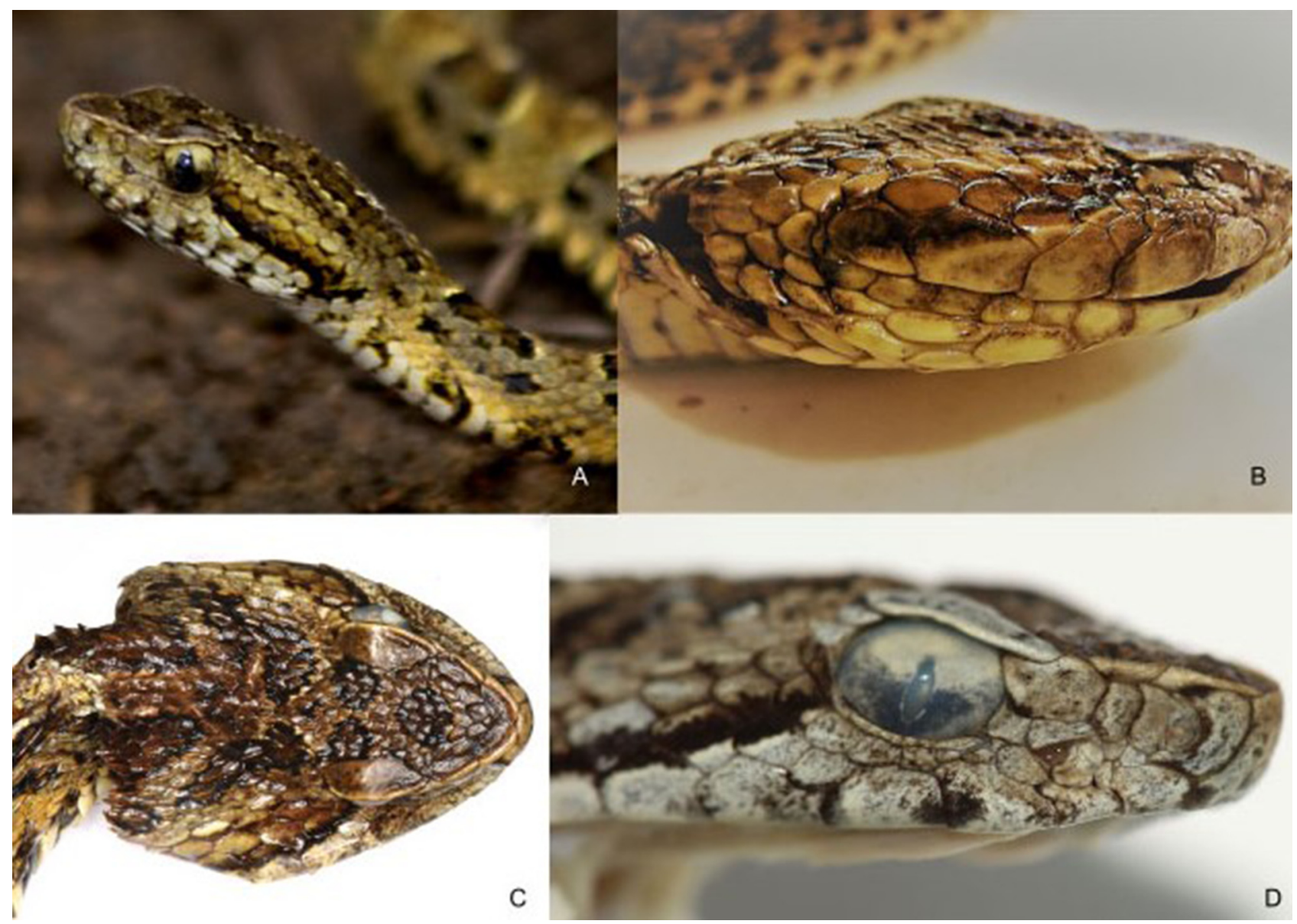

FIGURE 6. Dorsolateral view of head of the paratype (MUSA 4350—A, D, $20 \mathrm{~mm}$ HL) and holotype (MUBI 12319-B, 44.8 $\mathrm{mm} \mathrm{HL}$ ), and dorsal view of head (MUBI 14679—C, $23 \mathrm{~mm} \mathrm{HL}$ ) of the paratype of Bothrops sonene. HL= head length.

Hemipenis morphology. Based on MUBI 14679 and MUSA 4350. Organ strongly bilobed; hemipenial lobes fusiform and divergent, $67 \%$ of total hemipenial length; hemipenial body $33 \%$ of total hemipenial length; capitulum longer on sulcate side, occupying $62 \%$ of lobe; base of capitulum covered with spinulate calyces; hookshaped spines distributed asymmetrically on lobes, big sized spines located proximally; small, thin and curved spines present in the intralobular region, located distally on the lobes; hemipenial body covered with spinules; microornamentation on intrasulcar region absent; sulcus spermaticus bifurcating proximal to capitulum and ornamented with spinules (Fig. 7).

Distribution and natural history. Known to occur in Pampas del Heath, in the Bahuaja-Sonene National Park, province of Tambopata, department of Madre de Dios, Peru, at between 206-210 m asl (Fig. 2). The area is situated in southeastern Peru, near the border with Bolivia, between the Tambopata and Heath Rivers. Bothrops sonene is known from four close localities situated inside of the savannas of the Peruvian Pampas del Heath.

The specimens were collected at the end of the rainy season and during the dry season. They have diurnal activity; during the day they were observed on the ground and above grass at $500 \mathrm{~mm}$ above ground, sometimes slithering rapidly. They are associated with water bodies, which are widespread along the savannas of Pampas del Heath in rainy seasons (the soil is flooded up to $250 \mathrm{~mm}$ from the ground) and restricted to the "Aguajales" (Palm Tree areas) in dry seasons (Fig. 8).

Etymology. The specific epithet "sonene" is derived from the tacana language, and is the name used by the Ese'ejja for the Heath River. The Ese'ejja are an Amazonian community that inhabits the areas surrounding the Madre de Dios, Tambopata, and Heath Rivers, in the border between Peru and Bolivia. We named the new species "sonene" because its type locality, the Peruvian Pampas del Heath, is located near the Heath River. 


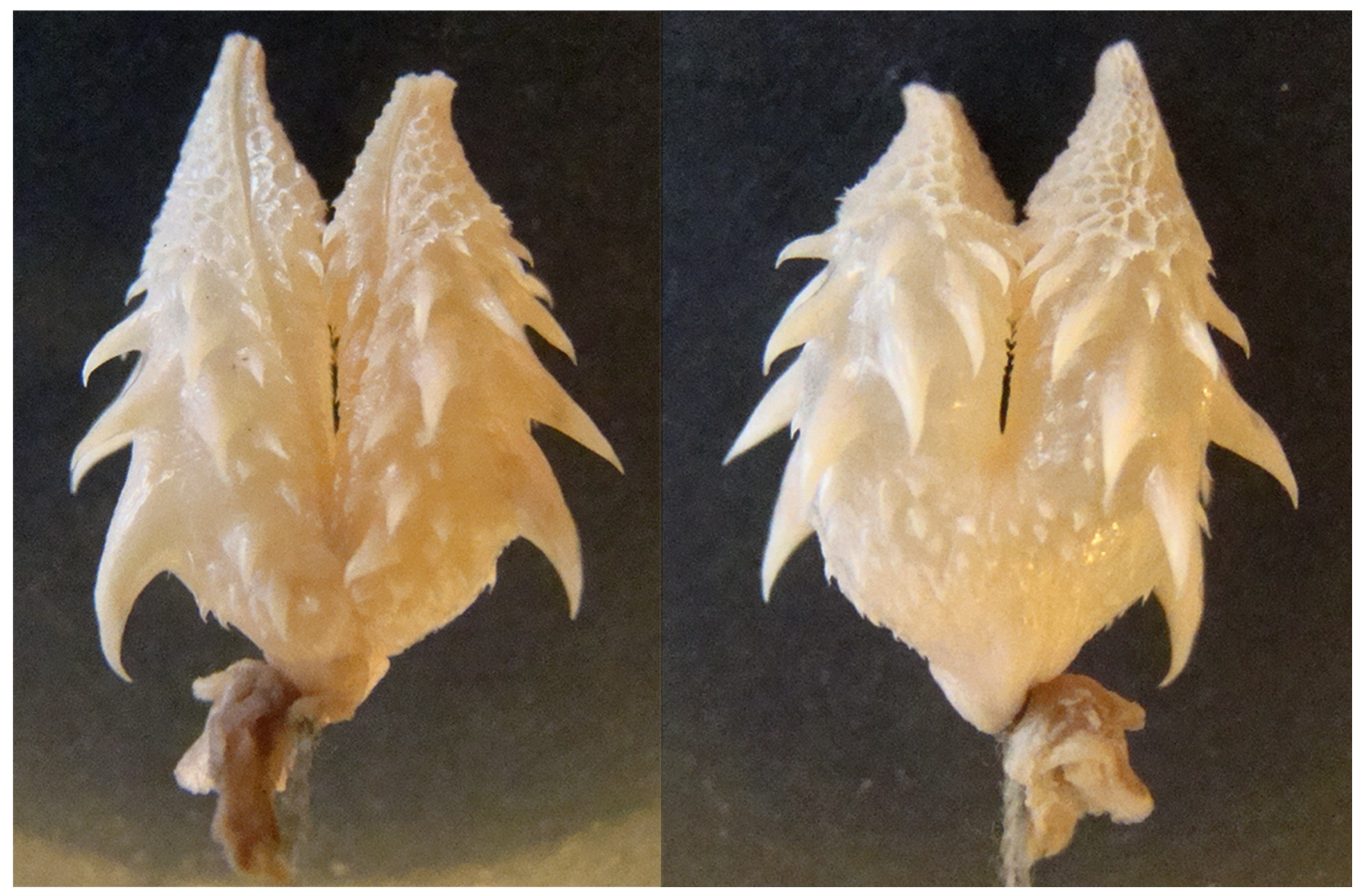

FIGURE 7. Sulcate (left) and asulcate (right) sides of the hemipenis of Bothrops sonene (MUBI 14670, 16.9 mm TL). TL = total length.

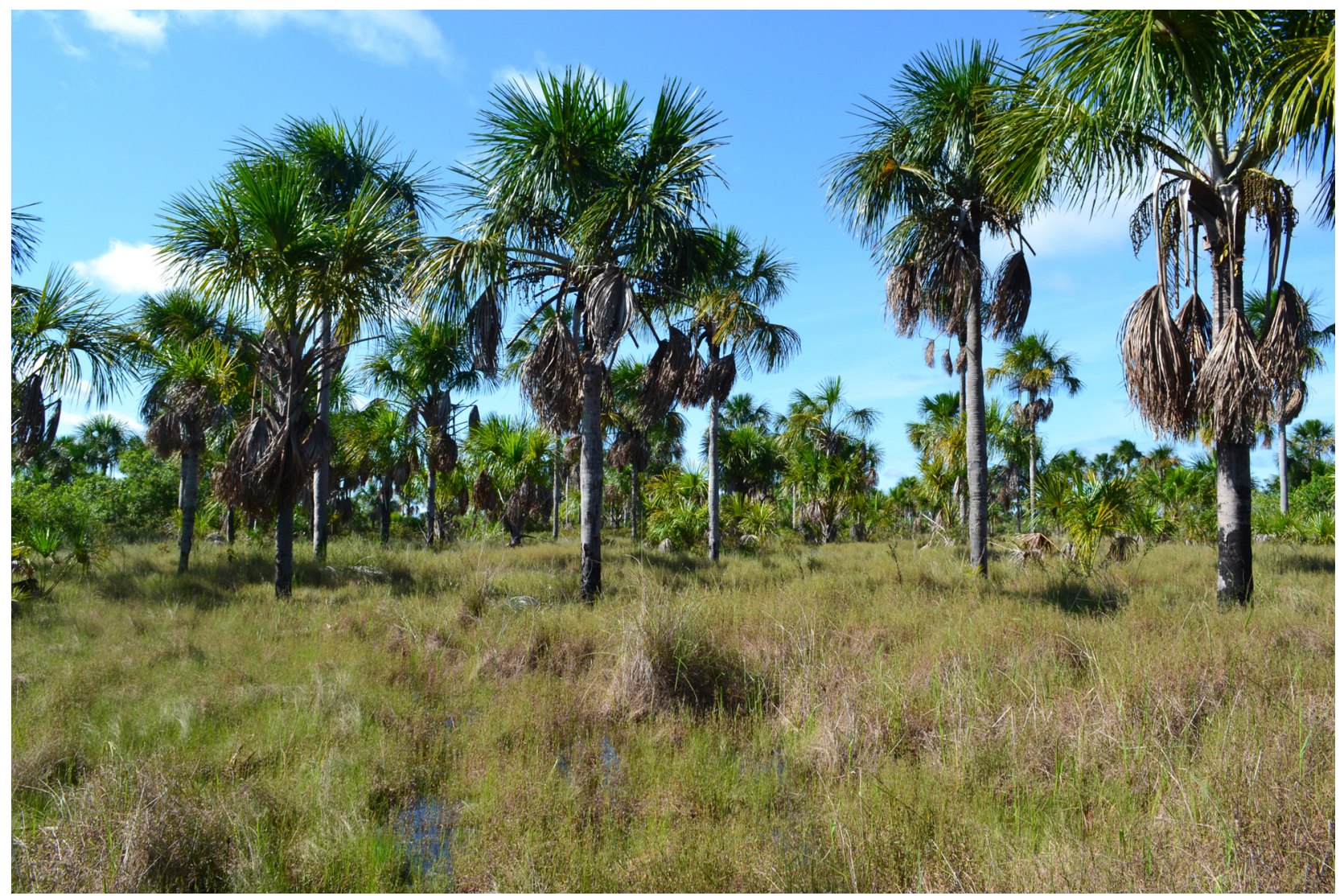

FIGURE 8. Landscape view of the type-locality of Bothrops sonene showing the "Aguajal" (Palm tree area) at Pampas del Heath (Bahuaja-Sonene National Park), department of Madre de Dios, Peru. 


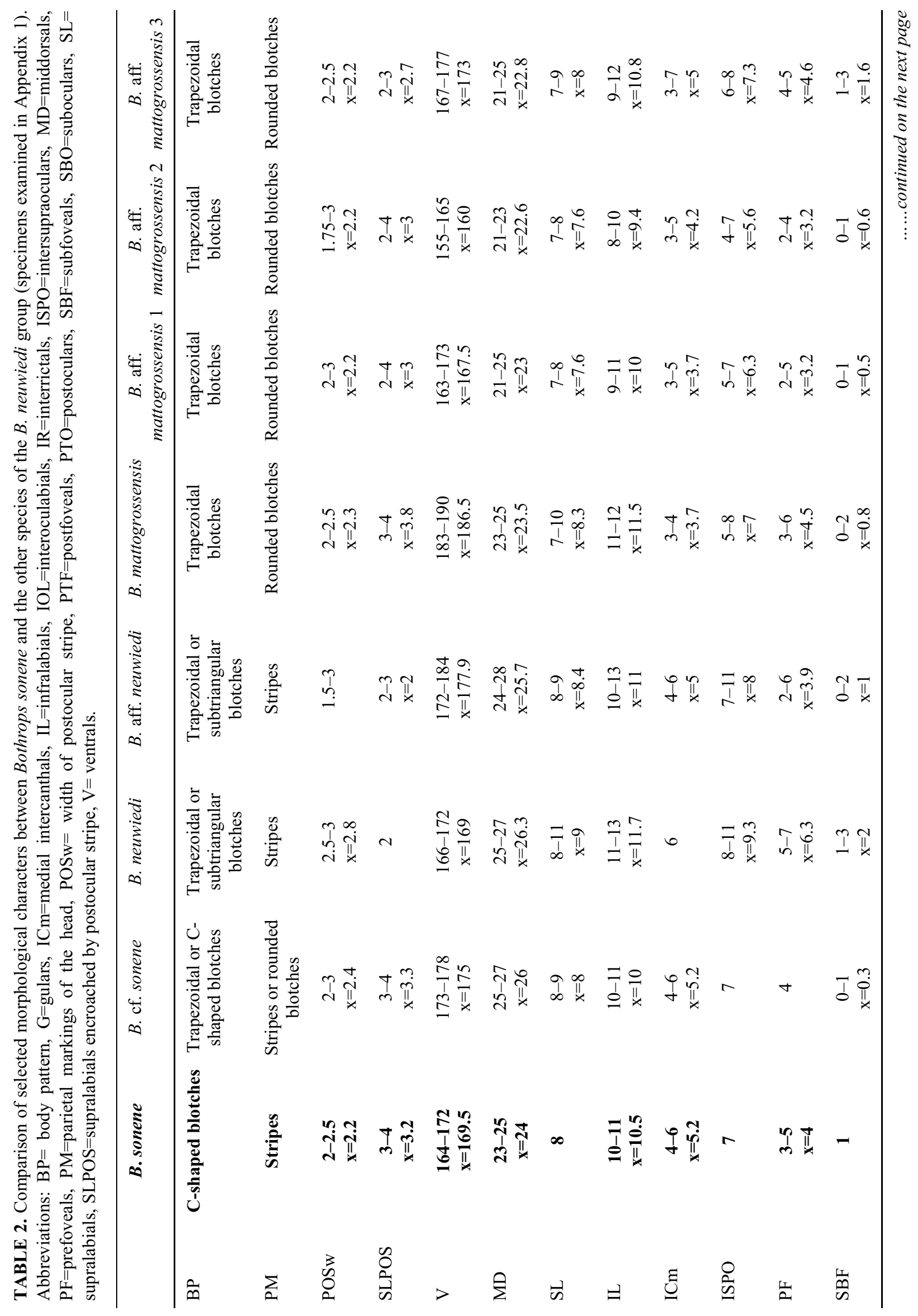



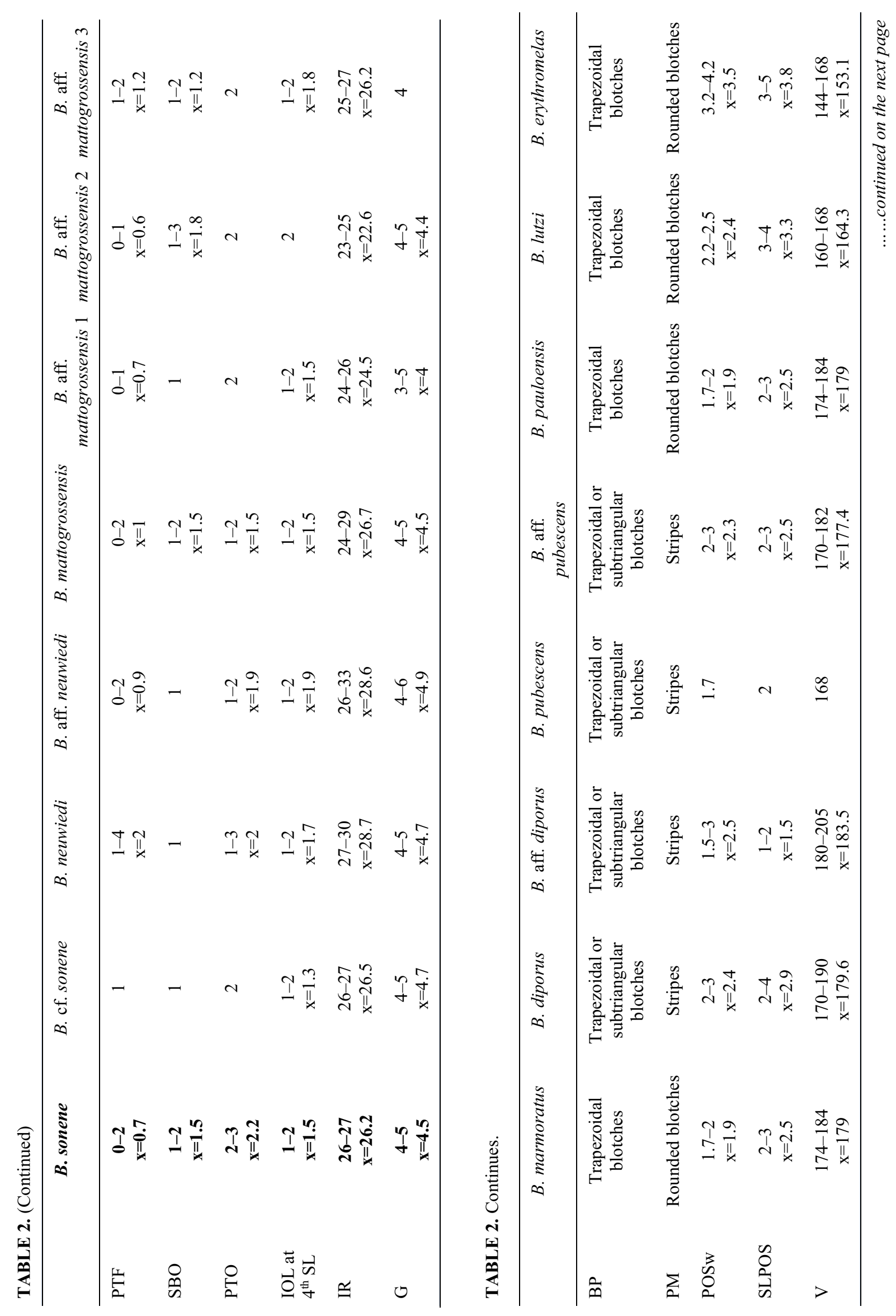


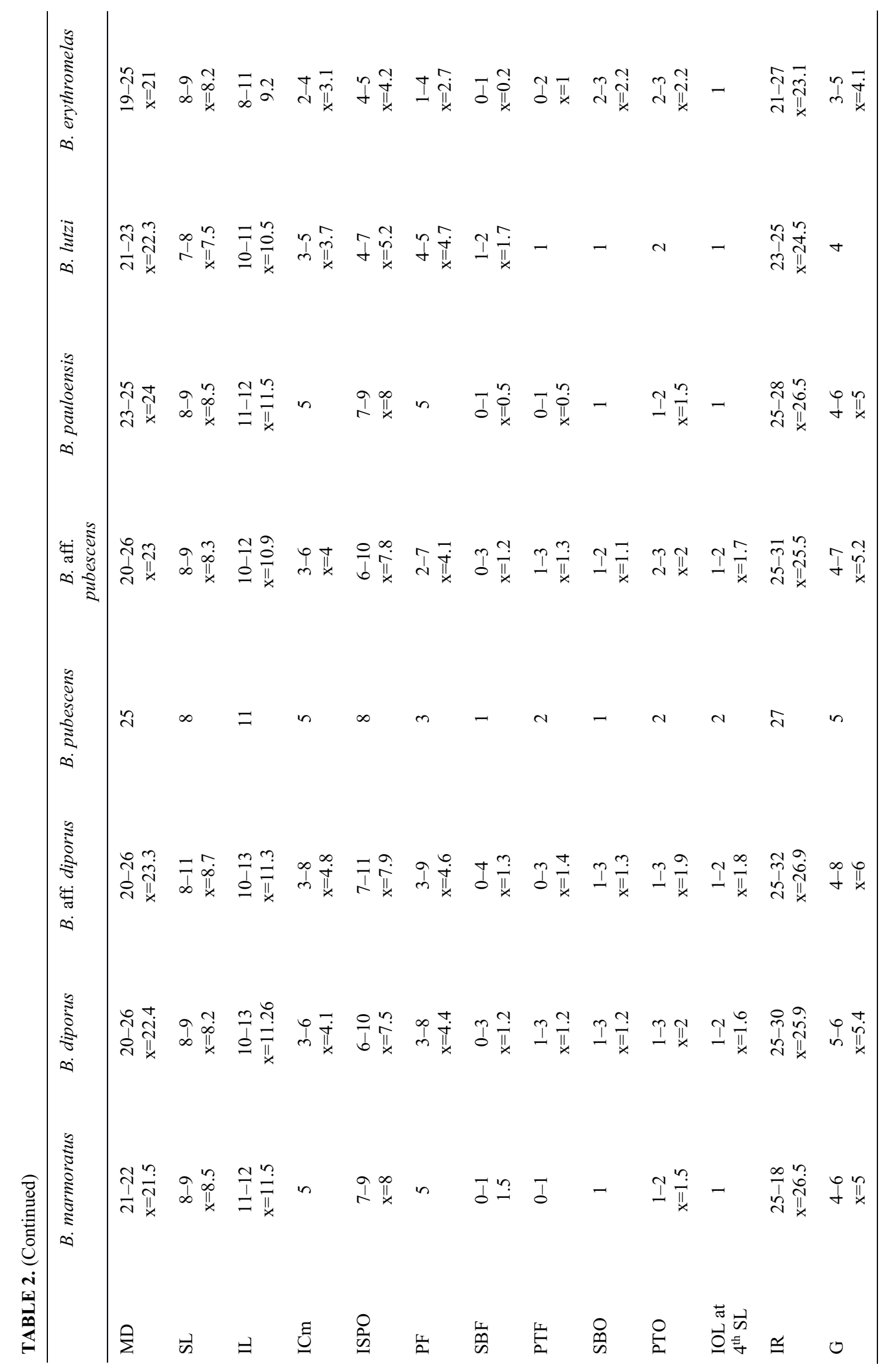




\section{Discussion}

Few species of Bothrops have been described in recent years, and most of them are from Brazil (Harvey 1994; Ferrarezi \& Freire 2001; Silva \& Rodrigues 2008; Barbo et al. 2012, 2016). The identification of Bothrops sonene in Pampas del Heath increases the number of known species of the genus, and also emphasizes the high diversity of South American open biomes (Myers et al. 2000; Colli et al. 2002; Nogueira et al. 2009; Werneck 2011; Werneck et al. 2011; Guedes et al. 2014, 2018). Another relevant aspect of the discovery of Bothrops sonene is that the species inhabits a protected area that is one of the most singular and lesser-known ecosystems in Peru. Pampas del Heath is the most northwestern incursion of the extensive grasslands at the east of the Heath River in Bolivia (Graham et al. 1980), and there is a high probability that Bothrops sonene, or a close relative, inhabit that area (see below). The Bolivian "pampas" are part of the ecoregion called the Beni savanna, which includes the La Paz Cerrado (in La Paz Department), the Llanos de Moxos (in Beni Department), and the Beni Cerrado (in Beni Department) (Olson et al. 2001; Larrea-Alcázar et al. 2010). Pampas del Heath and the Beni savannas may represent extensions of the Cerrado core (Werneck 2011; Werneck et al. 2012); however, they also share characteristics with Chaco, Chiquitania, and Pantanal. All of these ecoregions are inhabited by one or more species of the Bothrops neuwiedi group. Bothrops sonene is the westernmost representative of this group of species and may share some characteristics of its habitat with $B$. mattogrossensis, which is commonly found in the seasonally flooded areas of the Pantanal (Monteiro et al. 2006).

In the re-description of Bothrops mattogrossensis, Silva \& Rodrigues (2008) mentioned that its distribution reaches Peru. The presence of representatives of the Bothrops neuwiedi species group in Peru was also suggested in a study of venoms of eleven pitviper species from the country (Guerra-Duarte et al. 2015, but see also Carrasco et $a l$. 2016), which included a sample assigned to B. neuwiedi. Neither study provided precise localities, and voucher specimens were not available for examination in the course of the present study; but it seems likely that both studies have referred to Bothrops sonene. We examined three specimens from Beni Department, northern Bolivia, identified as Bothrops neuwiedi (ZMH 6678, from unknown locality) and B. mattogrossensis (CBF 1554, 233, Santa Ana de Yacuma, at approximately $395 \mathrm{~km}$ southeast from Pampas del Heath) that resemble the new species in dorsal coloration. Molecular data from these or other specimens from Beni Department were not available; the geographically closest DNA samples available corresponded to (following identification in GenBank) three specimens of Bothrops pauloensis from Ñuflo de Chávez (SC, Bolivia, MJ 952, 957, 958) and one of $B$. mattogrossensis from Serra da Borda (MT, Brazil, NORMAT Captivity), both localities at approximately 860 and $1010 \mathrm{~km}$ southeast from Pampas del Heath, respectively. As mentioned before, these haplotypes conformed a clade with the new species, but voucher specimens were not available for morphological examination. Interestingly, Machado et al. (2014), in their molecular study of the Bothrops neuwiedi group identified the B. mattogrossensis haplotype from Serra da Borda as a new candidate species. This evidence strongly suggests that Bothrops sonene may have a wider distribution than reported here; however, we chose to refer to these specimens from Beni, Santa Cruz and Mato Grosso as B. cf. sonene until additional morphological and molecular evidence confirms their assignation to the new species.

Our results are conclusive regarding the membership of Bothrops sonene to the monophyletic B. neuwiedi species group. Most of the analyses we performed recovered the new species in a basal position to a clade that included Bothrops diporus, B. pauloensis, B. pubescens, B. aff. diporus and B. aff. pubescens, thus belonging to the southwest clade identified by Machado et al. (2014). This position for Bothrops sonene was supported by both molecular and morphological characters and high branch support values. The different position recovered by morphological-only analyses was apparently given by some homoplasy and was unsupported by jackknife and bootstrap values.

Giraudo (2001) and Machado et al. (2014) highlighted on the necessity of a taxonomic revision of the Bothrops neuwiedi species group, and our results agree with their statement. Silva \& Rodrigues (2008) performed a comprehensive taxonomic review of the group, recognizing the long-standing 12 subspecies as seven species and adding the new Bothrops marmoratus. However, that taxonomy presented a set of diagnostic characters, mostly from coloration, which does not allow unquestionable identifications. The recent extensive molecular study presented by Machado et al. (2014), besides bringing light to the complexity of the genetic structure within the Bothrops neuwiedi group, also indicated the incongruences between the taxonomy proposed by Silva \& Rodrigues (2008) and the tree topology generated based on molecular evidence. Unfortunately, since much of the DNA 
samples with doubtful identifications in GenBank were not evaluated morphologically in this study, or had their voucher specimens lost or even originally had no clear voucher information, the taxonomic and geographical limits of the species recognized in the current taxonomic arrangement of the Bothrops neuwiedi group are unclear and requires to be consider as tentative.

Populations from Argentina, Bolivia and Paraguay, a wide area within the distribution range of the Bothrops neuwiedi group which mostly correspond to the Chacoan region, should be assigned to B. mattogrossensis and $B$. diporus according to Silva \& Rodrigues (2008). In this study we observed that specimens of Bothrops mattogrossensis from that region do not fit the morphotype described for that species, but resemble or are indistinguishable from specimens of $B$. diporus from the same region. We also observed that specimens of Bothrops diporus from Argentina showed significant differences in coloration with specimens of $B$. diporus from Brazil. Giraudo (2001) noted that populations from northeastern Argentina (province of Misiones and part of the province of Corrientes) differed in coloration from populations of the rest of the country, but were similar to populations from the states of Paraná and Rio Grande do Sul (Brazil). The lineages we identified in this study indicate that Bothrops mattogrossensis and B. diporus represent each of them a putative complex of species. Results showed that specimens from center of Bolivia relates phylogenetically with the specimen from near the area of the type locality of Bothrops diporus in northern Argentina ("region of Rio Vermejo [Bermejo], border between Paraguay and Argentina"). Results also indicated that specimens of Bothrops diporus from the west of Argentina (probably from northwest to south) conform a distinct clade ( $B$. aff. diporus), as was reflected in the position of the sample from Castro Barros (La Rioja Province) in our results and also those of Machado et al. (2014). Specimens of Bothrops diporus from Brazil conformed a distinct clade (B. aff. pubescens) related to $B$. pubescens. Although we did not include molecular samples from northeastern Argentina, our morphological comparisons (and the observations of Giraudo 2001) suggest that they may also be included in that clade. Based on the results of our combined analyses we also corroborate the suggestion of Machado et al. (2014) that the lineage Bothrops aff. diporus represent a candidate new species from western Argentina. We also conclude that the lineages Bothrops aff. pubescens and B. aff. mattogrossensis 1-3 represent candidate new species. Although Bothrops aff. neuwiedi is morphologically and phylogenetically distinct from the nominal species $B$. neuwiedi (as considered here) from southeastern/southern Brazil, we prefer to be conservative about the taxonomic status of both lineages since the type locality of $B$. neuwiedi is southern Bahia state and we did not have access to any individual from such populations (Fig. 2).

The complexity of the diversification patterns within the Bothrops neuwiedi group is evident. Machado et al. (2014) mentioned introgressive hybridization, retention of ancestral polymorphism and morphological parallelism as possible historical processes involved in their current diversity; the great overlap of morphological characters among the species may be the result of those processes, challenging the attainment of clear diagnoses for the members of this group. However, the identification and description of Bothrops sonene and the preliminary morphological revision of the B. neuwiedi group of species we performed here also indicates that greater attention should be delivered to morphology and geographic distribution. Hopefully these results will contribute to clarify the systematics and the historical biogeography of this group of pitvipers inhabiting open biomes.

\section{Acknowledgements}

We are grateful to David Aranibar and Fredy Quispe (Servicio Nacional de Áreas Naturales Protegidas por el Estado Peruano-SERNANP) and to Deyvis C. Huamán for permits to conduct research and to collect in the Bahuaja-Sonene National Park. The biological monitoring program at Pampas del Heath was supported and conducted by SERNANP, the Programa de Conservación Andes-Amazonia from Frankfurt Zoological SocietyPeru, and the Asociación para la lnvestigación y Desarrollo Integral (AIDER), with support of the Museo de Historia Natural de la Universidad de San Agustín de Arequipa. We are grateful to Roberto Gutiérrez for coordinating some of the expeditions to Pampas del Heath. We thank Renato Bejarano, Jefferson Bedregal, Vanessa Quequejana, Thalia Condori, Germán Sebastián, Keyly Huamaní, Alex Tito, Paul Santos, Alejandro Portillo, Yohnny Toque, Nelson Lipa, and SERNANP staff at Pampas del Heath for assisting us in the field. Collection permits were issued by SERNANP throught Resolución Jefatural $N^{\circ}$ 007-2011-SERNANP-PNBS and the specimens described under the Museo de Biodiversidad del Perú (MUBI) were recognized by the Resolución 
de Dirección General N 024-2017-SERFOR/DGGSPFFS. We thank Inácio L. M. Junqueira de Azevedo (LETA) and Nancy da Rós (LETA) for providing sequencing facilities and laboratory assistance. For allowing the revision of specimens of museum collections, we are grateful to Pablo Venegas (CORBIDI), Evaristo López Tejeda (MUSA), James Aparicio (CBF), Arturo Muñoz Saravia (MHNC), Lucindo González (MNK), Jakob Hallermann and Alexander Haas (ZMH), Silke Schweiger and Georg Gasner (NHM), Raffael Ernst and Markus Auer (MTKD), Andreas Schmitz (MHNG), Hussam Zaher (MZUSP), Sonia Kretzschmar and Esteban Lavilla (FML), Soledad Palomas (UNNE), Julián Faivovich (MACN) and Jorge Williams (MLP). We are grateful to Alejandro Giraudo for providing the tissue sample from Río Bermejito, and to Flora Roncolatto Ortiz for helping in morphological revisions. We thank Eugenia Lascano for helping with the figures edition and Helena Shobe for improvements to the English version of the manuscript. We are grateful to Allyson Fenwick, Paulo Passos and Wolfgang Wüster for constructive criticism and useful suggestions on early versions of the manuscript. We are indebted to the Willi Hennig Society for making TNT program freely available (accessible at www.lillo.org.ar/phylogeny/tnt/). FGG was supported by grants 2012/08661-3, 2016/13469-5 and 2016/50127-5 from São Paulo Research Foundation (FAPESP). This study was supported by the Programa de Cooperación Científico-Tecnológica entre el Consejo Nacional de Ciencia, Tecnología e Innovación Tecnológica de Perú (CONCYTEC-FONDECYT CS-031-2014) y el Ministerio de Ciencia, Tecnología e Innovación Productiva de Argentina (MINCYT PE/13/06), and by the Consejo Nacional de Investigaciones Científicas y Técnicas (CONICET-PIP 11220150100788), Argentina.

\section{References}

Araújo, D.P. (2015) Biogeografia Histórica das Jararacas do grupo Bothrops alternatus (Serpentes, Viperidae). MSc. Dissertation, Universidade Estadual Paulista Júlio de Mesquita Filho, Rio Claro, 54 pp.

Barbo, F.E., Grazziotin, F.G., Sazima, I., Martins, M. \& Sawaya, R. (2012) A new and threatened insular species of lancehead from Southeastern Brazil. Herpetologica, 68, 418-429. https://doi.org/10.1655/HERPETOLOGICA-D-12-00059.1

Barbo, F.E., Gasparini, J.L., Almeida, A.P., Zaher, H., Grazziotin, F., Gusmão, R.B., Ferrarini, J.M.G. \& Sawaya, R.J. (2016) Another new and threatened species of lancehead genus Bothrops (Serpentes, Viperidae) from Ilha dos Franceses, Southeastern Brazil. Zootaxa, 4097 (4), 511-529. https://doi.org/10.11646/zootaxa.4097.4.4

Barros, V.A., Rojas, C.A. \& Almeida-Santos, S.M. (2014) Is rainfall seasonality important for reproductive strategies in viviparous Neotropical pit vipers? A case study with Bothrops leucurus from the Brazilian Atlantic Forest. Herpetological Journal, 24 (2), 69-77.

Cadle, J., Icochea, J., Zúñiga, J.P., Portilla, A. \& Rivera, C. (2002) La Herpetofauna encontrada en el Refugio Juliaca y en el Puesto de Vigilancia Enahuipa del Santuario Nacional Pampas del Heath. In: Montambault, J.R. (Ed.), Informes de las Evaluaciones Biológicas de Pampas del Heath, Perú, Alto Madidi, Bolivia, y Pando, Bolivia. Conservation International, Washington, D.C., pp. 52-57.

Campbell, J.A. \& Lamar, W.W. (2004) The Venomous Reptiles of the Western Hemisphere. Cornell University Press, Ithaca, $1032 \mathrm{pp}$.

Carrasco, P.A., Mattoni, C.I., Leynaud, G.C. \& Scrocchi, G.J. (2012) Morphology, phylogeny and taxonomy of Southamerican bothropoid pitvipers (Serpentes: Viperidae). Zoologica Scripta, 41, 109-124. https://doi.org/10.1111/j.1463-6409.2011.00511.x

Carrasco, P.A., Venegas, P.J., Chaparro, J.C. \& Scrocchi, G.J. (2016) Nomenclatural instability in the venomous snakes of the Bothrops complex: implications in toxinology and public health. Toxicon, 119, 122-128. https://doi.org/10.1016/j.toxicon.2016.05.014

Colli, G.R., Bastos, R.P. \& Araújo, A.F.B. (2002) The character and dynamics of the Cerrado Herpetofauna. In: Oliveira, P.S. \& Marquis, R.J. (Eds.), The Cerrados of Brazil: Ecology and Natural History of a Neotropical Savanna. Columbia University Press, New York, pp. 223-241. https://doi.org/10.7312/oliv12042

Fenker, J., Tedeschi, L.G., Pyron, R.A. \& de C. Nogueira, C. (2014) Phylogenetic diversity, habitat loss and conservation in South American pitvipers (Crotalinae: Bothrops and Bothrocophias). Diversity and Distributions, 2014, 1-12. https://doi.org/10.1111/ddi.12217

Ferrarezzi, H. \& Freire, E.M.X. (2001) New species of Bothrops Wagler, 1824 from the Atlantic forest of northeastern Brazil (Serpentes, Viperidae, Crotalinae). Boletim do Museu Nacional, Nova Série, Zoologia, 440, 1-10.

Giraudo, A.R. (2001). Serpientes de la Selva Paranaense y del Chaco Húmedo. L.O.L.A., Buenos Aires, 285 pp.

Goloboff, P.A. (1993) Estimating character weights during tree search. Cladistics, 9, 83-91.

Goloboff, P.A., Mattoni, C.I. \& Quinteros, S. (2006) Continuous characters analyzed as such. Cladistics, 22, $589-601$. https://doi.org/10.1111/j.1096-0031.2006.00122.x 
Goloboff, P.A., Carpenter, J.M., Arias, J.S. \& Miranda Esquivel, D.R. (2008) Weighting against homoplasy improves phylogenetic analysis of morphological data sets. Cladistics, 24, 1-16. https://doi.org/10.1111/j.1096-0031.2008.00209.x

Goloboff, P.A. \& Catalano, S.A. (2016) TNT version 1.5, including a full implementation of phylogenetic morphometrics. Cladistics, 32 (3), 221-238. https://doi.org/10.1111/cla.12160

Graham, G.L., Graves, G.R., Schulenberg, T.S. \& O'Neill, J.P. (1980) Seventeen bird species new to Peru from the Pampas del Heath. The Auk, 97, 366-370. Available from: https://sora.unm.edu/sites/default/files/journals/auk/v097n02/p0366p0370.pdf (accessed 21 October 2018)

Grazziotin, F.G., Zaher, H., Murphy, R.W., Scrocchi, G.J., Benavides, M.A., Zhang, Y.P. \& Bonatto, S.L. (2012) Molecular phylogeny of the New World Dipsadidae (Serpentes: Colubroidea): a reappraisal. Cladistics, 28 (5), 437-459. https://doi.org/10.1111/j.1096-0031.2012.00393.x

Guedes, T.B., Sawaya, R.J. \& Nogueira, C.C. (2014) Biogeography, vicariance and conservation of snakes of the neglected and endangered Caatinga region, north-eastern Brazil. Journal of Biogeography, 41, 919-931. https://doi.org/10.1111/jbi.12272

Guedes, T.B., Sawaya, R.J., Zizka, A., Laffan, S., Faurby, S., Pyron, R.A., Bérnils, R.S., Jansen, M., Passos, P., Prudente, A.L.C., Cisneros-Heredia, D.F., Braz, H.B., de C. Nogueira, C. \& Antonelli, A. (2018) Patterns, biases and prospects in the distribution and diversity of Neotropical snakes. Global Ecology and Biogeography, 2018, 27, 14-21. https://doi.org/10.1111/geb.12679

Guerra-Duarte, C., Lopes-Peixoto, J., Fonseca-de-Souza, B.R., Stransky, S., Oliveira, D., Schneider, F.S., Lopes-de-Souza, L., Bonilla, C., Silva, W., Tintaya, B., Yarlequé, A. \& Chávez-Olórtegui, C. (2015) Partial in vitro analysis of toxic and antigenic activities of eleven Peruvian pitviper snake venoms. Toxicon, 108, 84-96. https://doi.org/10.1016/j.toxicon.2015.09.007

Hartmann, M.T., Marques, O.A. \& Almeida-Santos, S.M. (2004) Reproductive biology of the southern Brazilian pitviper Bothrops neuwiedi pubescens (Serpentes, Viperidae). Amphibia-Reptilia, 25 (1), 77-85. https://doi.org/10.1163/156853804322992850

Harvey, M.B. (1994) A new montane pitviper (Viperidae: Bothrops) from Cochabamba, Bolivia. Proceedings of the Biological Society of Washington, 107, 60-66. Available from http://biostor.org/reference/81222 (accessed 21 October 2018)

Hillis, D.M., Mable, B.K. \& Moritz, C. (1996). Applications of molecular systematics. In: Hillis, D.M., Moritz, C. \& Mable, B.K. (Eds.), Molecular Systematics, 2nd ed. Sinauer Associates, Sunderland, pp. 515-544.

Hoffmann, R.K., Ponce del Prado, C.F. \& Otte, K.C. (1976) Registro de dos nuevas especies de mamíferos para el Perú, Odocoileus dichotoraus (Illiger-1811) y Chrysocyon brachyurus (Illiger-1811), con notas sobre su hábitat. Revista Forestal del Perú, 6, 61-81.

Katho, K., Misawa, K., Kuma, K.I. \& Miyata, T. (2002) MAFFT: a novel method for rapid multiple sequence alignment based on fast Fourier transform. Nucleic Acids Research, 30, 3059-3066.

Kearse, M., Moir, R., Wilson, A., Stones-Havas, S., Cheung, M., Sturrock, S., Buxton, S., Cooper, A., Markowitz, S., Duran, C., Thierer, T., Ashton, B., Meintjes, P. \& Drummond, A. (2012) Geneious basic: an integrated and extendable desktop software platform for the organization and analysis of sequence data. Bioinformatics, 28, 1647-1649. https://doi.org/10.1093/bioinformatics/bts 199

Lanfear, R., Frandsen, P.B., Wright, A.M., Senfeld, T. \& Calcott, B. (2016) PartitionFinder 2: new methods for selecting partitioned models of evolution for molecular and morphological phylogenetic analyses. Molecular Biology and Evolution, 34 (3), 772-773.

https://doi.org/10.1093/molbev/msw260

Larrea-Alcázar, D.M., López, R.P., Quintanilla, M. \& Vargas, A. (2010) Gap analysis of two savanna-type ecoregions: a twoscale floristic approach applied to the Llanos de Moxos and Beni Cerrado, Bolivia. Biodiversity and Conservation, 19, 1769-1783. https://doi.org/10.1007/s10531-010-9802-4

Luna, L., Emmons, L., Romo, M. \& Cornejo Farfán, A. (2002) Mamíferos encontrados en el Santuario Nacional Pampas del Heath durante la expedición del RAP de 1996. In: Montambault, J.R. (Ed.), Informes de las evaluaciones biológicas de Pampas del Heath, Perú, Alto Madidi, Bolivia, y Pando, Bolivia. Conservation International, Washington, D.C., pp. 6670.

Machado, T., Silva, V.X. \& Silva, M.J.J. (2014) Phylogenetic relationships within Bothrops neuwiedi group (Serpentes, Squamata): geographically highly-structured lineages, evidence of introgressive hybridization and Neogene/Quaternary diversification. Molecular Phylogenetics and Evolution, 71, 1-14. https://doi.org/10.1016/j.ympev.2013.10.003

Monteiro, C., Montgomery, C.E., Spina, F., Sawaya, R.J. \& Martins, M. (2006) Feeding, reproduction, and morphology of Bothrops mattogrossensis (Serpentes, Viperidae, Crotalinae) in the Brazilian Pantanal. Journal of Herpetology, 40 (3), 408-413. https://doi.org/10.1670/0022-1511(2006)40[408:FRAMOB]2.0.CO;2

Myers, N., Mittermeier, R.A., Mittermeier, C.G., da Fonseca, G.A.B. \& Kent, J. (2000) Biodiversity hotspots for conservation priorities. Nature, 403, 853-858. 
https://doi.org/10.1038/35002501

Nogueira, C., Colli, G.R. \& Martins, M. (2009) Local richness and distribution of the lizard fauna in natural habitat mosaics of the Brazilian Cerrado. Austral Ecology, 34, 83-96.

https://doi.org/10.1111/j.1442-9993.2008.01887.x

Nogueira, C., Colli, G.R., Costa, G.C. \& Machado, R.B. (2010) Diversidade de répteis Squamata e evolução do conhecimento faunístico no Cerrado. In: Diniz, I.R., Marinho-Filho, J., Machado, R.B. \& Cavalcanti, R.B. (Eds.), Cerrado: Conhecimento Científico Quantitativo como Subsídio para Ações de Conservação. UnB, Brasília, pp. 333-375.

Oliveira-Filho, A.T. \& Ratter, J.A. (2002) Vegetation physiognomies and woody flora of the cerrado biome. In: Oliveira, P.S. \& Marquis, R.J. (Eds.), The Cerrados of Brazil: Ecology and Natural History of a Neotropical Savanna. Columbia University Press, New York, pp. 91-120. https://doi.org/10.7312/oliv12042-005

Olson, D.M., Dinerstein, E., Wikramanayake, E.D., Burgess, N.D., Powell, G.V.N., Underwood, E.C., D’Amico, J.A., Itoua, I., Strand, H.E., Morrison, J.C., Loucks, C.J., Allnutt, T.F., Ricketts, T.H., Kura, Y., Lamoreux, J.F., Wettengel, W.W., Hedao, P. \& Kassem, K.R. (2001) Terrestrial ecoregions of the world: a new map of life on earth. BioScience, 51 (11), $933-938$. https://doi.org/10.1641/0006-3568(2001)051[0933:TEOTWA]2.0.CO;2

Pennington, R.T., Lewis, G. \& Ratter, J. (2006) An overview of the plant diversity, biogeography and conservation of neotropical savannas and seasonally dry forests. In: Pennington, R.T., Lewis, G. \& Ratter J. (Eds.), Neotropical Savannas and the Seasonally Dry Forests. Taylor and Francis Group, Boca Raton, 1-29 pp.

Pesantes, O.S. (1989) Relacões entre Algumas Espécies do Gênero Bothrops pela Eletroforese do Plasma e Morfología do Hemipenis (Serpentes: Viperidae). MSc. Dissertation, Universidade Estadual Paulista Júlio de Mesquita Filho, Rio Claro, $85 \mathrm{pp}$. https://doi.org/10.1201/9781420004496.ch1

Pesantes, O.S. (1994) A method for preparing the hemipenis of preserved snakes. Journal of Herpetolology, 28, 93-95. https://doi.org/10.2307/1564686

Prado, D.E. \& Gibbs, P.E. (1993) Patterns of species distributions in the dry seasonal forests of South America. Annals of the Missouri Botanical Garden, 80, 902-927. https://doi.org/10.2307/2399937

Sabaj M.H. (2016) Standard symbolic codes for institutional resource collections in herpetology and ichthyology: an Online Reference. Available from: http://www.asih.org/, American Society of Ichthyologists and Herpetologists, Washington, DC. (accessed 21 October 2018)

Silva, V.X. (2004) The Bothrops neuwiedi complex. In: Campbell, J.A. \& Lamar, W.W. (Eds.), The Venomous Reptiles of the Western Hemisphere. Cornell University Press, Ithaca, pp. 410-422.

Silva, V.X. \& Rodrigues, M.T. (2008) Taxonomic revision of the Bothrops neuwiedi complex (Serpentes, Viperidae) with description of a new species. Phyllomedusa, 7, 45-90. https://doi.org/10.11606/issn.2316-9079.v7i1p45-90

Stamatakis, A. (2014) RAxML version 8: a tool for phylogenetic analysis and post-analysis of large phylogenies. Bioinformatics, 30 (9), 1312-1313. https://doi.org/10.1093/bioinformatics/btu033

Stotz, D.S., Montambault, J.R., Pequeño, T., Valdes, A., Mack, A. \& Quiroga, C. (2002) Evaluación de la avifauna de Pampas del Heath, Perú y Alto Madidi, Bolivia. In: Montambault, J.R. (Ed.), Informes de las Evaluaciones Biológicas de Pampas del Heath, Perú, Alto Madidi, Bolivia, y Pando, Bolivia. Conservation International, Washington, D.C., pp. 45-51.

Uetz, P. \& Hošek, J. (2017) The Reptile Database. Available from: http://www.reptile-database.org (accessed 21 October 2018)

Vanzolini, P.E. (1963) Problemas faunísticos do Cerrado. In: Ferri, M.G. (Ed.), Simpósio Sôbre o Cerrado. University of São Paulo Press, São Paulo, pp. 307-320.

Werneck, F.P. (2011) The diversification of eastern South American open vegetation biomes: Historical biogeography and perspectives. Quaternary Science Reviews, 30, 1630-1648. https://doi.org/10.1016/j.quascirev.2011.03.009

Werneck, F.P., Costa, G.C., Colli, G.R., Prado, D. \& Sites Jr., J.W. (2011) Revisiting the historical distribution of seasonally dry tropical forests: new insights based on palaeodistribution modelling and palynological evidence. Global Ecology and Biogeography, 20, 272-288.

https://doi.org/10.1111/j.1466-8238.2010.00596.x

Werneck, F.P., Nogueira, C., Colli, G.R., Sites, J.W. \& Costa, G.C. (2012) Climatic stability in the Brazilian Cerrado: implications for biogeographical connections of South American savannas, species richness and conservation in a biodiversity hotspot. Journal of Biogeography, 39 (9), 1695-1706. https://doi.org/10.1111/j.1365-2699.2012.02715.x

Williams, R.S., Torres, E., Magan, J., Cruz, A. \& Leite-Pitman, R. (2012) Confirmation of the continued presence of the maned wolf in Peru. Canid news. Available from: http://www.canids.org/canidnews/15/Maned_wolf_in_Peru.pdf (accessed 29 December 2017)

Zaher, H. (1999) Hemipenial morphology of the South American Xenodontinae, with a proposal for a monophyletic Xenodontinae and a reappraisal of Colubroid hemipenes. Bulletin of the American Museum of Natural History, 240, 1168. Available from: http://hdl.handle.net/2246/1646 (accessed 21 October 2018) 


\section{Supplementary Material}

\section{APPENDIX 1. Specimens examined.}

Atropoides nummifer - HONDURAS. Tela: MZUSP 2030. San Pedro Sula: MZUSP 8231.

Bothriechis schlegelii-PANAMA. Isthmus of Panamá: MZUSP 2072. Unknown locality: FML 99.

Bothrocophias andianus-BOLIVIA. COCHABAMBA. Chapare: MNK 3722. SANTA CRUZ. Florida: MNK 2715, 2955, 3327, 4319, 4542, 4543. LA PAZ. El Piñalito: CBF 221; Irupana: CBF 467. PERU. CUSCO. Machu Picchu: MUSM 2324, 2680, 3093, MUBI 5100; Quimbiri: MUSM 26492; Alto Shimá Native Community: CORBIDI 8355; Urusayhua: MUBI 13641, 13654; Monte Carmelo: MUBI 10501-02. Capire: CORBIDI 14690; Manu Cloud Forest Lodge: MUBI 5060; Alto Pilcomayo: MUBI 13376.

Bothrocophias hyoprora-BRAZIL. AMAZONAS. Praínha: MZUSP 5193. MATO GROSSO. Aripuanã: MZUSP 11152. COLOMBIA. META. La Macarena: MZUSP 6109. ECUADOR. NAPO. Cuyabeno: MZUSP 9540. PERU. LORETO. Bellavista: MUSM 2982.

Bothrocophias microphthalmus-BOLIVIA. COCHABAMBA. Carrasco National Park: CBF 1899; Leche River: MHNC 103, 104. LA PAZ. Pilón Lajas Biosphere Reserve: MNK 1801, 1814. BENI. Rurrenabaque: MNK 493. PERU. CUSCO. Timpia: MUSM 25673, 26443; La Convención: MUSM 26093; Bajo Puyantimari: CORBIDI 10712; Mabe: MUBI 7013; Nusinuscato: MUBI 7458. SAN MARTIN. Tarapoto: MUSM 3066; Paitoja: CORBIDI 1242; Bajo Naranjillo: CORBIDI 3384. JUNIN. Tarma: MUSM 2035. HUÁNUCO. Sira: MUSM 8605; Tingo María: CORBIDI 1464. CAJAMARCA. Cordillera del Cóndor: CORBIDI 1461-63. AMAZONAS. Cordillera del Colán: CORBIDI 2059. MADRE DE DIOS. Huasorocco: MUBI 10871; Amarakaeri Comunal Reserve: MUBI 14345, 14397.

Bothrops alternatus - ARGENTINA. FORMOSA. El Bagual Ecological Reserve: FML 1434. MISIONES. El Bonito: FML 67. CORRIENTES. Yacyretá: FML 2565. ENTRE RÍOS. Salto Grande: MLP 265. SANTA FE. Campo Garay: MACN (exCENAI) 285. SANTIAGO DEL ESTERO. Quimili: FML 2007. CÓRDOBA. Las Rabonas: CZA 138. BUENOS AIRES. Punta Lara: MLP 286; Sierra La Ventana: MLP 749. URUGUAY. Montevideo: MZUSP 1460. BRAZIL. SANTA CATARINA. Taunay: MZUSP 1966. MATO GROSSO DO SUL. Campo Grande: MZUSP 10235. RIO GRANDE DO SUL. Rosario do Sul: MZUSP 1968. GOIÁS. Parque Nacional das Emas: MZUSP 11727. DISTRITO FEDERAL. Brasilia: MTKD 14649.

Bothrops ammodytoides-ARGENTINA. SALTA. Cafayate: FML 1802. CATAMARCA. Andalgalá: FML 1405. LA RIOJA. Castro Barros: FML 7804. TUCUMÁN. Tafí del Valle: FML 1592. CÓRDOBA. Calamuchita: CZA 29. SAN LUIS. Buena Esperanza: MACN 2329. Unknown locality: MTKD 28709. LA PAMPA. Bernasconi: MLP 789. BUENOS AIRES. Bahía Blanca: MLP 787. MENDOZA. Cerro Los Leones: MACN 29051. NEUQUEN. Zapala: FML 9215. RÍO NEGRO. Allen: MACN 3638. CHUBUT. Península de Valdés: MLP 563.

Bothrops asper-BELIZE. Orange Walk: MZUSP 6445.

Bothrops atrox- BOLIVIA. LA PAZ. Madidi: CBF 2347. PANDO. San Silvestre: MNKR 2269. PERU. MADRE DE DIOS. Manu: MUBI 10353. CUSCO. La Convención, Echarate: MUBI 9840. PASCO. Ciudad Constitución: MUSM 20070. LORETO. Loreto: MUSM 22293. BRAZIL. MARANHÃO. Baixada Maranhense: MZUSP 5543. RONDÔNIA. Nova Brasilia: MZUSP 8764. MATO GROSSO. Apiacás: MZUSP 11182. ACRE. Porto Walter: MZUSP 7376. RORAIMA. Rio Catrinami (km 137 Perimetral Norte): MZUSP 6969. PARA. Juruá, Rio Xingu: MZUSP 9413. COLOMBIA. BOLÍVAR. Santa Rosa: MZUSP 6288. CHOCÓ. 100 k S of Bogotá: MHNG 1329.042. CUNDINAMARCA. Bogotá: MHNG 1329.048. META. San Juan de Arama: MHNG 1050.023. TOLIMA. Ibagué: MHNG 2522.026, 2522.028. Armero: MHNG 2522.027.

Bothrops barnetti-PERU. LAMBAYEQUE. Lambayeque: CORBIDI 5618. Las Pampas: MUSM 23684; Corral de Arena: MUSM 23685; Chiclayo: MUSM 3019; Olmos: CORBIDI 1460, 10385-87, 14137.

Bothrops bilineatus-BOLIVIA. SANTA CRUZ. Mataracú: MNK 1429; Amboró National Park: MNK 328. BRAZIL. ESPIRITO SANTO. Santa Teresa: MZUSP 4456. RORAIMA. Serra dos Surucucus: MZUSP 10372. BAHIA. Olivená: MZUSP 13248. COLOMBIA. AMAZONAS. Leticia: MZUSP 3722. ECUADOR. NAPO. Añango: MZUSP 8253. PERU. AMAZONAS. Cordillera del Cóndor: MUSM 21295. LORETO. Pevas: MUSM 2148; Allpahuayo-Mishana National Reserve: MUSM 2611; Ampiyacu River: MZUSP 4398. SAN MARTIN. Tarapoto: MUSM 3084; MUSM 3260.

Bothrops brazili-PERU. AMAZONAS. Condorcanqui: MUSM 18586; Bagua: MUSM 2652. CUSCO. Echerate: MUSM 21748; Kinteroni: MUBI 9833. Porotobango: MUBI 9865, 9868. UCAYALI. Bolognesi: MUSM 20071. MADRE DE DIOS. Ponal: MUBI 10226.

Bothrops chloromelas - PERU. HUANUCO. Tingo María: MUSM 2088. JUNIN. Satipo: MUSM 2005; Huacapistana: MUSM 2003, 2252. PASCO. Oxapampa: MUSM 24747; Chontabamba: MUSM 23680, 24744; Manto: MUSM 18010, 19043; Santa Isabel: MUSM 19174.

Bothrops cf. sonene-BOLIVIA. BENI. Santa Ana de Yacuma: CBF 233, 1554. Unknown locality: ZMH 6678. Bothrops cotiara-ARGENTINA. MISIONES. 2 de Mayo: MLP 882. Frontera Refugio: MACN 12712. BRAZIL. PARANA. Curitiba: MACN 31386; Porto União: MZUSP 2473; Inácio Martins: MZUSP 2467; Tangará: MZUSP 247071. SÃO PAULO. Presidente Epitácio: MZUSP 2468. SANTA CATARINA. Bom Retiro: MZUSP 2505.

Bothrops diporus - ARGENTINA. FORMOSA. Palmar Largo: MLP 5002, 5008; El Espinillo: CZA 128; María Cristina: MLP 5007, 5009; Estero Grande: MACN 44621; Las Lomitas: CZA 79, UNNEC 5677; Paraje Urbana Vieja: UNNEC 56, 
496; Pirané: UNNEC 165; San Pedro: UNNEC 8927; Pozo del Tigre: MACN 44622. CHACO. Resistencia: MLP 5006; Roque Saenz Peña: FML 7397; La Sabana: MACN 44424; Fortin Chaja: MACN 44422; Colonia Benitez: MACN 44425; Las Palmas: MACN 44421; Colonia Las Mercedes: UNNEC 654, 1798-99; Pampa del Infierno: UNNEC 695, 697, 82627; Tacú Pozo: UNNEC 671; Campo Largo: UNNEC 8152, 11328; Nueva Pompeya: UNNEC 9107; Fuerte Esperanza: MLP 5297, UNNEC 1805, 9109, 11033; Roque Sáenz Peña: FML 7397. SANTA FE. Villa Guillermina: UNNEC 11613; Santa Clara: MACN 44359, 44361; Esperanza: MACN 44360, 44367; La Gallareta: MACN 44362. BOLIVIA. TARIJA. Villa Montes: ZFMK 32622-23, 36500-01, 44747, NHM 28409; SANTA CRUZ. Samaipata: ZFMK 57522, 60173, 67052; Río Seco: ZFMK 67052; Pampagrande: ZFMK 67114-16, 75054-57; Mataral: ZFMK 75021; Ángel Sandóval: MNKR 1404; Algodonal: MNKR 4632; Cordillera: MHNC 315. CHUQUISACA. Tomina: CBF 482; Luis Calvo: FML 2388-I. PARAGUAY. BOQUERÓN. Filadelfia: ZFMK 61019, 62523, 37295-98, 37820-21, 38295, 39699-701, 45854, 66324-25, 73524-25, 72878; Loma Plata: ZFMK 46283-84, 46287-89, 50924-25, 53126-27. CAAGUAZÚ. Toledo: MTKD 43459-60. CORDILLERA. San Bernardino: MLP 290.

Bothrops aff. diporus-ARGENTINA. RÍO NEGRO. General Roca: FML 9439. NEUQUEN. Fortín de la Piedra: MLP 1797. MENDOZA. Dr. Gassul: MLP 881. SAN JUAN. Villa Media Agua: FML 782. LA PAMPA. Parque Nacional Lihué Calel: MACN 31383. SAN LUIS. Junín: FML 6952; Alto Pencoso: MLP 271, 272, 1897. CÓRDOBA. Cruz del Eje: CZA 2016; Río Ceballos: CZA 168; La Granja: CZA 205; La Posta: MLP 880; La Calera: CZA 204; Salsipuedes: CZA 173; Diquecito: CZA 170; Río Tercero: CZA 175; Molinari: CZA 180; Yocsina: CZA 208. SANTIAGO DEL ESTERO. Frias: FML 18489; Los Telares: MLP 1575; Sumapampa: MLP 268, 272-73; Pampa Pozo: FML 17893; Caspi Corral: FML 1262; Monte Quemado: FML 2027. TUCUMÁN. Bella Vista: FML 7348; Gobernador Garmendia: MACN 44623-24; Concepción: MACN 44625, FML 13711; La Cocha: MACN 44626, FML 1810; Tafí Viejo: MLP 1563; Buena Vista: FML 7348; Concepción: FML 13711; Trancas: FML 23882. CATAMARCA. Pomán: FML 16127; Tinogasta: FML 1675. LA RIOJA. Chilecito: MACN 1577; Anillaco: FML 9471; Famatina: MLP 108; Chamical: MACN 44357-58. SALTA. Aguas Blancas: FML 2611-12, 16128; General José de San Martín: FML 18065; Santa Victoria: FML 17939. Rio Pescado: FML 627; Rosario de la Frontera: MLP 662, 664; Rivadavia: FML 15764; Urundel: FML 17915; General Güemes: FML 17444; JUJUY. Abra de Mortero: FML 25551; Caimancito: FML 17913; San Salvador de Jujuy: FML 18144; Yuto: FML 267; Unknown locality: NHM 28403/1-/3. BOLIVIA. TARIJA. Reserva Nacional de Flora y Fauna de Tariquía: CBF 2079; Arce: MHNC 310.

Bothrops erythromelas-BRAZIL. BAHIA. Santo Inácio: MZUSP 14047; Queimadas: MZUSP 10550; Sento Sé: MZUSP 15691; Alagoado: MZUSP 14048. Alagoas, Xingó: MZUSP 10881; Guanambi: IBSP 55541; Rio do Antônio: IBSP 79766. PARAÍBA. Patos: MZUSP 7282; Coremas: MZUSP 3550-51.

Bothrops fonsecai-BRAZIL. SÃO PAULO. Serra de Bocaina: MZUSP 1653; Parque Estadual Campos do Jordão: MZUSP 16802.

Bothrops insularis-BRAZIL. SÃO PAULO. Ilha Queimada Grande: MZUSP 1048, 1040.

Bothrops itapetiningae_BRAZIL. Brasilia: MZUSP 13931. SÃO PAULO. Pirassununga: MZUSP 4006; Itapetininga: 1437.

Bothrops jararaca - ARGENTINA. MISIONES. Bernardo de Irigoyen: MACN 33030; Puerto Esperanza: MACN 38731; Montecarlo: MLP 1571; Aristóbulo del Valle: MLP 1812. BRAZIL. PARANÁ. Morretes: FML 2110; Ortigueira: MZUSP 13150. SÃO PAULO. Boracéia: MZUSP 4504. SANTA CATARINA. São Bento do Sul: MZUSP 7572 . RIO DO JANEIRO. Rio do Janeiro: MZUSP 2727. MINAS GERAIS. Vargem Alegre: MZUSP 1426.

Bothrops jararacussu - ARGENTINA. MISIONES. San Pedro: FML 976; Libertad: MACN 35346; El Alcázar: MACN 38669. BRAZIL. SANTA CATARINA. Rio Vermelho: MZUSP 9533. SÃO PAULO. Estação Ecologica da Juréia: MZUSP 10560. RIO DE JANEIRO. Baixada Fluminense: MZUSP 2316.

Bothrops jonathani-ARGENTINA. JUJUY. Santa Bárbara: FML 1050. SALTA. La Caldera: FML 570; Santa Victoria: FML 1480. BOLIVIA. SANTA CRUZ. San Juan del Potrero: MNKR 1618, 2036; Valle Grande: MNKR 718. COCHABAMBA. Quillacollo: CBF 2673. TARIJA. Curqui: CBF 2318-20; Quebrada Loray: MHNC 206-07. Samaipata: ZFMK 57523, 58160, 60172.

Bothrops leucurus - BRAZIL. BAHIA. Salvador: MZUSP 2769, 2770; 30 km W Itaberaba: MZUSP 7800; Ilhéus: MZUSP 9623.

Bothrops lutzi-BRAZIL. PIAUI. Valença: MZUSP 5855, 5859; Parque Nacional Serra da Capivara: MZUSP 12842; Baixa Grande do Ribeiro: MZUSP 12536. TOCANTINS. Reserva Serra Geral do Tocantins: MZUSP 15005. BAHIA. Jaborandi: MZUSP 18703.

Bothrops marmoratus-BRAZIL. MINAS GERAIS. São Roque de Minas: MZUSP 15006, 15067-68; Serra do Salitre: BSP73286. GOIÁS. Ipameri: IBSP 55056; DF. Brasilia: IBSP 21590.

Bothrops mattogrossensis-BRAZIL. MATO GROSSO DO SUL. Miranda: IBSP 24489; Bodoquena: MZUSP 12872; Aquidauana: IBSP 13591; Corumbá: IBSP 19077.

Bothrops aff. mattogrossensis 1- BRAZIL. MATO GROSSO. Porto Estrela: MZUSP 15048. Chapada dos Guimarães: MZUSP 11849, 11851; Jangada: IBSP 86481.

Bothrops aff. mattogrossensis 2-BRAZIL. TOCANTINS. Peixe: MZUSP 15546, 15681; Guaraí: MZUSP 12679; Salvador do Tocantins: MZUSP 17871.

Bothrops aff. mattogrossensis 3-BRAZIL. GOIÁS. Santa Rita do Araguaia: MZUSP 9914; Jataí: MZUSP 3781; Mineiros: MZUSP 11730, 12145-46, 15065.

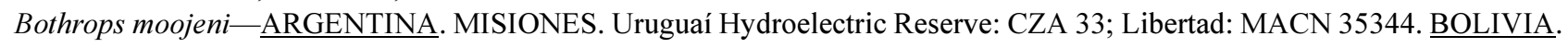


SANTA CRUZ. Noel Kempff Mercado National Park: MNKR 156, 610. BRAZIL. SÃO PAULO. São Jose do Rio Preto: MZUSP 14213. MATO GROSSO. Claudia: MZUSP 11236. BAHIA. Maracujá, Santa Rita de Cássia: MZUSP 3665.

Bothrops neuwiedi-BRAZIL. SÃO PAULO. Angatuba: MZUSP 4917, IBSP 5555; Itu: IBSP 70337, 70723; Sorocaba: IBSP 71611; Santo André: IBSP 73292; Votorantin: IBSP 73637; Areias: IBSP 74218; Santana de Parnaíba: IBSP 75357. MINAS GERAIS. Baependi: IBSP 74563-66, IBSP 88757, MZUSP 17793; Três Corações: IBSP 71102; Machado: IBSP 74040; Aiuruoca: IBSP 71063; Munhoz: IBSP 72925, IBSP 73477; São Vicente de Minas: IBSP 73004-06; Andradas: IBSP 73007.

Bothrops aff. neuwiedi-BRAZIL. MINAS GERAIS. UHE Fumaça: MZUSP 15724; Serra do Cipó: MZUSP 7567, 17979; Santana do Riacho: IBSP 81110; Serra do Caraça: MZUSP 5249; Conselheiro Mata: MZUSP 8120; Pedra Menina: MZUSP 9044; Mariana: MZUSP 15724; Jabuticatubas: MZUSP 17979.

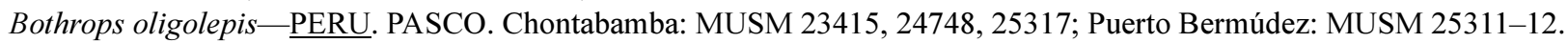

Bothrops pauloensis-BRAZIL. MINAS GERAIS. Frutal: IBSP 58550, IBSP 71110-11; Águas de Santa Barbara: IBSP 89772; Prata: IBSP 71473-74.

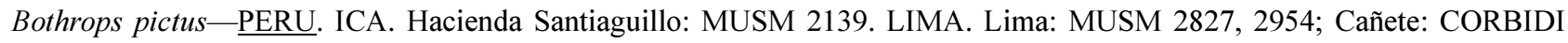
3650, 10384. La Molina: MUSM 27292; Jicamarca: MUSM 2433, 2365, 2536; Tornamesa: MUSM 25395; Lachay: MUSM 2705; Valle de Lurin: MZUSP 2755. ANCASH. Recuay: MUSM 25397. Huarmey: CORBIDI 425, $10382-83$.

Bothrops pubescens-URUGUAY. TACUAREMBÓ. Pozo Hondo: MZUSP 5874.

Bothrops aff. pubescens-ARGENTINA. MISIONES. Isla Yacyertá: UNNEC 7089; San Javier: MACN 45849; Iguazú: MACN 44426; San Ignacio: MLP 1598; San Antonio: UNNEC 6023; General Belgrano: FML 26354-55; Puerto Leoni: UNNEC 11760. ENTRE RÍOS. Colonia Cerrito: MACN 44370. CORRIENTES. San Roque UNNEC 193; Mburucuyá: UNNEC 4830, 4994, 7335; Isla Apipé: UNNEC 10127, 10192, 10197, 10198-99, 10415, 10422-23, 10522-23, 10956, 10958; Ituzaingó: UNNEC 128, 459; San Luis de Palma: UNNEC 141; San Lorenzo: UNNEC 7030; Monte Grande: UNNEC 9793, 10133; Santa Ana: UNNEC 7940; Santa Teresa: UNNEC 4928; Laguna Cambá: UNNEC 10362; Garruchos: UNNEC 6177; Centinela: UNNEC 6748. BRAZIL. PARANA. Cascavel: IBSP 42474. SANTA CATARINA. Campo Erê: IBSP 29766; Chapecó IBSP 51448; Itapiranga: IBSP 27137. RIO GRANDE DO SUL. Tuparendi: IBSP 59629.

Bothrops pulchra-PERU. AMAZONAS. Bagua Grande: MUSM 2902.

Bothrops sanctaecrucis-BOLIVIA. BENI. Oromomo: CBF 1009, 1023. COCHABAMBA. Carrasco, Yuquis: CBF 776, 673; Chapare, Guacharos: MHNC 358. SANTA CRUZ. Potrerillo del Guenda: MNK 518, 633, 839; Yapacaní: MNK 248, 358; San Carlos: MNK 226; Amboró National Park: MNK 359, 619.

Bothrops taeniatus_-PERU. CUSCO. Timpia: MUSM 25674. HUÁNUCO. Sira: MUSM 8606. JUNÍN. Satipo: MUSM 2006. BRAZIL. PARÁ. Serra de Kukoinhokren: MZUSP 11575. MATO GROSSO. Apiacás: MZUSP 11183; Claudia: MZUSP 111253-54.

Bothrops venezuelensis - VENEZUELA. YARACUY. Nirgua: MZUSP 7830.

Cerrophidion godmani-GUATEMALA. SANTIAGO SACATEPÉQUEZ. Santiago Sacatepéquez: MUSM 2574. CHIMALTENANGO. Quisaché: MZUSP 6477.

Crotalus durissus terrificus-ARGENTINA. CÓRDOBA. Cañada de Luque: CZA 170. MISIONES. San Vicente: MACN 36869. BOLIVIA. CHUQUISACA: CBF 02462. SANTA CRUZ. Mataral: MNK 2150.

Lachesis muta-BOLIVIA. LA PAZ. Alto Madidi: CBF 1935; Tumupasa: CBF 1723; San Ignacio: CBF 740, 2127. BENI. Oromomo: CBF 1024. PERU. CUSCO. Tambopata: MUSM 7376, 7377.

Porthidium nasutum —ECUADOR. ESMERALDAS. San Miguel: MZUSP 7480. 


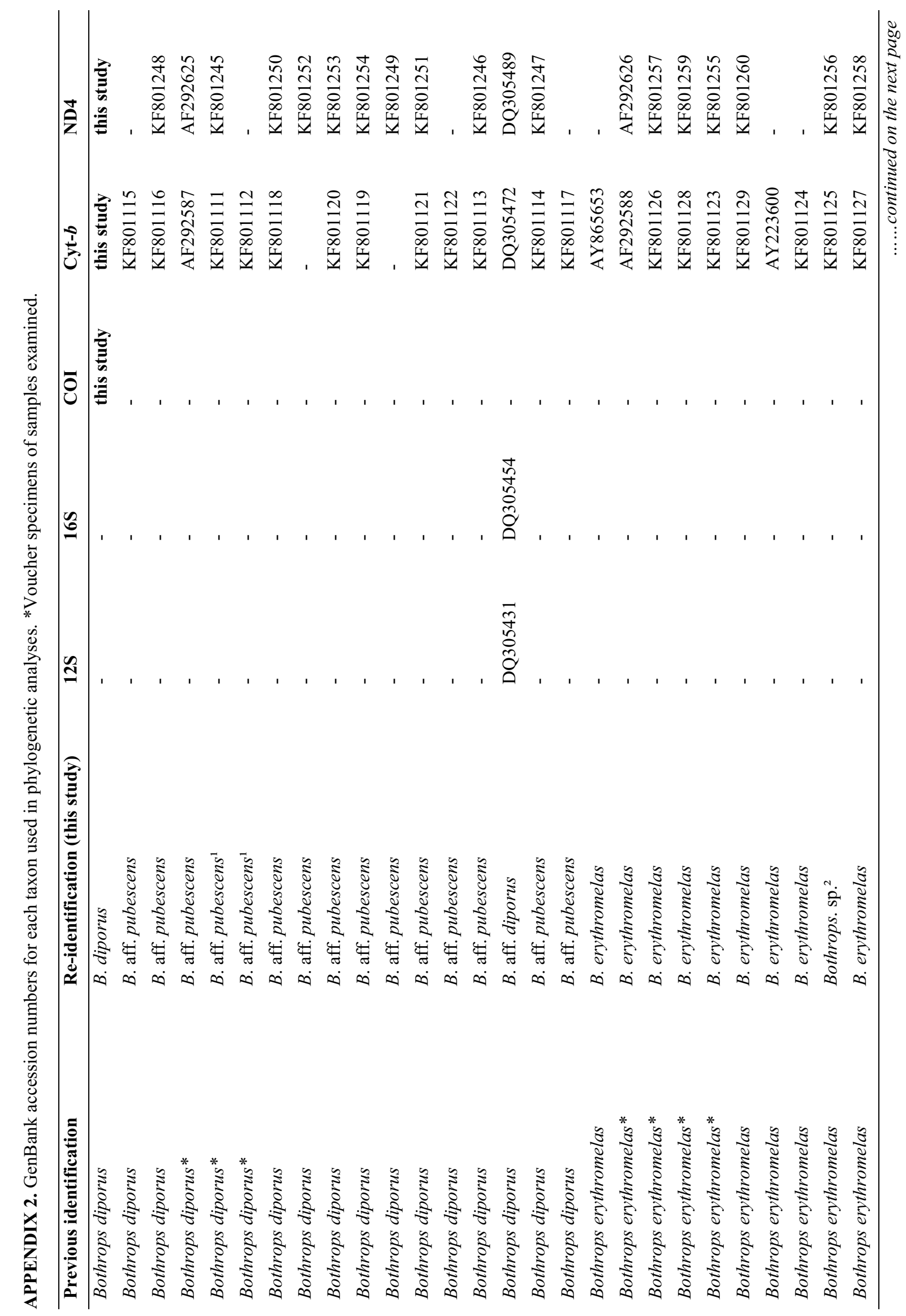




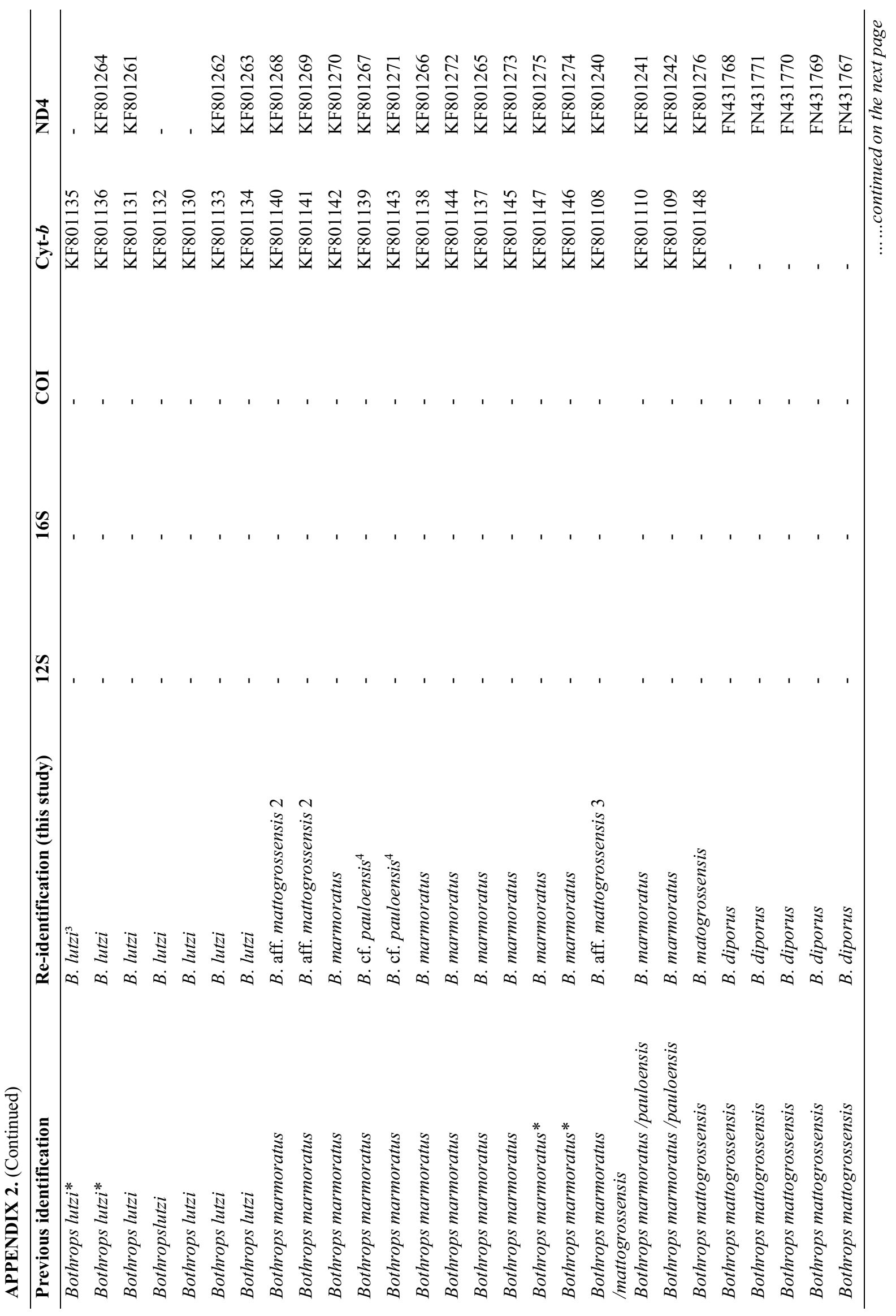




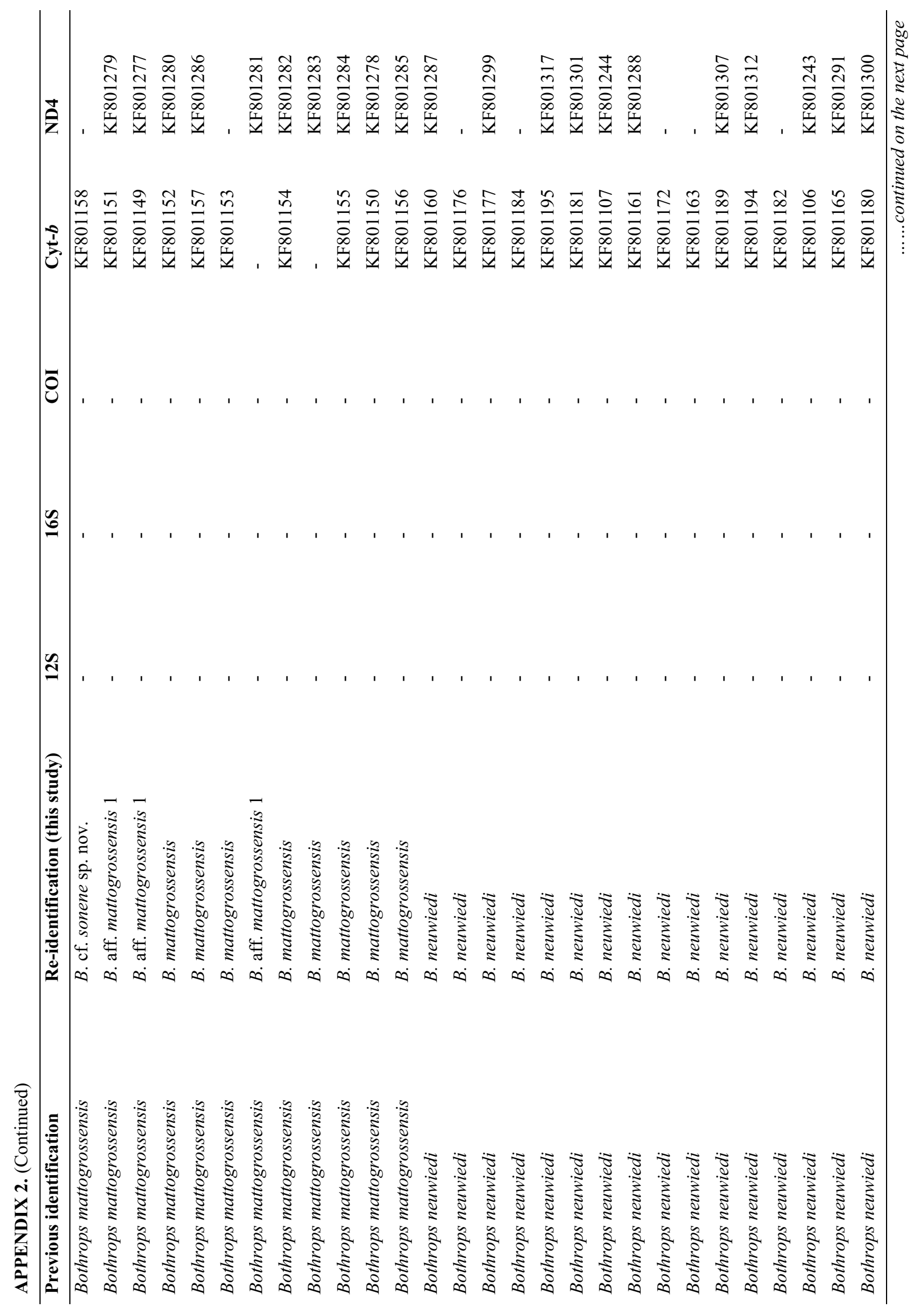




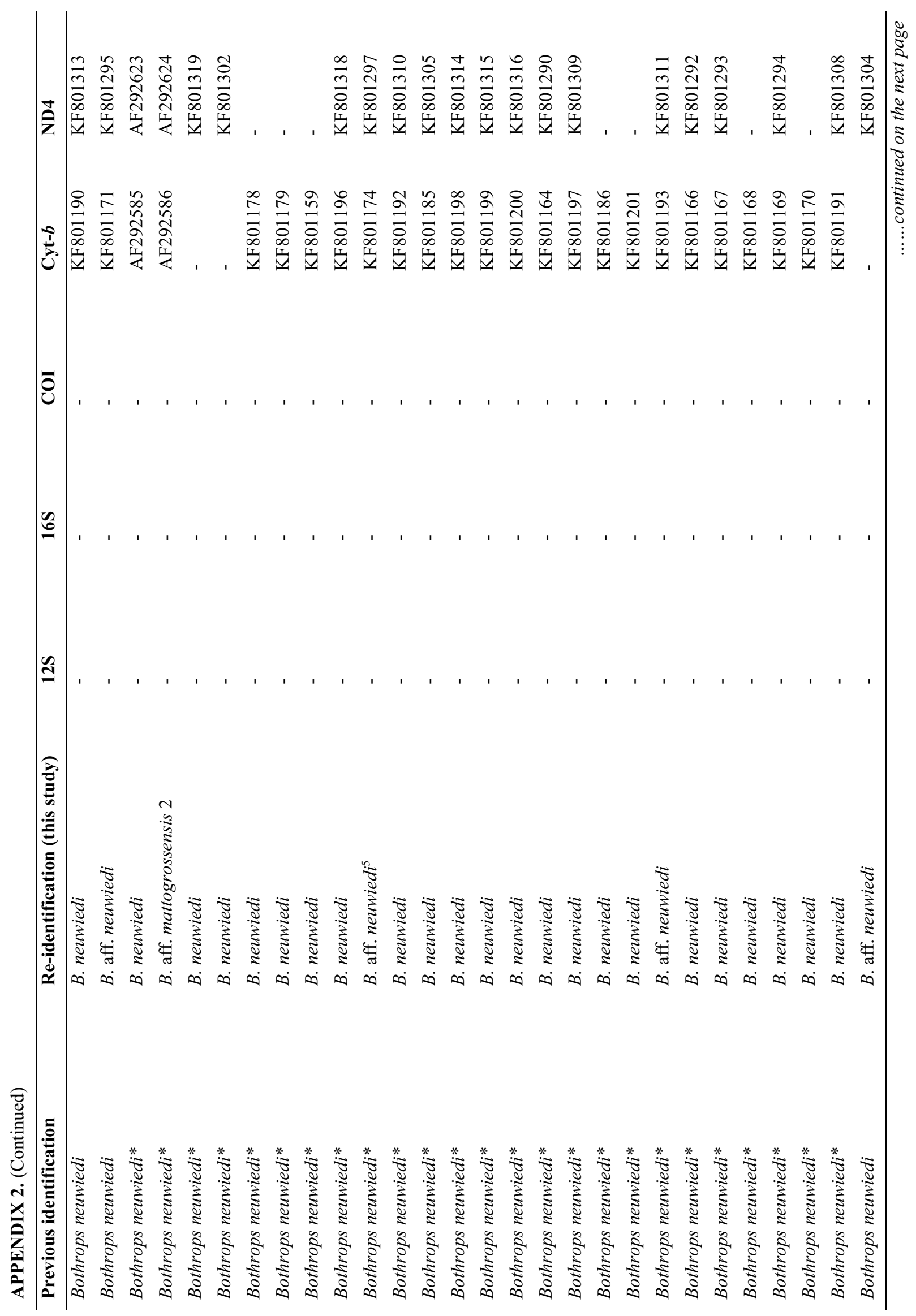




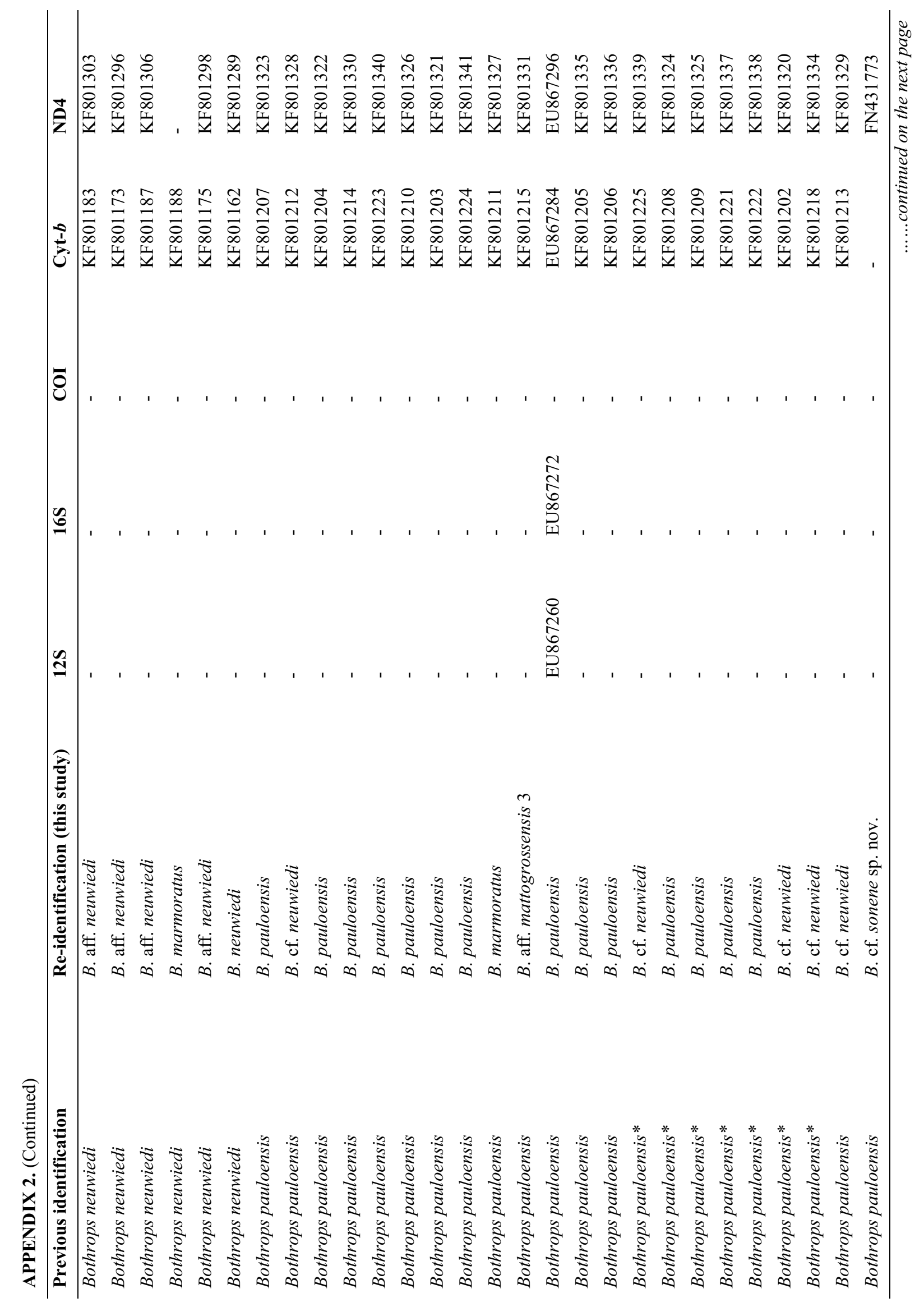




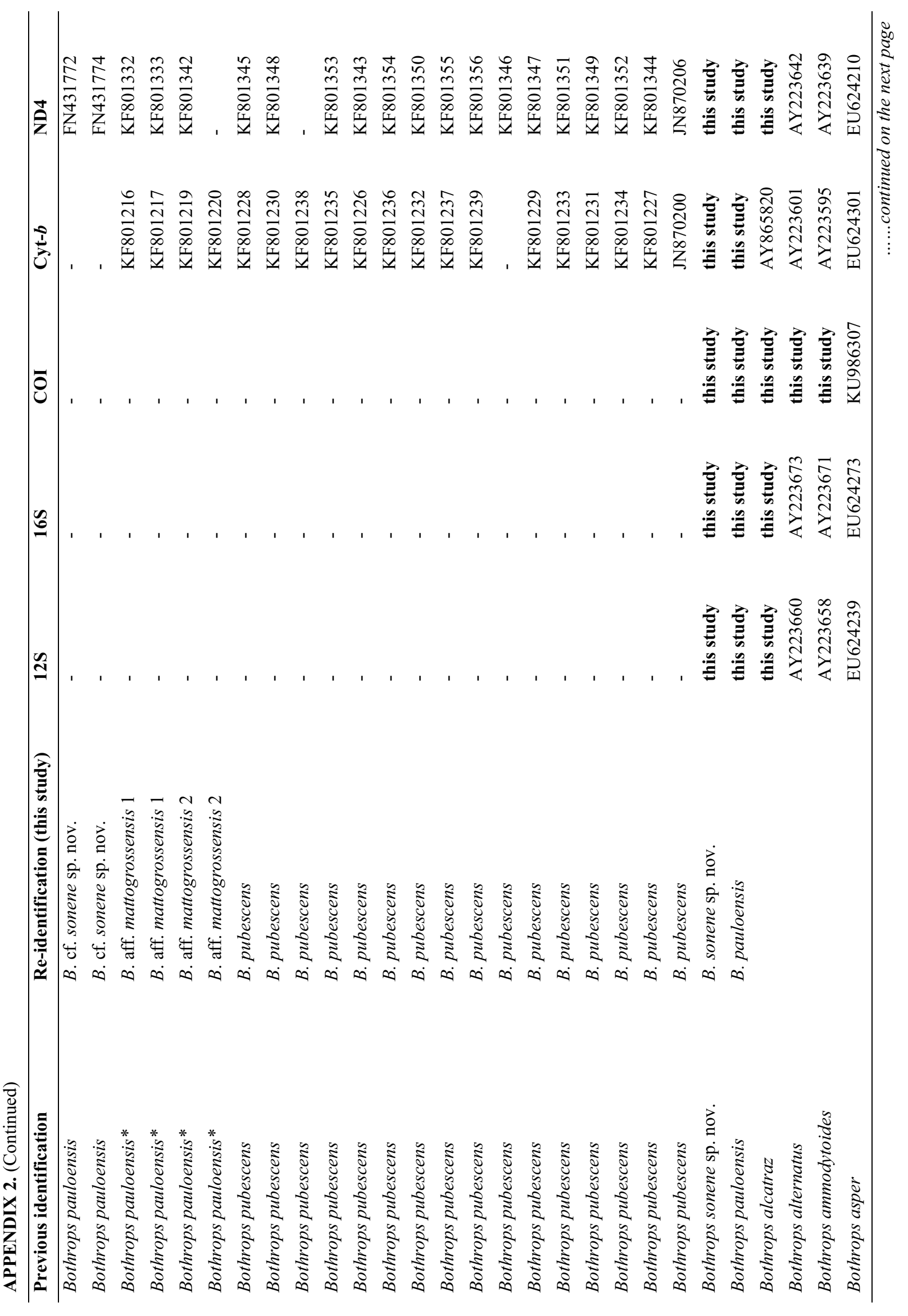




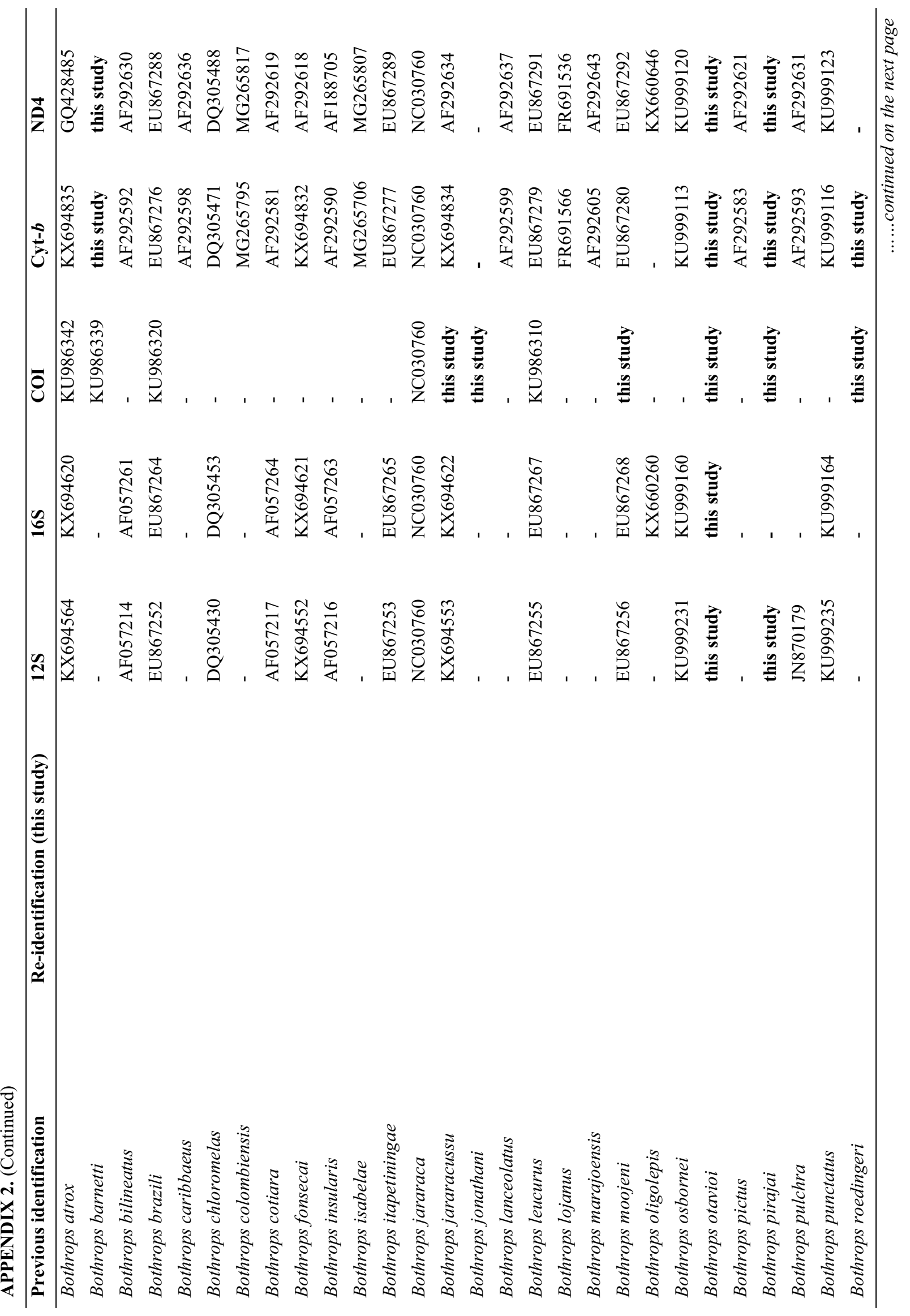




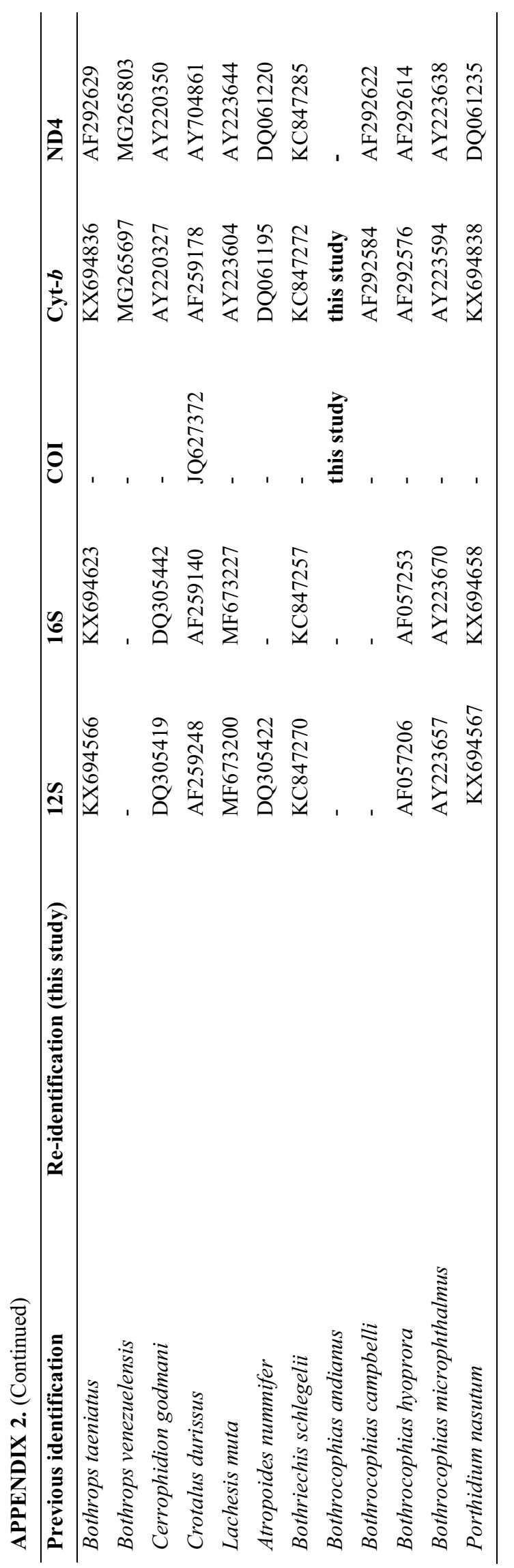

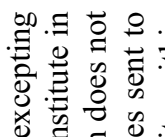

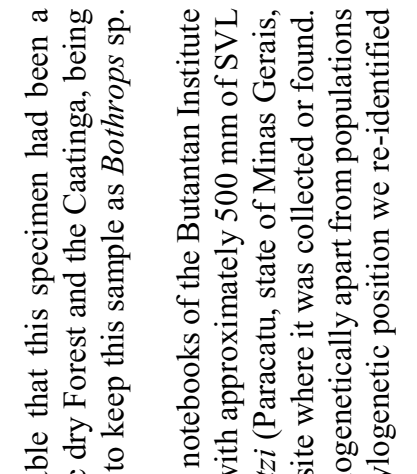

.

0 政?

言焉的造

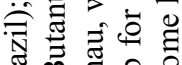

ติ

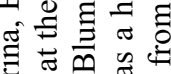

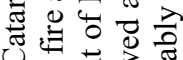

Uु

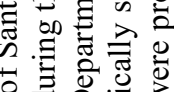

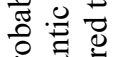

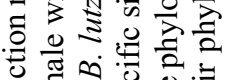

\% 0

若焉离

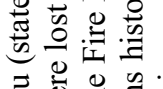

$\pm \cong$

可)

离解

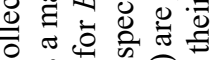

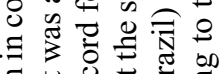

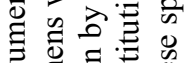

范

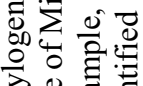

存语部

焉 恶

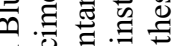

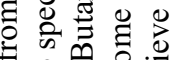

$\infty$

चี

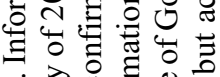

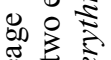

娄全导宂

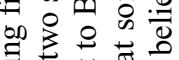

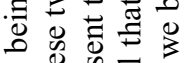

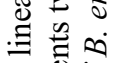

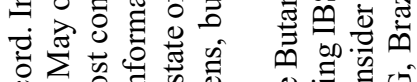

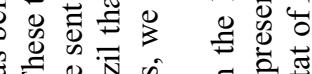

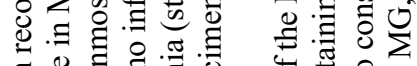

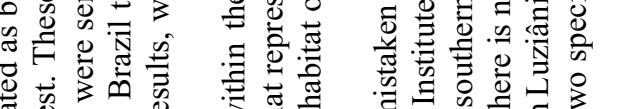

능

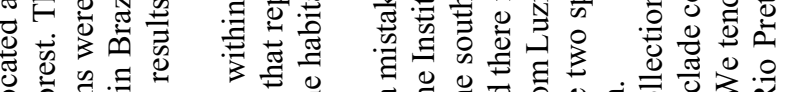

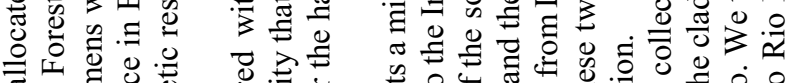

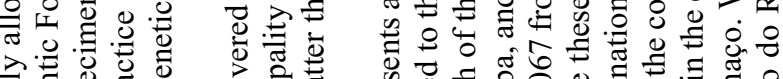

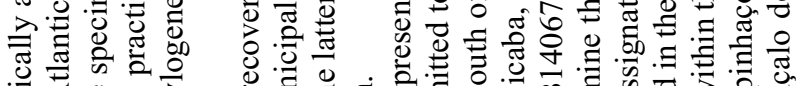

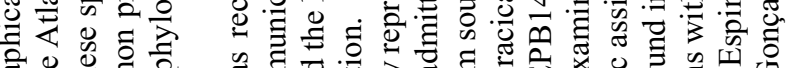

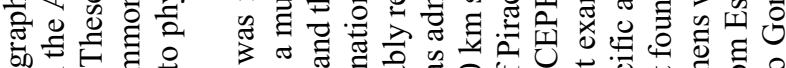
贻.

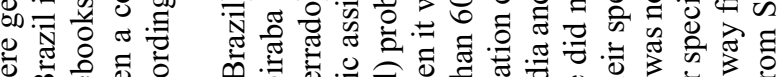

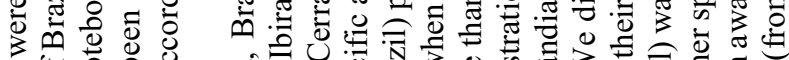

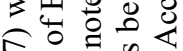

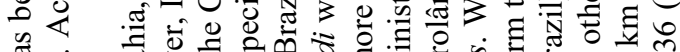

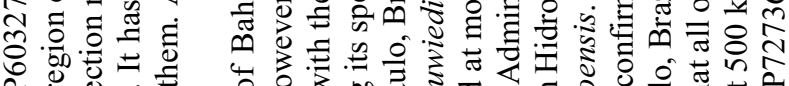

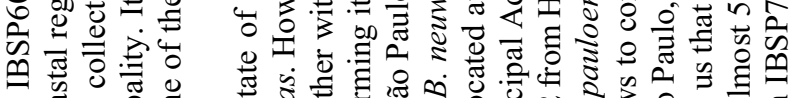

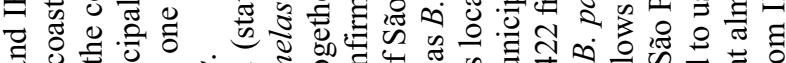

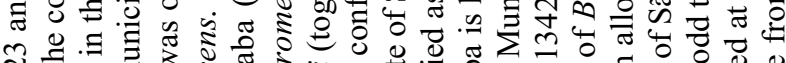

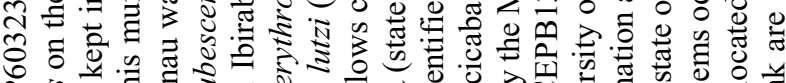

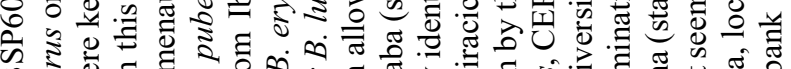

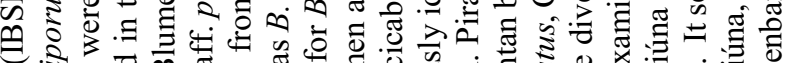

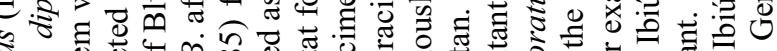

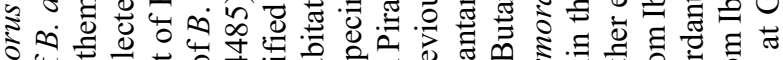

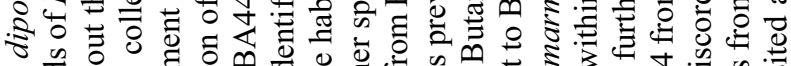

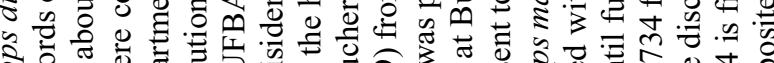

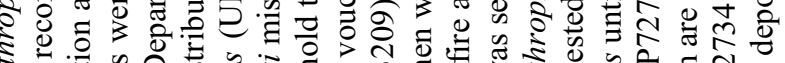
ธำ

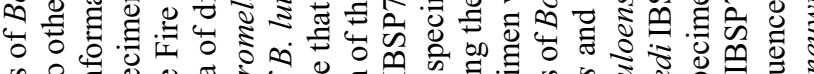

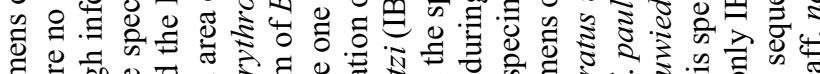

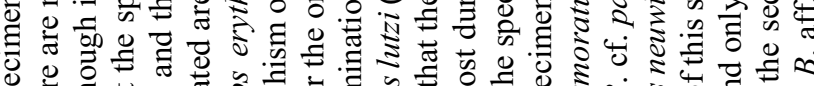

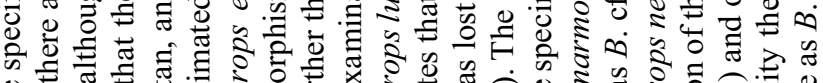

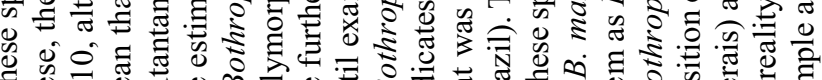

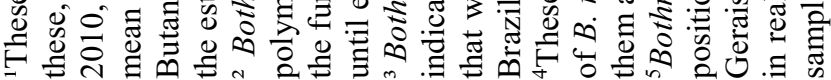


APPENDIX 3. Morphological characters used in phylogenetic analyses. * Characters adapted from Carrasco et al. (2012). ** Characters adapted from Silva \& Rodrigues (2008). ***Characters defined in this study. Characters 52 and 58 were coded only for Bothrocophias and Bothrops. Characters 49-51 and 53-55 were coded only for the species of the $B$. neuwiedi group. All characters were coded as non-additive. Characters 50-53 and 55 were coded as non-additive and additive, but results were the same under both coding. For those characters involving counts of both sides of the body, we included, when possible, counts from the left side.

$0 \ldots \quad \mathrm{N}^{0}$ of scales between internasals $* * *$

1_ $\quad \mathrm{N}^{0}$ of loreals $* * *$

$2 \quad \mathrm{~N}^{\mathrm{o}}$ of ventrals

3 . $\mathrm{N}^{\mathrm{o}}$ of intersupraoculars

4_ $\quad \mathrm{N}^{\circ}$ of scales contacting supraoculars

5_ $\mathrm{N}^{\mathrm{o}}$ of supralabials

$6 \quad \mathrm{~N}^{\circ}$ of infralabials

7_ $\quad \mathrm{N}^{\mathrm{o}}$ of canthals

8 - $\mathrm{N}^{\mathrm{o}}$ of postcanthals

$9 \quad \mathrm{~N}^{\circ}$ of anterior intercanthals $* * *$

$1 \overline{0} \mathrm{~N}^{\mathrm{o}}$ of medial intercanthals

11_ $\mathrm{N}^{\mathrm{o}}$ of posterior intercanthals $* * *$

$12-\mathrm{N}^{\mathrm{o}}$ of prefoveals

$13 \mathrm{~N}^{\circ}$ of subfoveals

$14^{-} \mathrm{N}^{\mathrm{o}}$ of postfoveals

$15 \mathrm{~N}^{\circ}$ of suboculars

16 - $\mathrm{N}^{\mathrm{o}}$ of postoculars

17 N $\mathrm{N}^{\mathrm{o}}$ of interoculabials between suboculars and $3^{\text {rd }}-4^{\text {th }}$ supralabials $* * *$

$18 \ldots \mathrm{N}^{\mathrm{o}}$ of interoculabials between suboculars and $4^{\text {th }}$ supralabial

$19 \mathrm{~N}^{\mathrm{o}}$ of interoculabials between suboculars and $4^{\text {th }} 5^{\text {th }}$ supralabials $* * *$

$20 \mathrm{~N}^{\mathrm{o}}$ of sublacunals $* * *$

21 No of dorsocephalic scales from the snout to the neck, longitudinally $* * *$

22 - $\mathrm{N}^{\mathrm{o}}$ of interrictals

23_ $\mathrm{N}^{\mathrm{o}}$ of gulars

$24 \mathrm{~N}^{\mathrm{o}}$ of middorsal scales rows

25 Distance between the eye and the anterior end of the head/length of the head

26_ Interorbital distance/maximum width of the head

27 Internostril distance/width of the head

28 Length of caudal spine/caudal length

29 Postorbital stripe height (scored as $n^{\text {o }}$ of scales at the level of $5^{\text {th }}-6^{\text {th }}$ supralabials)

30 Postorbital stripe length (scored as $\mathrm{n}^{\circ}$ of scales posteriorly from the rictus) $* * *$

31_ $\mathrm{N}^{\mathrm{o}}$ of supralabials encroached on by postorbital stripe

32 - $\mathrm{N}^{0}$ of infralabials encroached on by postorbital stripe $* * *$

33 Inferior/superior margins of mid-dorsolateral blotch **

34_ Height of mid-dorsolateral blotch **

35_ Minimum space between mid-dorsolateral blotches $* *$

36 - $\mathrm{N}^{\mathrm{o}}$ of dorsolateral blotches $* * *$

37_ Width of the parietal/length of the parietal

38 . Minimum width across both frontals/length of the frontal

39_ Minimum width across both frontals/width of the parietal

40 Length of the basisphenoid/length of the skull

41_ Length of the mandible/length of the skull

42 Length of maxillary fang/height of maxilla

43 _ Length of the ectopterygoid/length of base of the pterygoid

44 ${ }^{\circ}$ of dentary teeth

$45_{-} \mathrm{N}^{\mathrm{o}}$ of pterygoid teeth

46 $\mathrm{N}^{\mathrm{o}}$ of palatine teeth

47_ Length of hemipenial body (measured from the base of the organ to the bifurcation of the lobes)/total hemipenial length (measured from the base of the organ to the tips of the lobes) *

48 _ Length of capitulum (measured ventrally on the lobes) /length of hemipenial lobe (measured from the bifurcation of the lobes to the tip of the lobes) *

49 Shape of internasals $(0)$ rounded, (1) oval ***

$50_{-}^{-}$Ventral markings (0) immaculate, (1) heavily speckled in all the ventral region, (2) heavily speckled in the lateroventral region, (3) slightly speckled in the lateroventral region, (4) very slightly speckled in the lateroventral region to almost 
inmmaculate $* * *$

51 Gular coloration (0) strongly pigmented, (1) slightly pigmented, (2) immaculate ***

52 - Ventral margin of postorbital stripe starts (0) posterior, (1) below, (2) anterior to the orbit

53 - Pair of parietal blotches in the head (0) absent, (1) rounded, (2) elongated posteriorly ***

54 _ Pair of occipital blotches $(0)$ elongated posteriorly beyond the neck, (1) elongated posteriorly to the neck ***

55 Superior portion of dorsolateral blotches (0) rectangular, (1) subtriangular, (2) rounded ***

56_ Markings on gulars (0) absent, (1) diffused markings, (2) conspicuous stripes

57 Distinct white spots on posterior infralabials and gulars (0) absent, (1) present

58_- Dorsal color pattern (0) trapezoidal "Bothrocophias microphthalmus-type" markings, (1) rectangular "Bothrops ammodytoides-type" markings, (2) C-shaped "B. alternatus-type" markings, (3) trapezoidal "B. neuwiedi-type" markings, (4) trapezoidal "B. jararaca-type" markings, (5) trapezoidal "B. jararacussu-type" markings, (6) banded "B. taeniatustype" markings, (7) trapezoidal "B. atrox-type" markings *

59 Green body coloration (0) absent, present (1)

60_ Supraoculars (0) oval, (1) rounded, (2) elongated *

61_ Middle preocular $(0)$ not in contact with the orbit, (1) in contact with the orbit

62 - Upper preocular (0) does not contribute, (1) contributes to the canthus rostralis

63 Lower preocular (0) not in contact, (1) in contact with the orbit ***

64_ Prelacunal (0) discrete, (1) fused with second supralabial *

65_ Prelacunal discrete (0) in contact with third supralabial, (1) in contact with second supralabial, (2) separated from second supralabial *

66_ Subfoveals (0) incomplete row, (1) complete row *

67 Loreal (0) not elongated, (1) elongated

68 Internasals ( 0$)$ not elongated, (1) elongated

$69+$ Rostral (0) triangular or subtriangular, (1) quadrangular, (2) trapezoidal

70 _ Rostral (0) not elevated, (1) elevated

$71_{-}^{-}$Canthus rostralis $(0)$ not elevated, (1) elevated to form a distinct ridge

72 Intersupraoculars (0) smooth or slightly keeled, (1) keeled

73 Canthorostrals $(0)$ absent, (1) present

74_ Canthals (0) same size or slightly smaller than internasals, (1) bigger than internasals and rounded, (2) bigger than internasals and elongated *

75 Intercanthals $(0)$ smooth or slightly keeled, (1) keeled $* * *$

76 _ Upper preocular (0) entire, (0) divided

$77_{-}^{-}$Tuberculate keels on mid-posterior dorsal scales (0) absent, (1) present

78 _ Middle preocular and supralacunal (0) fused, (1) not fused

79 _ Lowest preocular and sublacunal (0) not fused, (1) partially or totally fused

80 Intersupraocular fusions in plate-like scales (0) absent, (1) usually present

81_ Subcaudals (0) entire, (1) entire and divided, (2) divided *

82_ Body compressed laterally (0) absent, (1) present ***

83_ Rattle (0) present, (1) absent

84_ Hemipenis (0) U-shaped and lobes well separated, (1) not U-shaped and lobes close to each other

85_ Lobes of the hemipenis (0) subcylindrical, (1) cylindrical, (2) fusiform *

86_ Orientation of hemipenial lobes (0) parallel, (1) divergent

87_ Distribution of hemipenial spines (0) heterogeneous, (1) homogeneous *

88_ Big sized spines in the hemipenis (0) absent, (1) positioned distally, (2) positioned proximally

89_ Hemipenial spines: (0) straight or curved; (1) hooked

$90 \_$Intralobular spines (0) absent, (1) distally in the intralobular area, (2) along the intralobular area *

91_ Microornamentation in the capitulum (0) in all calyces, (1) in half or more of the calyces, (2) in the basal calyces, (3) absent

92_ Microornamentation in the ventral surface of the hemipenial body (0) in all the surface, (1) in part of the surface

93_ Microornamentation in the dorsal surface of the hemipenial body (0) in part of the surface, (1) in all the surface, (2) absent

94 Microornamentation in the intrasulcar area (0) absent, (1) present

95_ Swollen dorsal area in hemipenial body (0) absent, (1) present

96_ Swollen dorsal area in hemipenial body (0) well developed, (1) poorly developed

97_ Lateral depression in hemipenial body (0) absent, (1) present

98_ Lateral depression in hemipenial body (0) developed in both sides of the body, (1) developed in one side of the body, (2) poorly developed in one side of the body

99_ Swollen dorsal area in the intralobular area (0) absent, (1) present $* * *$

100_Posterolateral edges of dorsal surface of parietal: (0) with more or less pronounced shelf along the edges; (1) with poorly developed shelf in the posteriormost portion of the edge; (2) absent *

101_Anterior end of the supratemporal: (0) in contact or close to parietal; (1) separated from parietal 
102_Internal lateral margin of the supratemporal: (0) straight; (1) curve

103_Posterior end of the supratemporal: (0) with internal and external lateral processes; (1) with external lateral process; (2) with internal lateral process *

104_Supraoccipital crests: (0) in contact or close to parietal; (1) separated from parietal

105_Anterior portion of the basisphenoid: (0) not sharpened; (1) sharpened

106_Crest of the basisphenoid: (0) uniformly elevated; (1) with a rounded differentiated elevation

107_Mandibular crest: (0) symmetric; (1) asymmetric

108 Medial wall of pit cavity in maxilla: (0) well developed; (1) weakly developed or absent

109_Choanal process of palatine: (0) positioned anteriorly; (1) positioned medially; (2) positioned posteriorly

110_Size of choanal process of palatine: (0) reduced; (1) moderate; (2) attenuate

111_Posterior lateral margin of ectopterygoid: (0) straight; (1) convex

112_Projection of ectopterygoid at point of articulation with pterygoid: (0) weakly differentiated; (1) well differentiated

113_Prootic foramina for nerves V2 and V3: (0) separated by bony partition; (1) not separated by bony partition

114_Foramen in ventral surface of lateral process of prootic: (0) absent; (1) present

115_Ventral process of basioccipital: (0) single; (1) bifurcates distally

116_Supratemporal: (0) rounded dorsal surface; (1) flat dorsal surface *

117_Angular and splenial: (0) partially or totally fused; (1) not fused*

\section{APPENDIX 4. Morphological matrix.}

$\&[$ cont $]$

Crotalus durissus $0.4001 .3360 .490-0.537 \quad 0.024-0.3100 .281-0.635$ 1.026-1.196 1.000-1.333 0.210 0.000 0.0000 .0000 .000

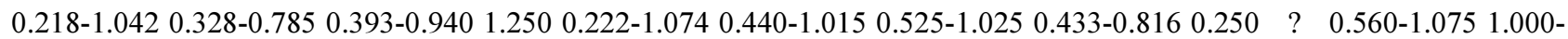
1.2650 .5950 .0000 .6210 .4760 .0000 .0000 .0010 .0040 .010 ? ? ? ? 0.7550 .8270 .4440 .5000 .8050 .4770 .4930 .200 $0.0000 .3100 .000-0.1621 .000-1.015$

Lachesis muta $\quad 0.8001 .119-2.537$ 0.973-1.045 1.288-1.570 0.802-0.975 0.227-0.476 0.816-1.183 0.000-1.920 1.000 1.000

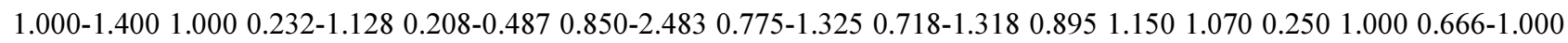

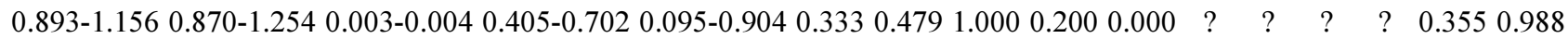
1.1850 .0550 .8000 .6720 .3920 .4000 .0000 .3100 .3020 .000

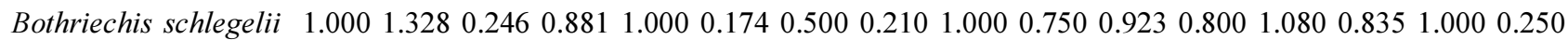

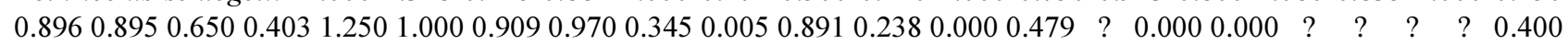
$0.7930 .7030 .2770 .8280 .0000 .1770 .9000 .7500 .810 \quad$ ? ?

Porthidium nasutum 0.4000 .3360 .0380 .5950 .8330 .3220 .5000 .2100 .5000 .5000 .7690 .7000 .6800 .5570 .3331 .2500 .896 $\begin{array}{lllllllllllllllllll}0.895 & 1.150 & 0.736 & 0.250 & 0.352 & 0.363 & 0.000 & 0.345 & 0.005 & 0.675 & 0.285 & ? & 0.599 & 0.5330 .800 & 0.333 & ?\end{array} ?$ 0.4440 .5000 .8400 .3360 .6580 .0000 .2500 .0600 .7440 .062

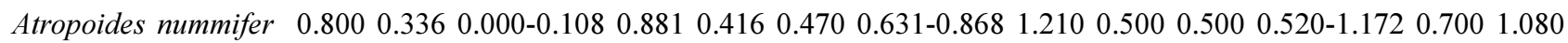

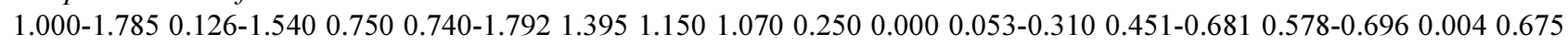
0.4761 .0000 .3590 .1330 .0000 .000 ? ? ? ? $0.5111 .0220 .9990 .6110 .8800 .2830 .6830 .6000 .5000 .310 \quad ? \quad$ ?

Cerrophidion godmani $1.000 \quad 0.336 \quad 0.0160 .7380 .666 \quad 0.470 \quad 0.500 \quad 0.210 \quad 0.000 \quad 0.500 \quad 0.7690 .500 \quad 0.080 \quad 0.278 \quad 0.3330 .750$ 0.8960 .3950 .1500 .4031 .2500 .3520 .0000 .4850 .179 ? ? ? ? 0.3590 .4000 .2000 .000 ? ? ? ? ? ? ? ? 0.0080 .4430 .600 ? 0.560 ? ?

Bothrocophias hyoprora 1.0000 .3360 .1470 .7380 .8330 .0260 .1661 .2100 .5000 .6250 .7690 .7000 .8800 .2780 .3330 .250

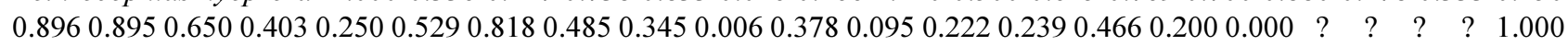
1.1830 .6290 .1660 .8050 .2920 .4680 .6000 .3330 .5600 .2550 .578

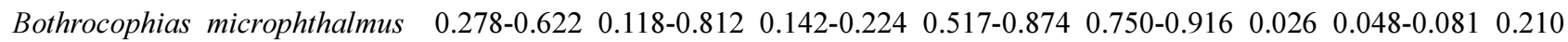
0.390-0.720 0.421-0.613 0.563-0.783 0.500-0.717 0.482-1.144 0.175-0.548 0.333 0.100-0.800 0.733-1.355 0.385-0.905 0.040$0.4450 .203-0.5460 .100-1.0700 .500-0.754 \quad 0.500-0.8120 .231-0.597 \quad 0.080-0.3710 .004-0.008$ 0.459-0.783 0.285-0.523 0.111$0.2220 .251-0.4670 .525-0.6240 .258-0.4420 .333$ ? ? ? ? $0.688-0.8440 .264-1.0680 .277-0.5920 .166-0.9440 .702-$ 0.862 0.247-0.274 0.392-0.696 0.579-0.721 0.264-0.735 $0.8100 .186-0.3950 .375-0.453$

Bothrocophias andianus $0.030-0.3100 .336$ 0.388-0.533 0.560-0.845 0.783-0.921 0.000-0.069 0.095-0.316 0.210 0.390-0.720 $0.397-0.560 \quad 0.567-0.875 \quad 0.463-0.702 \quad 0.260-0.5660 .041-0.058 \quad 0.250-0.550 \quad 0.145-0.5700 .8960 .295-0.5850 .050-0.2200 .126-$ $0.4500 .080-0.500 \quad 0.445-0.708 \quad 0.394-0.6400 .590-0.8940 .111-0.3760 .004-0.008$ 0.000-1.270 0.476-0.809 0.111-0.444 0.527$0.7480 .474-0.8370 .410-0.6400 .333$ ? ? ? ? $0.466-0.6440 .632-0.9990 .481-0.8140 .166-0.2220 .720-1.0170 .026-$ $0.2300 .316-0.6320 .345-0.9880 .583-0.9160 .687-1.2650 .3720 .484$

Bothrops lojanus $\quad 0.042-0.2420 .336 \quad 0.219-0.250 \quad 0.680-1.0820 .750 \quad 0.0260 .166 \quad 0.2100 .5000 .448-0.8010 .7690 .459-0.741$ $\begin{array}{lllllllllllllll}0.280 & 0.058-0.337 & 0.000 & 0.250 & 0.896 & 0.395 & 0.150 & 0.403 & 0.250 & 0.622-0.788 & 0.690-0.946 & 0.613-0.843 & 0.345 & 0.004-0.006 & 0.783-\end{array}$

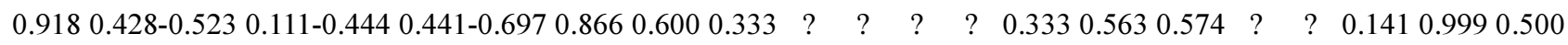
0.4160 .5600 .2790 .593

Bothrops pictus $\quad 0.050-0.150 \quad 0.3360 .307-0.461 \quad 0.431-0.7600 .750 \quad 0.140-0.652$ 0.431-0.901 0.130-1.290 0.460-1.040 0.345$0.4880 .426-0.9580 .302-0.764 \quad 0.330-0.5300 .000 \quad 0.530-1.4700 .625-1.1250 .8960 .3950 .1500 .403 \quad 0.250 \quad 0.492-0.742 \quad 0.662-$ 
$\begin{array}{llllllllllllll}0.837 & 0.676-0.941 & 0.345 & 0.003 & 0.432-0.810 & 0.285-0.428 & 0.333-0.555 & 0.661-0.937 & 0.685-1.091 & 1.000 & 0.920-1.303 & ?\end{array} ?$

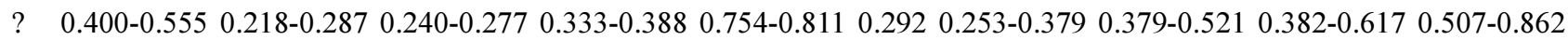
0.1390 .562

Bothrops ammodytoides $0.038-0.064$ 0.336 0.239-0.365 0.860-1.188 0.675-0.818 0.329-0.502 0.556-0.833 0.930-1.740 0.450$0.7600 .375 \quad 0.800-1.103 \quad 0.600 \quad 0.362-0.782 \quad 0.233-0.348 \quad 0.263-0.470 \quad 0.850-1.425 \quad 1.125-1.7770 .300-0.555 \quad 0.160-0.6750 .403$ $1.2500 .399-0.5120 .618-0.9590 .650-0.8910 .263-0.5050 .007-0.0120 .567-0.8640 .380-0.9520 .444-1.2220 .762-0.9400 .406-$

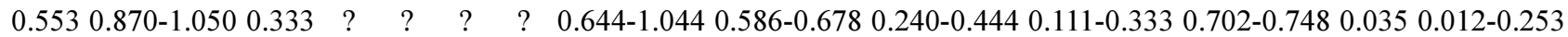
$0.209-0.3240 .174-0.2700 .3100 .325-0.5110 .343-0.578$

Bothrops jonathani $\quad 0.042-0.048 \quad 0.000-1.110 \quad 0.324-0.428 \quad 1.117-1.502 \quad 0.715-0.895 \quad 0.406-0.693 \quad 0.781-1.040 \quad 0.040-1.000$ $0.390-0.7950 .750 \quad 0.790-1.1260 .700 \quad 0.604-2.0180 .618-1.523 \quad 0.493-1.9500 .910-1.6701 .022-1.9110 .895-1.395 \quad 0.735-1.335$ 0.843-1.130 1.060-1.900 0.705 0.970-1.308 0.676-0.941 0.639-0.885 0.003-0.007 0.567-0.891 0.285-0.666 0.444-1.000 1.000$1.2970 .389-0.5440 .492-0.6420 .333$ ? ? ? ? $\quad 0.600-0.9110 .494-0.8500 .407-0.5920 .277-0.5000 .771-0.8340 .194-$ $0.3710 .240-0.5690 .245-0.3830 .083-0.2500 .000-0.1900 .860-1.0690 .218-0.468$

Bothrops alternatus $0.000 \quad 0.336 \quad 0.426-0.538 \quad 0.000-1.102 \quad 0.715-0.902 \quad 0.278-0.393 \quad 0.678-1.051 \quad 0.210 \quad 0.395-0.765 \quad 0.437-$ 0.687 0.813-1.110 0.775-0.875 0.726-1.540 0.370-1.222 0.276-1.006 0.550-1.325 0.755-1.681 0.895 0.505-0.860 0.736 1.250 $0.8230 .858-1.195 \quad 0.676-1.004 \quad 0.872-1.175 \quad 0.002-0.008$ 0.405-0.891 0.285-0.761 0.333-0.888 0.776-1.057 0.361-0.489 0.664$0.8361 .000-1.333$ ? ? ? ? $0.666-0.800 \quad 0.000-0.8620 .000-0.5740 .111-0.5000 .731-0.8910 .345-0.4860 .126-0.303$ $0.209-0.3240 .3330 .0600 .813-1.0230 .468-0.656$

Bothrops cotiara $0.022-0.2180 .336$ 0.343-0.385 1.185-1.720 0.542-0.690 0.174 0.341-0.525 0.210 0.375-0.825 0.500 0.813$1.0320 .800 \quad 0.372-0.828 \quad 0.139-0.863 \quad 0.430-1.0700 .125-0.575 \quad 1.155-1.8220 .895 \quad 0.6500 .7361 .250 \quad 0.705 \quad 0.766-1.3060 .478-$ $0.7500 .345-0.6800 .004-0.007$ 0.675-1.000 0.666-0.761 0.777-0.888 0.750-1.167 0.412-0.521 0.484-0.816 0.106-0.393 ? ? ? ? $\quad 0.7110 .9190 .5740 .4440 .8510 .3620 .1260 .3000 .3330 .3100 .627-0.8130 .328-0.390$

Bothrops fonsecai 0.0000 .3360 .4541 .3100 .5830 .1740 .1660 .2101 .0000 .6250 .9230 .7000 .6800 .0000 .6660 .2500 .896 0.245-0.995 0.000-0.755 0.403 0.250 0.764 0.909 0.647 0.595 0.006 0.837 0.666 0.555 0.8390.4001.000 0.333？？？ 0.9330 .5860 .3510 .3330 .8110 .3360 .2910 .3000 .5000 .3100 .5580 .375

Bothrops itapetiningae $0.000 \quad 0.336 \quad 0.101-0.222 \quad 0.704-0.868 \quad 0.646-0.742 \quad 0.1740 .3330 .2100 .5000 .6250 .7690 .7000 .280-$

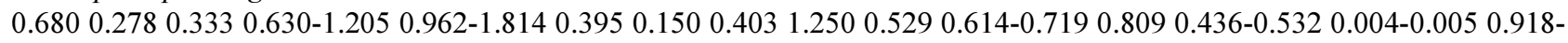
$1.1081 .0000 .333-0.6660 .7190 .5331 .0001 .000 \quad ? \quad ? \quad ? \quad ? \quad 0.4220 .4020 .3880 .555 \quad ? \quad 0.4770 .8730 .0000 .000 \quad$ ? 0.5110 .609

Bothrops sonene sp. nov. 0.000 0.336 0.445-0.486 0.738 0.737-0.929 0.174 0.196-0.470 0.210 0.125-0.375 0.490-0.635 0.660$\begin{array}{llllllllllll}0.955 & 0.485-0.715 & 0.630-0.830 & 0.278 & 0.096-0.736 & 0.210-0.790 & 0.711-1.451 & 0.520-1.020 & 0.110-0.690 & 0.403 & 0.250 & 0.363-0.499\end{array}$ 0.522-0.613 0.472-0.660 0.326-0.615 0.003-0.007 0.189-0.918 0.047-1.047 0.555-0.888 0.467-0.582 0.184-0.416 0.550-0.750 0.250-0.583 0.000-1.215 0.405-1.202 0.398-0.588 1.551-2.038 ? ? ? ? ? ? ? ? ? ? 0.2550 .515

Bothrops cf. sonene $0.000 \quad 0.336 \quad 0.475-0.552 \quad 0.668-0.998 \quad 0.732-0.850 \quad 0.139-0.309 \quad 0.293-0.485 \quad 0.210 \quad 0.045-0.620 \quad 0.500$

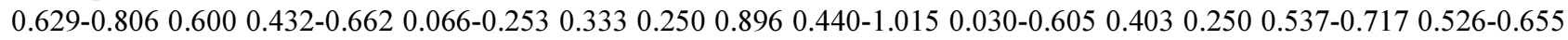
0.500-0.686 0.478-0.713 0.999 0.513-1.135 0.380-0.571 0.666-0.777 0.455-0.705 0.386-0.525 0.552-0.782 0.363-0.746 0.9072.323 0.376-1.492 0.049-0.552 1.619-1.853 ? ? ? ? ? ? ? ? ? ? ? ?

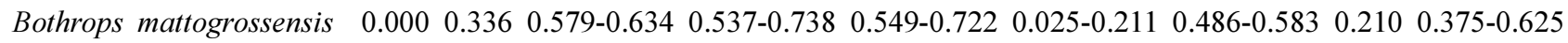
0.406-0.468 $0.603-0.692 \quad 0.418-0.500 \quad 0.522-0.780 \quad 0.050-0.278 \quad 0.050-0.333 \quad 0.210-0.5000 .340-0.7110 .355-0.6450 .110-0.400$

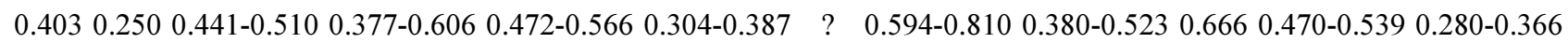
0.650-0.750 0.333 0.676-1.430 1.256-1.560 0.256-0.842 0.375-0.624？？？？？？？？？？？

Bothrops aff. mattogrossensis_1 $0.000 \quad 0.336 \quad 0.381-0.471 \quad 0.494-0.768 \quad 0.600-0.8150 .063-0.211 \quad 0.196-0.470 \quad 0.210 \quad 0.500$ 0.312-0.562 0.429-0.724 0.418-0.582 0.278-0.782 0.022-0.300 0.083-0.416 0.250 0.896 0.395 0.110-0.690 0.403 0.250 0.293$0.4410 .318-0.500 \quad 0.352-0.6180 .210-0.4810 .001-0.0090 .405-0.9450 .142-0.8090 .333-0.6660 .419-0.6590 .366-0.5000 .370-$ 0.830 0.250-0.583 0.600-1.123 0.212-2.299 0.575-1.398 0.032-0.708？？？？？？？？？？？

Bothrops aff. mattogrossensis_2 $0.000 \quad 0.336 \quad 0.305-0.382 \quad 0.375-0.701 \quad 0.570-0.6620 .034-0.196 \quad 0.085-0.3810 .2100 .500$ 0.343-0.456 0.476-0.815 0.435-0.525 0.352-0.688 0.013-0.041 $0.016-0.383 \quad 0.230-1.0700 .8960 .3950 .1500 .4030 .2500 .217-$ $0.3470 .269-0.4210 .461-0.6390 .238-0.3860 .008-0.0100 .675-0.8910 .428-0.666 \quad 0.444-0.6660 .398-0.6330 .304-0.3760 .458-$ $0.7420 .3330 .753-1.2610 .632-1.4920 .059-0.3350 .551-1.048 \quad ? \quad ? \quad ? \quad ? \quad$ ? ? ? ? ? ? 0.3480 .421

Bothrops aff. mattogrossensis_3 $0.000 \quad 0.336 \quad 0.442-0.530 \quad 0.670-0.902 \quad 0.592-0.740 \quad 0.069-0.2790 .250-0.683 \quad 0.210 \quad 0.410-$

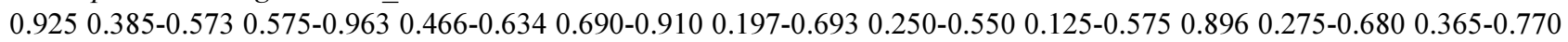
0.343-0.686 0.250 $0.380-0.600 \quad 0.487-0.6400 .4850 .2200 .005-0.0100 .729-0.8100 .476-0.6660 .333-0.5550 .470-0.6090 .358-$ $0.4410 .418-0.6480 .3330 .769-1.1230 .642-1.2270 .486-1.0750 .218-0.619$ ？？？？？？？？？？？？

Bothrops diporus 0.000 0.336 0.489-0.628 0.627-0.987 0.694-0.872 0.142-0.281 0.396-0.691 0.210 0.320-0.595 0.345-0.555 0.520-0.749 $0.417-0.623 \quad 0.480-1.0300 .116-0.540 \quad 0.233-0.600 \quad 0.100-0.650 \quad 0.600-1.155 \quad 0.505-0.995 \quad 0.210-0.7000 .340-0.650$

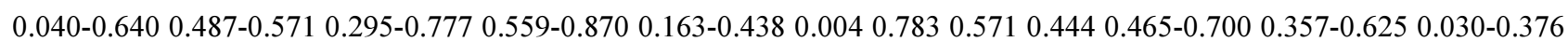
$0.066-0.1601 .338-5.676 \quad 0.502-1.792 \quad 0.138-0.710 \quad 0.611-1.375 \quad 0.444-0.688 \quad 0.287-0.5280 .277-0.518 \quad 0.166-0.222 \quad 0.725-0.765$ 0.274-0.389 0.278-0.392 0.476-0.591 0.272-0.560 0.310 0.069-0.186 0.437-0.546

Bothrops aff. diporus $0.000 \quad 0.336 \quad 0.512-0.690 \quad 0.675-1.058 \quad 0.662-0.863 \quad 0.161-0.386 \quad 0.415-0.696 \quad 0.100-0.350 \quad 0.350-0.655$ 0.450-0.693 0.561-0.930 0.593-0.836 0.496-1.124 0.122-0.615 0.233-0.700 0.120-0.695 0.681-1.059 0.570-1.035 0.310-0.765 $0.390-0.893 \quad 0.000-1.000 \quad 0.580-0.8650 .410-0.850 \quad 0.621-0.9910 .198-0.5380 .1710 .0270 .0000 .666 \quad 0.434-0.7600 .282-0.614$ 
0.044-0.234 0.053-0.080 1.030-4.876 0.531-1.869 $0.016-0.618 \quad 0.768-1.590 \quad 0.577 \quad 0.2520 .4440 .222 \quad 0.7600 .2740 .3920 .500$ $0.5830 .5600 .116-0.3250 .468$

Bothrops aff. pubescens 0.000 0.336 0.466-0.602 0.671-1.048 0.622-0.795 0.116-0.321 0.356-0.615 0.210 0.385-0.640 0.536$0.7130 .478-0.764$ 0.551-0.729 0.440-0.962 0.103-0.562 0.236-0.626 0.160-0.405 0.659-1.192 0.510-1.005 0.240-0.720 0.353$0.7200 .000-0.900 \quad 0.464-0.7820 .278-0.7180 .525-0.8230 .175-0.5250 .004-0.0070 .513-0.8370 .238-0.6190 .444-0.6660 .429-$ 0.688 0.373-0.609 0.040-0.308 0.060-0.160 1.507-6.784 0.512-1.618 0.082-0.773 0.406-1.208？？？？？？？ ? ? ?

Bothrops pubescens 0.0000 .3360 .4320 .8810 .7500 .1740 .5000 .2100 .5000 .5000 .7690 .5000 .4800 .2780 .6660 .2500 .896 $\begin{array}{lllllllllllllllllllll}0.395 & 0.650 & 0.736 & 0.250 & 0.764 & 0.636 & 0.647 & 0.512 & ? & 0.621 & 0.571 & 0.666 & 0.419 & 0.400 & 0.400 & 0.333 & 1.599 & 1.739 & 0.000 & 0.799\end{array}$ 0.4000 .5280 .425 ? $\quad$ ? 0.5920 .2400 .4000 .1660 .3100 .2550 .640

Bothrops neuwiedi 0.000 0.336 0.396-0.489 0.854-1.290 0.565-0.684 0.066-0.578 0.418-0.803 0.210 0.380-0.955 0.500-0.750

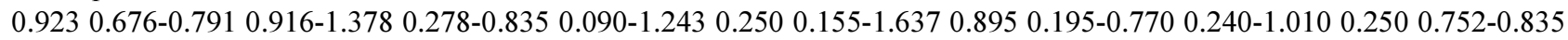

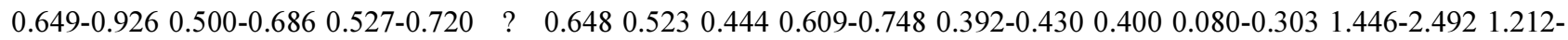
2.425 0.184-1.187 0.193-0.782 0.444 0.379 $0.4070 .3330 .0000 .4420 .8480 .6000 .3330 .3100 .232-0.5580 .343-0.359$

Bothrops aff. neuwiedi $0.000 \quad 0.336 \quad 0.482-0.596 \quad 0.840-1.208 \quad 0.561-0.7710 .158-0.3160 .308-0.6910 .2100 .380-0.7600 .470$ $0.680-0.858 \quad 0.517-0.740 \quad 0.382-0.9200 .050-0.5060 .056-0.5160 .250 \quad 0.511-1.0740 .415-0.9500 .390-0.7700 .366-0.7230 .010-$ $0.7700 .564-0.695 \quad 0.512-1.0460 .512-0.7360 .456-0.6860 .002-0.0080 .540-0.8640 .428-0.7140 .333-0.5550 .446-0.6830 .333-$ 0.457 0.408-0.622 0.333 0.323-3.769 1.338-2.415 0.542-0.937 0.329-1.103 ? ? ? ? ? ? ? ? ? ? ? ? Bothrops marmoratus $0.000 \quad 0.336 \quad 0.309-0.5420 .738$ 0.565-0.684 0.174 0.131-0.368 0.210 0.395-1.105 0.323-0.676 0.366-

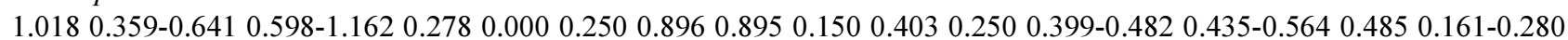

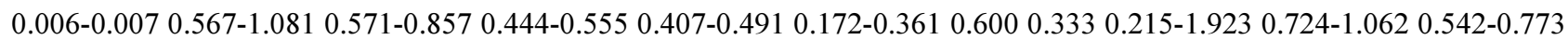
$0.234-0.896$ ? ? ? ? ? ? ? ? ? ? ? ?

Bothrops pauloensis $0.000 \quad 0.336 \quad 0.474-0.6290 .680-1.082 \quad 0.666 \quad 0.353 \quad 0.465-0.701 \quad 0.210 \quad 0.395-1.105 \quad 0.500 \quad 0.769 \quad 0.500$

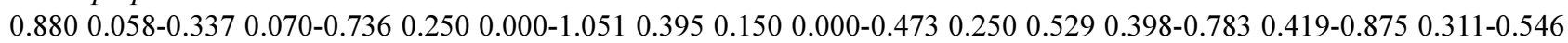
0.003-0.005 0.702-0.918 0.523-0.666 0.555-0.666 0.407-0.491 0.320-0.413 0.358-0.642 0.333 1.015-1.200 1.178-1.695 1.000$1.4670 .000-0.662$ ? ? ? ? ? ? ? ? ? ? ? ?

Bothrops erythromelas $0.000 \quad 0.336 \quad 0.206-0.3310 .310 \quad 0.565-0.725 \quad 0.137-0.2850 .035-0.4650 .2100 .500 \quad 0.218-0.3430 .244-$ $0.6780 .159-0.4410 .116-0.4440 .069-0.208 \quad 0.083-0.4160 .625-1.125 \quad 0.807-1.9180 .020-0.5200 .1500 .043-0.4300 .2500 .164-$ $\begin{array}{llllllllllllllll}0.277 & 0.008-0.112 & 0.289-0.600 & 0.000-0.191 & ? & 0.648-0.972 & 0.619-0.761 & 0.888 & 0.824-1.033 & 0.368-0.521 & 0.800 & 0.666 & 0.799-\end{array}$

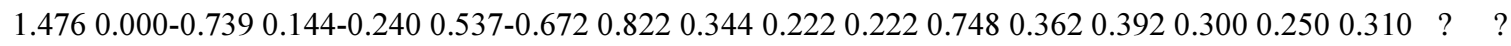

Bothrops lutzi $\quad 0.000 \quad 0.336 \quad 0.332-0.410 \quad 0.274-0.702 \quad 0.299-0.534 \quad 0.174 \quad 0.298-0.5350 .210 \quad 0.500 \quad 0.323-0.6760 .583-0.801$ $\begin{array}{llllllllllll}0.479-0.621 & 0.638-0.922 & 0.220-0.615 & 0.333 & 0.250 & 0.896 & 0.000-0.500 & 0.150 & 0.000-0.473 & 0.010-1.160 & 0.340-0.424 & 0.235-0.491\end{array}$

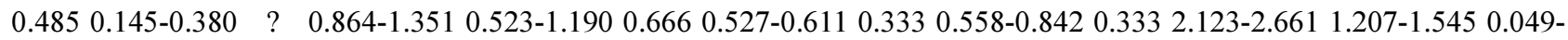
$0.2790 .961-1.457$ ? ? ? ? ? ? ? ? ? ? ?

Bothrops jararaca $0.400 \quad 0.3360 .613-0.702$ 0.828-1.124 0.687-1.034 0.174 0.235-0.486 0.210 0.500 0.375 0.563-0.821 0.700 $\begin{array}{lllllllllllllll}0.480-0.880 & 0.000 & 0.333 & 0.250 & 0.474-1.074 & 0.395 & 0.150 & 0.403 & 0.250 & 0.529 & 0.700-1.390 & 0.611-1.006 & 0.332-0.692 & 0.002-0.006\end{array}$ $\begin{array}{lllllllllllll}0.594-0.891 & 0.380-0.619 & 0.333-0.555 & 0.455-0.623 & 0.400 & 0.410-0.630 & 0.083-0.416 \quad ? \quad ? & ? & 0.600 & 0.597 & 0.499 & 0.388\end{array}$ 0.7880 .6370 .5440 .8000 .6660 .5601 .0460 .281

Bothrops insularis $0.400 \quad 0.3360 .563-0.640$ 0.565-0.768 0.732-0.850 0.174 0.035-0.298 0.210 0.395-1.105 0.375 0.461 0.500 $\begin{array}{llllllllllllllll}0.238-0.522 & 0.000 & 0.333 & 0.250 & 0.000-1.051 & 0.395 & 0.150 & 0.403 & 0.250 & 0.588 & 0.508-0.764 & 0.613-0.843 & 0.311-0.546 & 0.005 & 0.837\end{array}$ 0.6660 .3330 .4790 .0660 .4000 .333 ? ? ? ? 0.5770 .4130 .3141 .0551 .0000 .3890 .6070 .2000 .6660 .8100 .1390 .296 Bothrops taeniatus 0.4000 .336 1.016-1.121 0.512-0.964 0.875-1.041 0.026 0.226-0.506 0.210 0.145-0.855 0.373-0.688 0.506$0.7240 .375-0.4750 .086-0.9540 .069-0.1810 .170-0.763 \quad 0.125-0.575 \quad 0.711-1.3770 .270-0.7200 .1500 .320-0.6530 .2500 .740-$ $\begin{array}{lllllllllll}0.906 & 0.411-0.788 & 0.451-0.762 & 0.390-0.735 & 0.002-0.005 & 0.081-1.162 & 0.142-0.714 & 0.111-0.444 & 0.338-0.491 & 0.066-0.533 & 0.400\end{array}$ $\begin{array}{lllllllllllllllllll}0.333 & \text { ? ? ? } & 0.000 & 0.183 & 0.499 & ? & ? & 0.999 & 0.481 & 0.700 & 0.583 & 0.810 & 0.255-0.465 & 0.515-0.531\end{array}$

Bothrops pulchra $0.400 \quad 0.3360 .4860 .5950 .8330 .0260 .0000 .2100 .5000 .3750 .4610 .3000 .6800 .0000 .3330 .2500 .155$ $0.3950 .1500 .4030 .2500 .4700 .3630 .6470 .0120 .0061 .0270 .7140 .1110 .7190 .4000 .0000 .000 \quad ? \quad$ ? ? ? ? ? ? ? ? ? ? ? ? ?

Bothrops chloromelas $0.400 \quad 0.336 \quad 0.541-0.727 \quad 0.554-0.851 \quad 0.780-0.920 \quad 0.026 \quad 0.130-0.2760 .2100 .500 \quad 0.375 \quad 0.358-0.598$

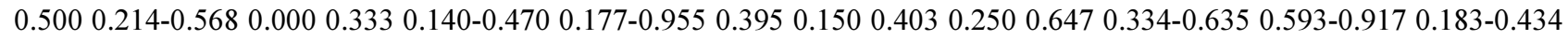
$\begin{array}{llllllllllllll}0.002-0.014 & 0.486-0.972 & 0.142-0.523 & 0.111 & 0.599 & 0.333 & 0.400 & 0.000 & ?\end{array}$ ? ? $\quad 0.466-0.9330 .275-0.8040 .222-0.888$ 0.333-0.388 0.754-0.811 0.256-0.513 0.253-0.379 0.538-0.962 0.430-0.902 0.757-1.112 0.069 0.640

Bothrops oligolepis 0.400 0.336 0.695-0.760 0.727-0.892 0.982-1.100 0.026 0.208-0.375 0.210 0.500 0.250 0.335-0.587 0.400 0.116-0.444 $0.000 \quad 0.196-1.136 \quad 0.000-1.000 \quad 0.837-1.6960 .395 \quad 0.150 \quad 0.0700 .250 \quad 0.5290 .480-0.655 \quad 0.634-0.822 \quad 0.328-0.488$ 0.004-0.005 0.702-0.891 $0.380-0.6660 .0000 .4790 .133$ ? 0.000 ? ? ? ? 0.5770 .6550 .7030 .4440 .7880 .3090 .177 $0.6000 .7501 .060 ?$ ?

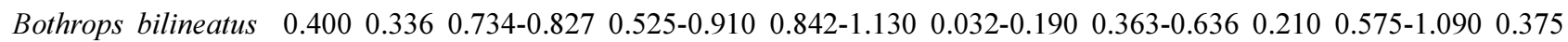
0.489-0.741 $0.500 \quad 0.334-1.026 \quad 0.220-0.615 \quad 0.250-0.550 \quad 0.250 \quad 0.748-1.4660 .395 \quad 0.1500 .4030 .2500 .7640 .668-1.0970 .461-$ $\begin{array}{llllllllllllllll}0.833 & 0.610-0.890 & 0.003-0.007 & 0.729-1.108 & 0.190-0.571 & 0.000-0.222 & 0.119 & 0.000 & 0.200 & 0.333 & ?\end{array}$ 0.2590 .3330 .6970 .4770 .0001 .0000 .8330 .8100 .3950 .281

Bothrops sanctaecrucis $\quad 0.358-0.534 \quad 0.336 \quad 0.532-0.642$ 0.601-0.808 0.647-0.837 0.091-0.207 0.216-0.366 0.210 0.375-0.875 


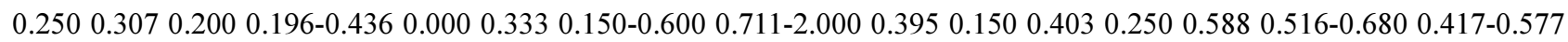
0.279-0.528 0.002-0.009 0.405-0.540 0.380-0.857 0.444 0.359 ? $0.4000 .333 \quad$ ? ? ? ? $0.355-0.6880 .482-0.5170 .537-$ 0.740 0.000-0.777 0.731-0.845 0.159-0.637 0.354-0.632 0.576-0.691 0.515-0.707 0.187-0.765 0.209 0.562

Bothrops brazili $0.032-0.166 \quad 0.336 \quad 0.314-0.650 \quad 0.771-1.181 \quad 0.715-0.915 \quad 0.091-0.207 \quad 0.330-0.503 \quad 0.210 \quad 0.500 \quad 0.345-0.488$ 0.404-0.610 $0.500 \quad 0.000-0.360 \quad 0.000 \quad 0.023-0.366 \quad 0.090-0.740 \quad 0.748-1.414 \quad 0.275-0.8500 .100-0.6150 .403 \quad 0.250 \quad 0.544-0.788$ $\begin{array}{llllllllllll}0.727-0.924 & 0.550-0.744 & 0.382-0.587 & 0.007-0.010 & 0.621-1.000 & 0.333-0.666 & 0.222-0.888 & 0.239 & 0.066 & 0.600 & 0.333\end{array} ?$ ? $\quad 0.9550 .4020 .2770 .2220 .7940 .2030 .4930 .6000 .5000 .5600 .4180 .390$

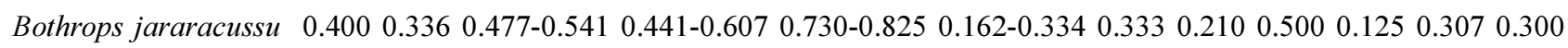
$\begin{array}{llllllllllllllll}0.238-0.622 & 0.000 & 0.333 & 0.145-1.105 & 0.837-1.696 & 0.395 & 0.150 & 0.403 & 0.250 & 0.588 & 0.508-0.764 & 0.525-0.687 & 0.261-0.471 & 0.004\end{array}$ 0.216-0.729 0.095-0.571 $0.4440 .455-0.6230 .4660 .6000 .333$ ? ? ? ? $0.644-0.9110 .241-0.7930 .314-0.5920 .333-$ 0.500 0.800-0.817 0.353-0.495 0.468-0.506 0.579-0.721 0.549-0.784 0.560 0.209 0.390

Bothrops barnetti $0.000 \quad 0.336 \quad 0.460-0.588 \quad 0.524-0.810 \quad 0.648-0.810 \quad 0.029-0.221 \quad 0.221-0.500 \quad 0.210 \quad 0.400-0.850 \quad 0.223-0.338$ $\begin{array}{lllllllllllll}0.372-0.730 & 0.413-0.632 & 0.260-0.766 & 0.000 & 0.083-0.530 & 0.125-0.795 & 0.577-1.340 & 0.285-0.615 & 0.040-0.480 & 0.403 & 0.250 & 0.352\end{array}$ $\begin{array}{lllllllllllll}0.555-0.762 & 0.650-0.941 & 0.500-0.721 & 0.002-0.004 & 0.432-1.054 & 0.142-1.047 & 0.222-1.000 & 0.839 & 0.533 & 0.200 & 0.333\end{array} ?$ ? $\quad 0.7110 .4710 .1850 .3880 .7310 .0350 .6320 .7000 .5000 .8100 .0460 .609$

Bothrops venezuelensis 0.4000 .3360 .8040 .4520 .0000 .0260 .3330 .2100 .5000 .5000 .1530 .6000 .2800 .0000 .0000 .250 0.8960 .3950 .1500 .4030 .2500 .7050 .9090 .8090 .512 ? ? ? ? $0.5990 .4000 .384-0.6160 .083-0.416$ ? ? ? 0.5550 .3790 .5180 .1660 .8170 .3980 .8600 .7000 .7500 .8100 .3020 .125

Bothrops_moojeni $0.400 \quad 0.3360 .656-0.7640 .822-1.2250 .9160 .0260 .3330 .2100 .5000 .3750 .552-0.9860 .6000 .238-0.522$

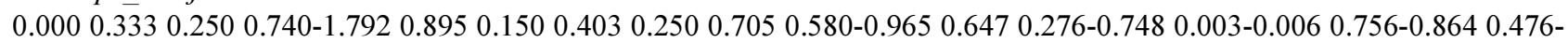
0.6190 .1110 .3590 .133 ? ? ? ? ? ? 0.4660 .7010 .8700 .3880 .8000 .4240 .7591 .0000 .9160 .5600 .5810 .593

Bothrops atrox $\quad 0.036-0.1700 .336 \quad 0.683-0.804 \quad 0.654-0.870 \quad 0.719-0.8910 .026 \quad 0.191-0.3630 .2100 .375-0.8250 .365-0.510$ 0.527-0.652 0.392-0.508 0.044-0.250 $0.000 \quad 0.333 \quad 0.225-0.775 \quad 0.540-1.748 \quad 0.395 \quad 0.150 \quad 0.153-0.486 \quad 0.250 \quad 0.471-0.743 \quad 0.388-$ 0.763 0.336-0.580 0.320-0.593 0.002-0.007 0.432-0.972 0.190-0.619 0.111-0.444 0.450-0.556 0.120-0.466 0.600 0.333? ? ? ? 0.4220 .2410 .4810 .1660 .7650 .1590 .3160 .9000 .7500 .8100 .4650 .593

Bothrops asper $\quad 0.400 \quad 0.3360 .9240 .8810 .8330 .0260 .000 \quad 0.2100 .5000 .2500 .3070 .6000 .2800 .0000 .0000 .2500 .896$

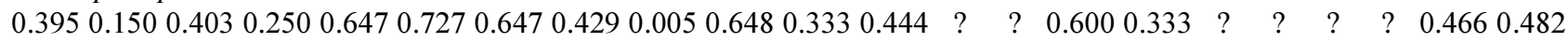
0.5180 .3330 .8450 .5920 .7970 .8000 .8330 .8100 .3020 .640

Bothrops leucurus $0.4000 .3360 .805-0.8800 .631-0.7740 .8330 .0260 .208-0.3750 .2100 .5000 .5000 .489-0.7410 .5000 .138-$

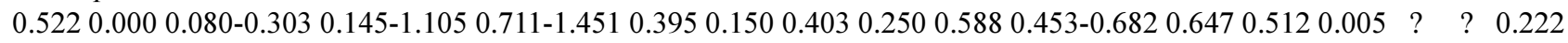
0.4190 .400 ? ? ? ? ? ? 0.4220 .4820 .5180 .5550 .7200 .4420 .7590 .9000 .8330 .560 ? ?

Bothrops lanceolatus 0.6000 .3361 .0010 .7380 .8330 .0260 .3330 .2101 .0000 .3750 .7690 .7000 .2800 .0000 .3330 .7500 .896 0.8950 .6500 .4030 .2500 .5881 .0000 .8091 .012 ? $0.7020 .333 \quad ? \quad 0.7190 .400 \quad$ ? ? ? ? ? ? 0.5550 .5510 .462 $0.5000 .8110 .4600 .3160 .9001 .0000 .810 ?$ ?

\section{$\&[$ num]}

Crotalus durissus ???????00?000000000000000??0000?001000000000000?0?00000000000000[01]1000 Lachesis muta ???????00?00100[01][01]0000000000010002001100011311010100100000100000000001 Bothriechis schlegelii ???????00?101101?010000100000000010????0?????????020010010010000100? Porthidium nasutum ???????00?001100210011100000?10000011100010?0?110?0200100110??1000010 Atropoides nummifer ???????00?00110021100001001011000001200001????????020000010100?0000?1 Cerrophidion godmani ???????00?0011002000?0100000?101000?2??00?????0?0?0??0?????1001?????? Bothrocophias hyoprora ???0???01001111011101110100011?0100000000120000?0?0100110101110101011 Bothrocophias microphthalmus ???0???0100111[01]01010111010001101100000000100000?0?0110111111110101001 Bothrocophias andianus ???0???0000111[01]0?01010100000[01]1[01]1200110001111100?0?0110110111110101011 Bothrops lojanus ???0???0000111[01]0?010[12]01000010[01]0020000[01]000110200?0?01001101111100010?1 Bothrops pictus ???1???10100110[01]??[01]02010000001[01]02001010002001?0?0?001020001111010?0?1 Bothrops ammodytoides ???1???10100110010102111001[01]01002001001112100[01]11120[12]1011001111100?[01]?1 Bothrops jonathani ???2???20202110021[01][01]2011001[01]01[01]020010011122111101101000[01]01000110010?1 Bothrops alternatus ???2???202021100[12][01]012011001001[01]02001001112211110110000?0?10001100???0 Bothrops cotiara ???[01]???20202110010012011001001[01]020010011122021101100100001001110110?1 Bothrops fonsecai ???[01]???20202110010012011001001[01]020010011122001101100100101111110111?1 Bothrops itapetiningae ???2???2020211001001201100100100200120111220??0?0?01?0011101??10010?0 Bothrops sonene sp. nov. 11002120030011001000201100100100200111121120100?0?0??0?????????????? Bothrops cf. sonene 11002120030011001000201100100100200??????????????????????????????? Bothrops mattogrossensis 110011000300110010002011001001[01]0200111121????????0????????????????? Bothrops aff. mattogrossensis_1 1[12][01]011000300110010002011001001[01]02001111211201?1?1?1????????????????? Bothrops aff. mattogrossensis_2 1[12]0011000300110010002011001001[01]0200111121120000?0?0???????????????? Bothrops_aff_mattogrossensis_3 1[12][01]011000300110010002011001001[01]0200111121120001?1?1?????????????????? Bothrops diporus 13202[01]100300110010002011001001[01]0200111121120110?0?0110011110121001011 Bothrops aff. diporus 14202[01]100300110010002011001001[01]02001111211201?0?0?011001111011??01011 
Bothrops aff. pubescens 1[23]102010030011001[01]002011001001[01]0200111121?????????0?????????????????? Bothrops pubescens 121010100300110010002011001001[01]0200111121110100?0?0010111100111011011 Bothrops neuwiedi 11102[01]10030011001[01]002011001001[01]020011112112001????0???????????????? Bothrops aff. neuwiedi 111021[01]00300110010002011001001[01]0200111121?????????0???????????????? Bothrops marmoratus 120011000300110010002011001001[01][01]200111121?????????0???????????????? Bothrops pauloensis 1[12]0011000300110010002011001001[01]0200111121????????0??????????????? Bothrops erythromelas 0??000000300110010002011001001[01][01]200111121120100?0?0?????????????????? Bothrops lutzi [01]0001100030011001000201100100100200111121100110?0?0?????????????????? Bothrops jararaca ???0???004001101??002011001001002001110011?0?00?0?00000101001200010?1 Bothrops insularis ???0???004001101??002011001001002001110011?0?00?0?00000101001200010?1 Bothrops taeniatus ???0???005101101??00201101[01]00100210101000211100?0?00000011101210010?? Bothrops pulchra ???0???005101101??00201101[01]00100210????0????????????0??????????????? Bothrops chloromelas ???0???005101101??00201101[01]001[01]1110101000100100?0?000010111?32?00?0?1 Bothrops oligolepis ???0???005101101??00201101[01]001[01]0110????0??????????010101?0032000?0?1 Bothrops bilineatus ???0???005101101??00201101[01]0010021010100100???0?0?00100001103?000?0?1 Bothrops sanctaecrucis ???0???006001101??00201101[01]001[01]0200111001100000?0?10101001101[12]00[01]?0?1 Bothrops brazili ???0???006001101??00201[01]01[01]001[01]1200111001100000?0?1010?0111012?11?0?1 Bothrops jararacussu ???0???006001101??00201[01]01[01]001[01]0200111000100000?0?10000001001201[01]10?1 Bothrops barnetti ???0???007001101??002011001001[01][01]200120001231100?0?00100101002101010?1 Bothrops venezuelensis ???0???007001101??00201100100101200111001200000?0?000010010012010?0?? Bothrops moojeni ???0???007001101??00201102100100200121001200110?0?00000001101200010?1 Bothrops atrox ???0???007001101??002011021001[01]0200121001200000?0?00000001001201010?1 Bothrops asper ???0???007001101??00201102100100200121001100100?0?01000001001200010?? Bothrops leucurus ???0???007001101??0020110210010020012100110??10?0?00000001001210010?1 Bothrops lanceolatus ???0???007001101??00201100000101200111000200000?0?00000001101200??0?? 


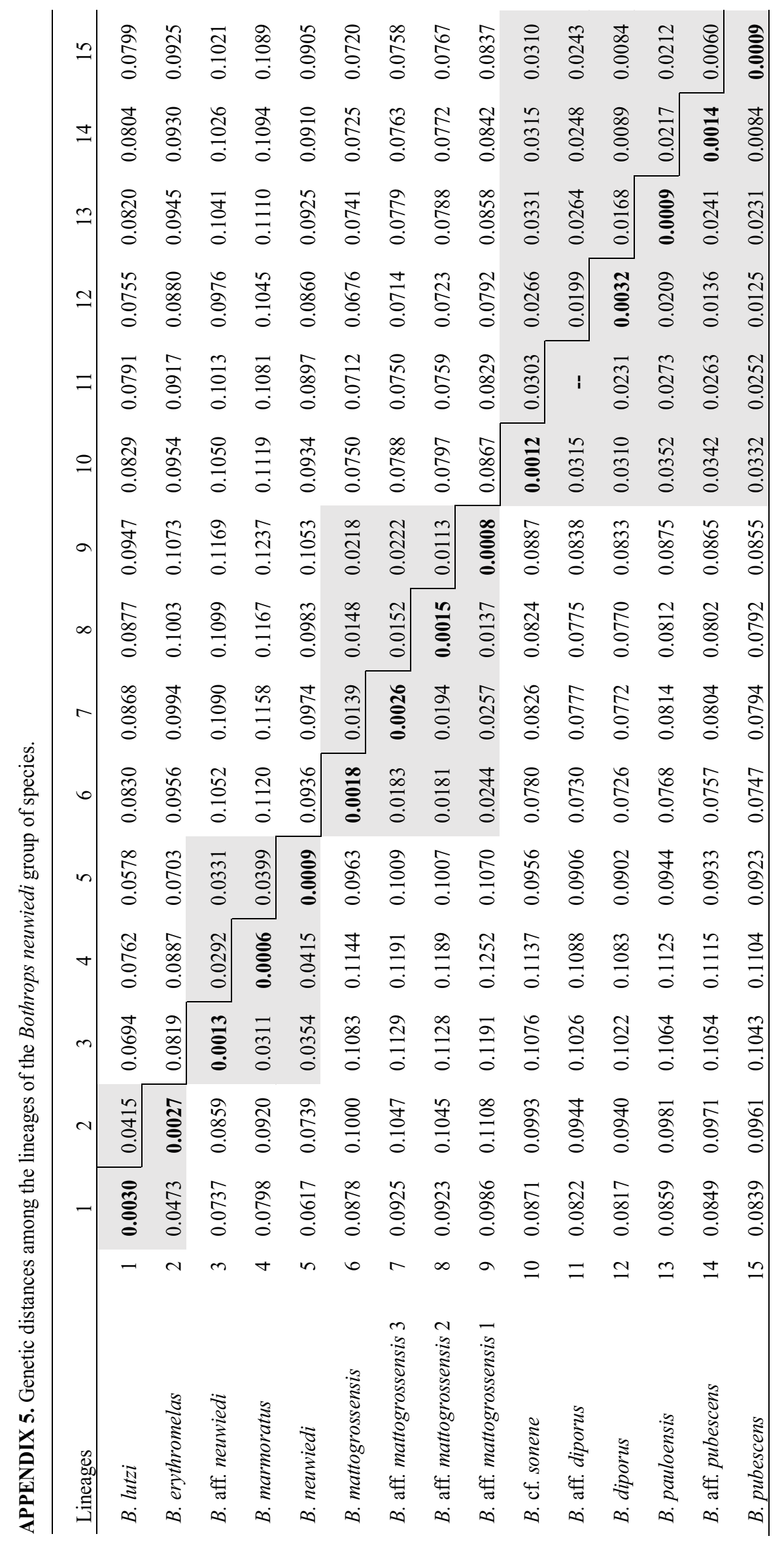


APPENDIX 6. Single cladogram obtained in the parsimony analysis of molecular data-only, under implied weighting $(\mathrm{k}=11$; same topology obtained under $\mathrm{k}=8-9,12-15)$. Length: 3711. Fit: 141.001. Above and below nodes, jackknife and bootstrap proportions respectively.

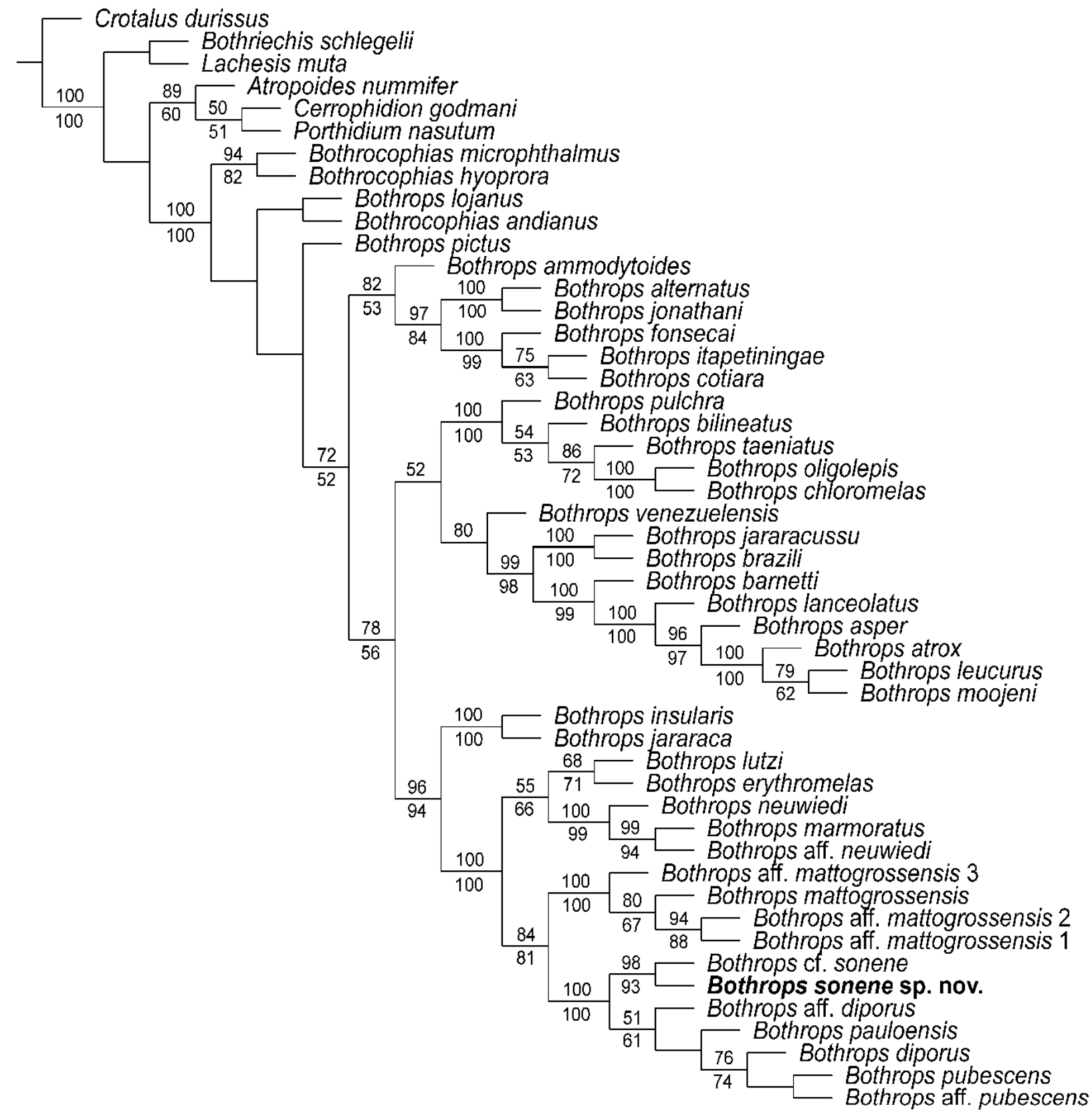


APPENDIX 7. Single cladogram obtained in the parsimony analysis of morphological data-only, under implied weighting $(\mathrm{k}=3$; same topology obtained under $\mathrm{k}=4-5)$. Length: 410.765. Fit $=40.491$. Above and below nodes, jackknife and bootstrap proportions respectively.

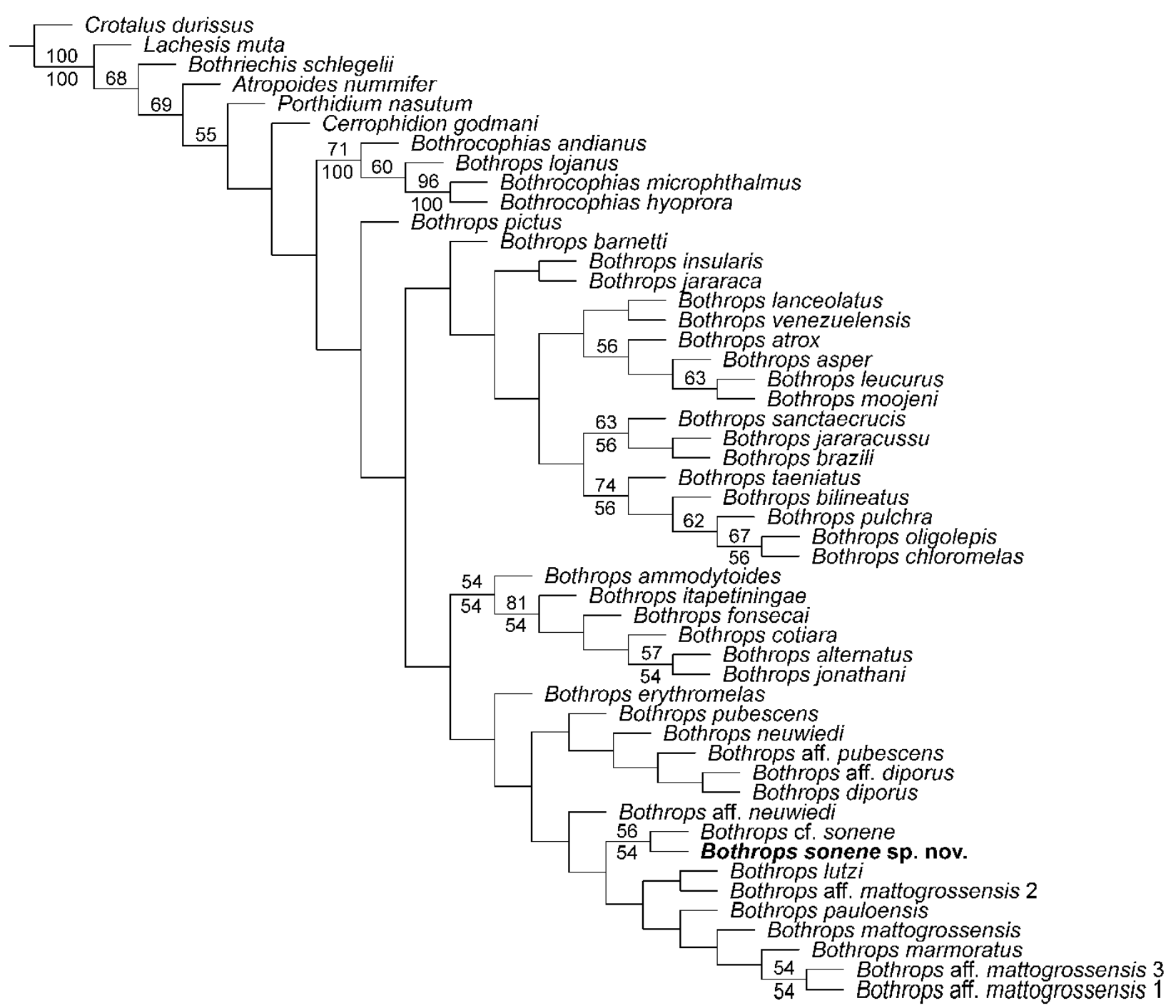

